\title{
A Summary of Water-Quality Monitoring in San Francisco Bay in Water Year 2017
}

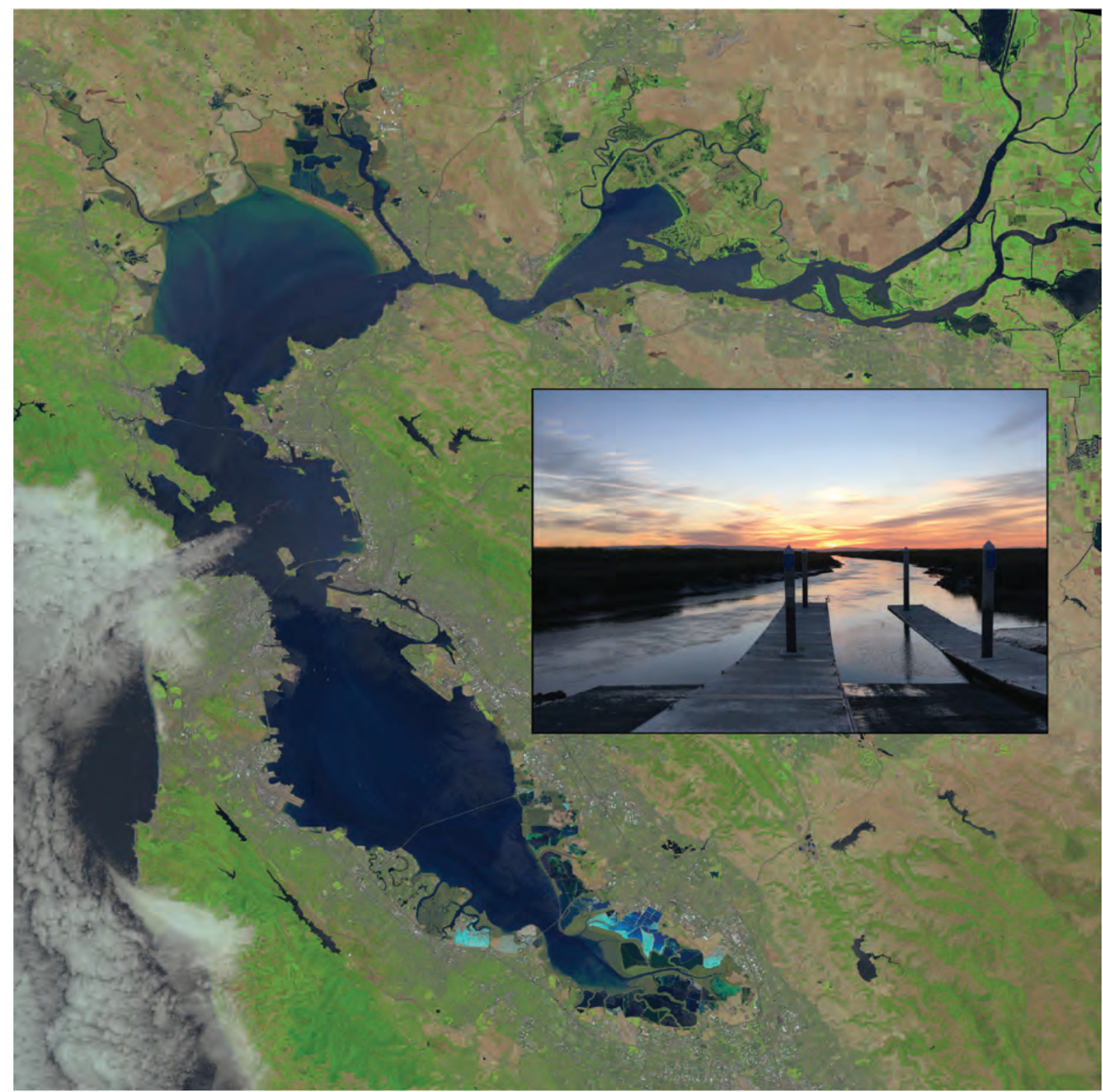

Scientific Investigations Report 2020-5064 
Cover photo: Remote-sensing image from May 10, 2006, Landsat 8 OLI/TIRS Collection 1 , U.S. Geological Survey Earth Resources Observation and Science Center, Sioux Falls, S.D.

Inset photo: Alviso Slough in Lower South Bay, at $\sim 37^{\circ} 25^{\prime} 45.22^{\prime \prime} \mathrm{N}, 121^{\circ} 58^{\prime} 53.40^{\prime \prime}$, looking North 60 degrees to the West. Photograph taken by Darin Einhell, October 3, 2019. 


\section{A Summary of Water-Quality Monitoring in San Francisco Bay in Water Year 2017}

By Daniel Livsey and Maureen Downing-Kunz

Scientific Investigations Report 2020-5064 


\title{
U.S. Department of the Interior \\ DAVID BERNHARDT, Secretary
}

\author{
U.S. Geological Survey \\ James F. Reilly II, Director
}

U.S. Geological Survey, Reston, Virginia: 2020

For more information on the USGS - the Federal source for science about the Earth, its natural and living resources, natural hazards, and the environment—visit https://www.usgs.gov or call 1-888-ASK-USGS.

For an overview of USGS information products, including maps, imagery, and publications, visit https://store.usgs.gov/.

Any use of trade, firm, or product names is for descriptive purposes only and does not imply endorsement by the U.S. Government.

Although this information product, for the most part, is in the public domain, it also may contain copyrighted materials as noted in the text. Permission to reproduce copyrighted items must be secured from the copyright owner.

Suggested citation:

Livsey, D., and Downing-Kunz, M., 2020, A summary of water-quality monitoring in San Francisco Bay in water year 2017: U.S. Geological Survey Scientific Investigations Report 2020-5064, 78 p., https://doi.org/10.3133/sir20205064.

Associated data for this publication:

U.S. Geological Survey, 2019, National Water Information System: U.S. Geological Survey Web interface, https://doi.org/10.5066/F7P55KJN.

ISSN 2328-0328 (online) 


\section{Acknowledgments}

Funding for this work was provided in part by the U.S. Army Corps of Engineers and Regional Monitoring Program for San Francisco Bay, the California Department of Water Resources, the Bureau of Reclamation, and U.S. Geological Survey Priority Ecosystems Studies Program.

Thanks to Paul Buchanan, Gwen Davies, Darin Einhell, and David Schoellhamer for assistance with data collection and analysis. 


\section{Contents}

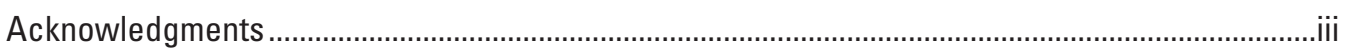

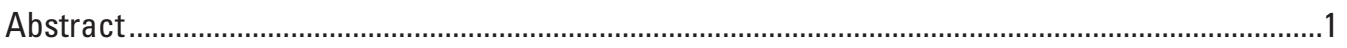

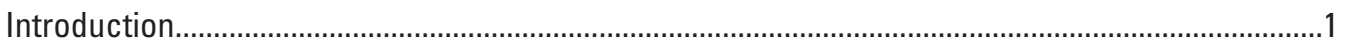

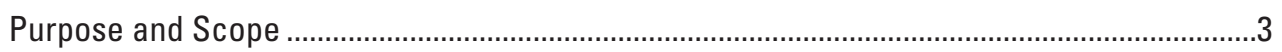

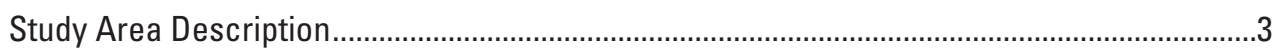

Methods

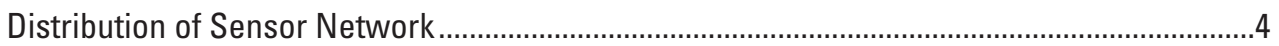

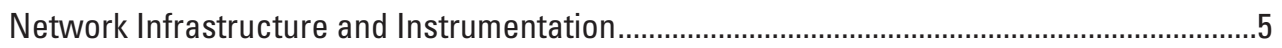

Network Maintenance and Sample Collection..........................................................................

Water-Quality Data Review and Publication .............................................................................

Estimation of Suspended-Sediment Concentration ................................................................

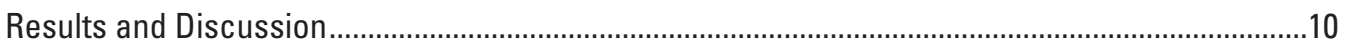

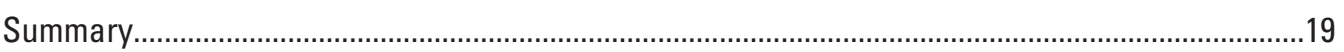

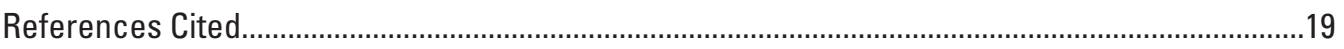

Appendix 1 Model Archive Summaries for Suspended-Sediment Concentrations at San

Francisco Bay Monitoring Stations, Water Year 2017 ..........................................................21

\section{Figures}

1. Map showing the San Francisco Bay with locations of continuous monitoring stations in operation in 2017 and former stations

2. Schematic of typical monitoring station, San Francisco Bay area, California...................6

3. Photographs showing deployment at Alcatraz Island in Central Bay, copper carriage to protect instrumentation from debris and reduce biological growth on instrument, and Van Dorn-style 2.2-L water sampler used to collect discrete water samples for subsequent suspended-sediment concentration analysis

4. Graphs showing statistical assessment of different regression models relating turbidity to suspended-sediment concentration at Benicia Bridge in Suisun Bay, Calif., for water year 2017.

5. Box-and-whisker plots showing distribution and variability of water-quality parameters at Mallard Island in Suisun Bay, Calif., by water year from 1995 to 2015 ....11

6. Box-and-whisker plots showing distribution and variability of water-quality parameters at Benicia Bridge in Suisun Bay, Calif., by water year from 1997 to 2015 ...12

7. Box-and-whisker plots showing distribution and variability of water-quality parameters at Carquinez Bridge in Carquinez Strait, Calif., by water year from 2000 to 2017

8. Box-and-whisker plots showing distribution and variability of water-quality parameters at Richmond-San Rafael Bridge in San Pablo Bay, Calif., by water year from 2007 to 2017

9. Box-and-whisker plots showing distribution and variability of water-quality parameters at Alcatraz Island in Central San Francisco Bay, Calif., by water year from 2004 to 2017

10. Box-and-whisker plots showing distribution and variability of water-quality parameters at Pier 17 in Central San Francisco Bay, Calif., by water year from 2015 to 2017 
11. Box-and-whisker plots showing distribution and variability of water-quality parameters at San Mateo Bridge in South San Franciscso Bay, Calif., by water year from 1991 to 2017

12. Box-and-whisker plots showing distribution and variability of water-quality parameters at Dumbarton Bridge in South San Francisco Bay, Calif., by water year from 1993 to 2017

\section{Tables}

1. Water-quality monitoring stations and sensors in operation in 2017, San Francisco Bay area, California 4

2. Sampling schedule for sensor network, 2017, San Francisco Bay area, California..........5

\section{Conversion Factors}

International System of Units to U.S. customary units

\begin{tabular}{|c|c|c|}
\hline Multiply & By & To obtain \\
\hline \multicolumn{3}{|c|}{ Length } \\
\hline micrometer $(\mu \mathrm{m})$ & $3.937 \mathrm{e}-5$ & inch (in) \\
\hline centimeter $(\mathrm{cm})$ & 0.394 & inch (in) \\
\hline meter $(\mathrm{m})$ & 3.291 & foot $(\mathrm{ft})$ \\
\hline kilometer (km) & 0.622 & mile (mi) \\
\hline \multicolumn{3}{|c|}{ Velocity } \\
\hline Meters per second $(\mathrm{m} / \mathrm{s})$ & 3.281 & feet per second $(\mathrm{ft} / \mathrm{s})$ \\
\hline \multicolumn{3}{|c|}{ Area } \\
\hline square kilometer $\left(\mathrm{km}^{2}\right)$ & 0.3861 & square mile $\left(\mathrm{mi}^{2}\right)$ \\
\hline \multicolumn{3}{|c|}{ Volume } \\
\hline liter $(\mathrm{L})$ & 0.264 & gallon (gal) \\
\hline cubic kilometers $\left(\mathrm{km}^{3}\right)$ & $8.104 \mathrm{e} 5$ & acre-feet (ac-ft) \\
\hline \multicolumn{3}{|c|}{ Weight and mass } \\
\hline kilogram (kg) & 2.203 & pounds (lb) \\
\hline
\end{tabular}

Temperature in degrees Celsius $\left({ }^{\circ} \mathrm{C}\right)$ may be converted to degrees Fahrenheit $\left({ }^{\circ} \mathrm{F}\right)$ as follows:

$$
{ }^{\circ} \mathrm{F}=\left(1.8 \times{ }^{\circ} \mathrm{C}\right)+32 .
$$

Temperature in degrees Fahrenheit $\left({ }^{\circ} \mathrm{F}\right)$ may be converted to degrees Celsius $\left({ }^{\circ} \mathrm{C}\right)$ as follows:

$$
{ }^{\circ} \mathrm{C}=\left({ }^{\circ} \mathrm{F}-32\right) / 1.8 \text {. }
$$




\section{Abbreviations}

NWIS National Water Information System

SFB San Francisco Bay

SSC Suspended-sediment concentration

USGS U.S. Geological Survey

WY Water Year (October 1 of the previous calendar year to September 30) 


\title{
A Summary of Water-Quality Monitoring in San Francisco Bay in Water Year 2017
}

\author{
By Daniel Livsey and Maureen Downing-Kunz
}

\section{Abstract}

This report summarizes the activities of the U.S. Geological Survey (USGS) San Francisco Bay Water-Quality Monitoring and Sediment Transport Project during water year 2017, including an explanation of methods employed, stations operated, and a graphical summary of data for the period of record for stations operational in water year 2017. In cooperation with partner agencies, the USGS maintains a network of sensors that continuously and autonomously measures water-quality parameters in San Francisco Bay including water temperature, specific conductance, turbidity, and suspended-sediment concentration. Data are collected at several locations in the estuary by a network of water-quality sondes sampled at 15-minute intervals. Methods of data collection are presented along with documentation of the regression models utilized to estimate suspended-sediment concentration from observed turbidity, a commonly utilized surrogate to estimate suspended-sediment concentration. The goals of the data collection effort are to (1) obtain long-term, high-frequency, and high-quality data to describe San Francisco Bay water quality; (2) make the data publicly available on the USGS National Water Information System data portal; and (3) help improve understanding of the spatial and temporal variability of water quality in the estuary, informing management decisions regarding restoration, water supply, navigation, and ecology.

\section{Introduction}

San Francisco Bay (SFB) is the largest estuary on the west coast of the contiguous United States covering approximately 1,425 square kilometers $\left(\mathrm{km}^{2}\right)$. Two major rivers, the Sacramento and San Joaquin Rivers converge at the landward extent of the SFB, forming the SacramentoSan Joaquin Delta. The Sacramento and San Joaquin Rivers together drain approximately 40 percent of California's land area. The estuary, spanning the SFB and the Sacramento-San Joaquin Delta, hosts many species of marine and terrestrial flora and fauna, and the surrounding urbanized area is home to over 7 million people (fig. 1; State of California, 2018).

Infrastructure in the estuary and ecosystem services provided by the estuary, such as shipping harbors, recreation, tourism, and fishing, contribute billions of dollars to the local economy (Barnard and others, 2013). These services and local ecology are directly affected by water quality that is influenced by numerous anthropogenic and climate-related factors. Over the past 200 years, the estuary has been altered by human activities including aggradation of sediment produced by hydraulic mining of the California Gold Rush era (1853-1883), channel dredging, construction of dams, wetland loss, industrial salt production, municipal and industrial wastewater effluent, freshwater diversions (Schoellhamer, 2011; Cloern and Jassby, 2012; Barnard and others 2013), ongoing urban development, water use, industrial practices, and changes in climate, all of which affect water quality in the estuary at many spatial and temporal scales. Observations can improve our understanding of the spatial and temporal variability in water quality throughout the estuary, and continuous, long-term water-quality monitoring provides information necessary to support resource-management decisions.

To further understand water quality in SFB, the U.S. Geological Survey (USGS) in cooperation with partner agencies has operated a water-quality monitoring network to continuously measure water-quality parameters including water temperature, conductivity (related to specific conductance and salinity), turbidity, and suspended-sediment concentration (SSC) in the estuary since 1989. The goals of the data collection effort are to (1) obtain long-term, high-frequency, and high-quality data to describe San Francisco Bay water quality; (2) make the data publicly available on the USGS National Water Information System (NWIS) data portal; and (3) help improve understanding of the spatial and temporal variability of water quality in the estuary.

Water temperature, specific conductance, turbidity, and $\mathrm{SSC}$ are fundamental water-quality parameters for estuaries, which are transition zones between the ocean and watersheds (Geyer and MacCready, 2014). Specific conductance, a measure of salinity, is the conductivity of water compensated to a reference water temperature at 25 degrees Celsius $\left({ }^{\circ} \mathrm{C}\right)$. 


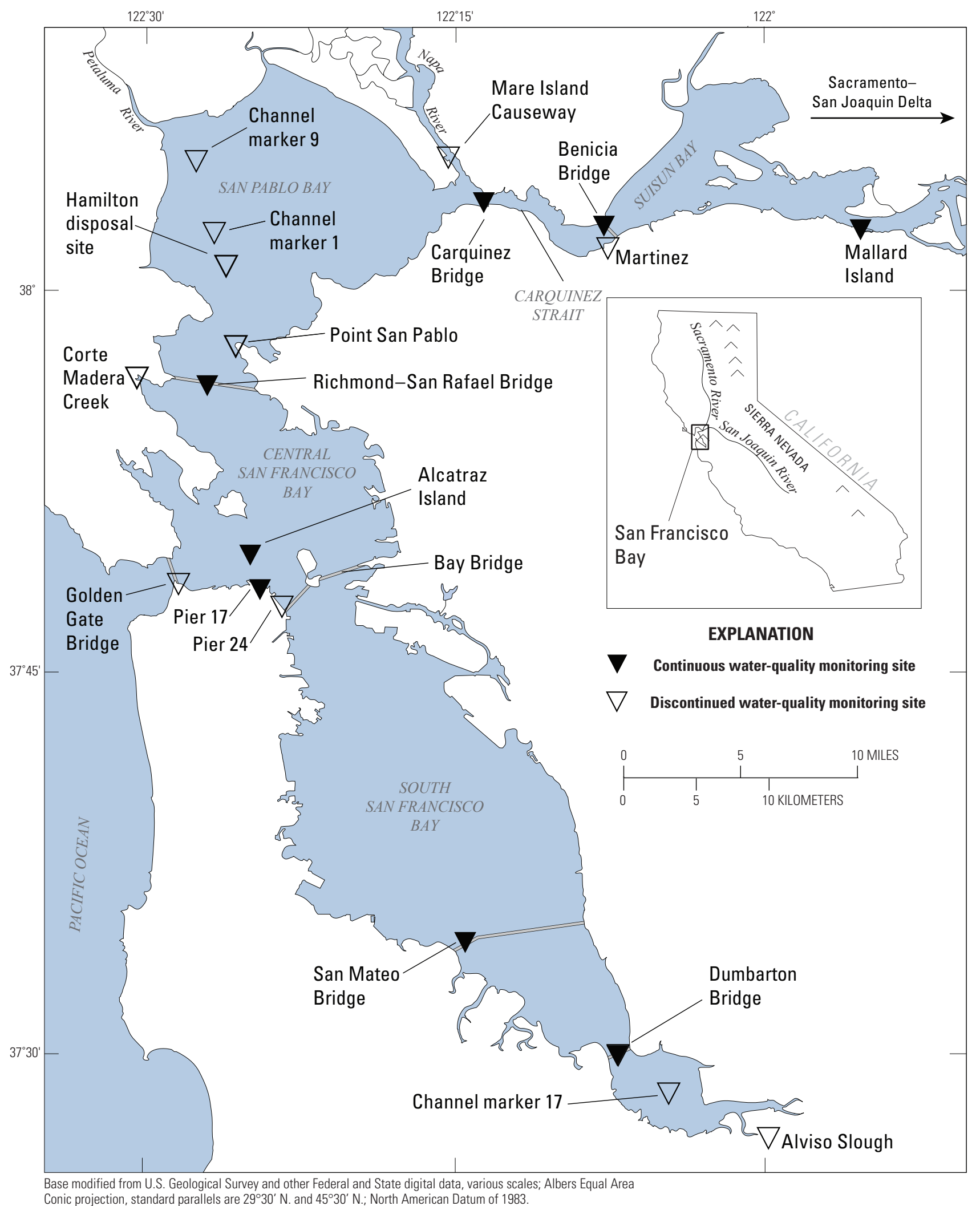

Figure 1. San Francisco Bay and locations of continuous monitoring stations in operation in 2017 and prior to 2017. 
Water temperature, specific conductance, and turbidity can be continuously measured by water-quality sensors, but continuous estimates of SSC must be estimated by regression from surrogate measurements (Rasmussen and others, 2009). Continuous sampling for SSC is not yet feasible because direct measurement of SSC requires laboratory analysis of water samples, which is labor intensive and cost prohibitive. Although SSC could not be measured continuously, continuous estimates of SSC can be obtained by developing regression models that statistically relate continuous turbidity measurements to discrete SSC measurements analyzed from water samples (Rasmussen and others, 2009). Turbidity is a useful surrogate for SSC because turbidity is primarily controlled by changes in SSC (Downing, 2006).

Conductivity and water temperature are primary factors affecting water density; water density affects the mixing of different water masses both in vertical and horizontal dimensions (Geyer and MacCready, 2014). Turbidity, a measure of water clarity (Anderson, 2005), is a measure of light availability in the water column, one of the controls on primary production in the estuary (Cloern and Jassby, 2012).

The SSC, estimated by regression from turbidity, is important to quantify because suspended sediment influences availability of light in the water column and can be associated with organic matter, nutrients, and contaminants such as mercury. The concentration of suspended sediment is also important to quantify because the concentration of sediment influences sediment deposition in the estuary, which augments shorelines and mudflats in nearshore regions and, in deeper waters, can impede ship navigation. Suspended sediments are transported throughout the estuary by river flow, tidal currents, and wind waves (for example, Schoellhamer and others, 2018).

\section{Purpose and Scope}

This report summarizes data-collection activities for the USGS SFB Water-Quality Monitoring and Sediment Transport Project in water year (WY) 2017 and presents the regression models used to relate turbidity to SSC. A WY begins October 1st of the previous calendar year and ends September 30th of the named water year. Station locations and water-quality parameters have changed since monitoring began in 1989; this report describes present operations only. Readers are referred to previously published reports detailing past operations (Buchanan and Ganju, 2004; Buchanan and others, 2014, 2018).

\section{Study Area Description}

The SFB comprises four sub-embayments, including Suisun Bay, San Pablo Bay, central SFB, and south SFB (Barnard and others, 2013; fig. 1). The bathymetry of the SFB is characterized by broad, shallow mudflats at water depths less than 5 meters $(\mathrm{m})$ relative to mean lower low water (MLLW) incised by a deeper, central channel where water depths range between 10 and $25 \mathrm{~m}$ MLLW (Barnard and others, 2013). Saline water enters the SFB from the Pacific Ocean, while freshwater from the Sacramento-San Joaquin Delta, the estuary's primary source of freshwater (93 percent of total; McKee and others, 2013), enters through Suisun Bay. Saline water from the Pacific Ocean enters the central bay through a single inlet, the Golden Gate Strait at the Golden Gate Bridge (fig. 1), which is around $1.5 \mathrm{~km}$ wide and $100 \mathrm{~m}$ deep; this large cross section, coupled with the semidiurnal tide and a tidal range of around $2 \mathrm{~m}$ (Barnard and others, 2013), leads to a volume of ocean-water exchange on the tidal time scale that far exceeds the volume of freshwater entering from the Sacramento-San Joaquin Delta at the seasonal time scale.

Ocean water outside the SFB has salinities near 33 practical salinity units and specific conductance values greater than 53,000 microsiemens per centimeter $(\mu \mathrm{s} / \mathrm{cm})$ at $25^{\circ} \mathrm{C}$. Ocean water outside the SFB generally exhibits lower turbidity (and hence lower SSC) than freshwater. Freshwater runoff from the watershed has lower salinity and specific conductance (near 0 and less than $200 \mu \mathrm{s} / \mathrm{cm}$ at $25^{\circ} \mathrm{C}$, respectively) than ocean water and is generally more turbid (higher SSC). Depending on the season, freshwater inflow to the SFB can be cooler (for example, during winter and spring) or warmer (summer and fall) than ocean water.

Water currents in the SFB are primarily driven by tides and waves induced by onshore diurnal winds (Barnard and others, 2013). The tidal forcing induces water velocities ranging from 0.2 meter per second $(\mathrm{m} / \mathrm{s})$ in shallow water to more than $1.0 \mathrm{~m} / \mathrm{s}$ in deep channels (Cheng and Gartner, 1984; Smith, 1987). Onshore diurnal winds drive wind waves that interact with tidal currents to affect circulation and sediment transport over the mudflats (Brand and others, 2010). Winds generally increase during spring and summer months (MarchJuly) and decrease in fall and winter (Sept.-Feb.; Brand and others, 2010).

Rainfall and freshwater inflow into SFB follow a seasonal pattern with a wet season from October to April and relatively dry season from May to September (McKee and others, 2013). Freshwater discharge to the SFB from the Sacramento-San Joaquin Delta is greatest in the spring months (March to May) because of snowmelt in the Sierra Nevada (McKee and others, 2006). 
The volume and sources of suspended sediment in the SFB have changed during the past 200 years as a result of hydraulic mining, aggregate mining, channel dredging, construction of dams, wetland loss, industrial salt pond construction, municipal and industrial waste-water effluent, and freshwater diversions (Schoellhamer, 2011; Cloern and Jassby, 2012; Barnard and others, 2013). Today, although the Sacramento-San Joaquin Delta provides over 90 percent of the freshwater discharge to the SFB, local tributaries adjacent to the SFB provide roughly 60 percent of sediment discharged to the estuary (McKee and others, 2013). The channel-bottom sediment in south SFB and in shallow areas of central SFB, San Pablo Bay, and Suisun Bay is composed of smaller diameter silts and clays (Buchanan and Ganju, 2004), whereas in deeper regions of Central Bay and in Carquinez Strait, the channel bottom is composed of larger diameter silts and sands (Conomos and Peterson, 1977).

\section{Methods}

\section{Distribution of Sensor Network}

The eight monitoring stations in operation in 2017 are distributed spatially across SFB (fig. 1). Instrumentation measured parameters at each station in the network are summarized in table 1 . The sampling schedule for the sensor network is provided in table 2. The eight stations are described from north to south: Mallard Island and Benicia Bridge are at the landward and seaward extent of Suisun Bay, respectively. The station at Carquinez Bridge is in Carquinez Strait between San Pablo Bay and Suisun Bay. The station at Richmond-San Rafael Bridge is near the transition from San Pablo Bay to central SFB. The stations at Alcatraz Island and Pier 17 characterize water quality near the Pacific Ocean inlet in central SFB. The station at San Mateo Bridge is near the middle of south SFB. The station at Dumbarton Bridge is at Dumbarton Narrows between south SFB and lower south SFB, the most landward sub-embayment of south SFB.

Table 1. Water-quality monitoring stations and sensors in operation in water year 2017, San Francisco Bay area, California.

[See figure 1 for station locations. Sensor position refers to elevation of sensors in the water column for stations equipped with two instruments. Station water depths are reported relative to the bed and to mean lower low water. Abbreviations: m, meter. Water-quality parameters: Tu, turbidity; $\mathrm{SSC}$, suspended-sediment concentration; $\mathrm{C}$, specific conductance; $\mathrm{T}$, water temperature; - , no data]

\begin{tabular}{|c|c|c|c|c|c|c|}
\hline Station name and number & $\begin{array}{l}\text { Water depth in } \\
\text { meters below } \\
\text { mean lower low } \\
\text { water }^{3}\end{array}$ & $\begin{array}{l}\text { Sensor } \\
\text { position }\end{array}$ & $\begin{array}{l}\text { Sensor elevation } \\
\text { above bottom } \\
\text { (m) }\end{array}$ & $\begin{array}{l}\text { Sensor depth from mean } \\
\text { lower low water } \\
\text { (m) }\end{array}$ & $\begin{array}{l}\text { Observed } \\
\text { water- } \\
\text { quality } \\
\text { parameters }\end{array}$ & $\begin{array}{c}\text { Year } \\
\text { monitoring } \\
\text { began }\end{array}$ \\
\hline \multirow[t]{2}{*}{ Suisun Bay at Mallard Island 11185185} & \multirow[t]{2}{*}{7.6} & Upper & \multicolumn{2}{|c|}{ Deployed on a float $1 \mathrm{~m}$ below water surface } & \multirow[t]{2}{*}{$\mathrm{Tu}, \mathrm{SSC}$} & \multirow[t]{2}{*}{1994} \\
\hline & & Lower & 1.5 & 6.1 & & \\
\hline \multirow{2}{*}{$\begin{array}{l}\text { Suisun Bay at Benicia Bridge } \\
\quad 11455780\end{array}$} & \multirow[t]{2}{*}{24.4} & Upper & 22 & 2.4 & \multirow{2}{*}{$\begin{array}{l}\mathrm{C}, \mathrm{T}, \mathrm{Tu} \\
\mathrm{SSC}\end{array}$} & \multirow[t]{2}{*}{2001} \\
\hline & & Lower & 5.8 & 18.6 & & \\
\hline \multirow{2}{*}{$\begin{array}{l}\text { Carquinez Strait at Carquinez Bridge }{ }^{1} \\
\quad 11455820\end{array}$} & \multirow[t]{2}{*}{23.8} & Upper & 14.6 & 9.2 & \multirow[t]{2}{*}{$\mathrm{C}, \mathrm{T}$} & \multirow[t]{2}{*}{1999} \\
\hline & & Lower & 1.5 & 22.3 & & \\
\hline \multirow{2}{*}{$\begin{array}{l}\text { San Francisco Bay at Richmond/San } \\
\text { Rafael Bridge } 375607122264701\end{array}$} & \multirow[t]{2}{*}{13.7} & Upper & 9.1 & 4.6 & \multirow{2}{*}{$\begin{array}{l}\text { C, T, Tu, } \\
\text { SSC }\end{array}$} & \multirow[t]{2}{*}{2006} \\
\hline & & Lower & 1.5 & 12.2 & & \\
\hline $\begin{array}{l}\text { San Francisco Bay at Alcatraz Island } \\
374938122251801\end{array}$ & 4.9 & - & 3.3 & 1.6 & $\begin{array}{l}\mathrm{C}, \mathrm{T}, \mathrm{Tu} \\
\text { SSC }\end{array}$ & 2003 \\
\hline $\begin{array}{l}\text { San Francisco Bay at Pier } 17 \\
374811122235001\end{array}$ & 4.9 & - & 1.2 & 3.7 & $\begin{array}{l}\mathrm{C}, \mathrm{T}, \mathrm{Tu} \\
\text { SSC }\end{array}$ & 2013 \\
\hline \multirow{2}{*}{$\begin{array}{l}\text { San Francisco Bay at San Mateo } \\
\text { Bridge near Foster City } 11162765\end{array}$} & \multirow[t]{2}{*}{14.6} & Upper & 13.4 & 1.2 & \multirow[t]{2}{*}{$\mathrm{C}, \mathrm{T}$} & \multirow[t]{2}{*}{1990} \\
\hline & & Lower & 3.0 & 11.6 & & \\
\hline \multirow{2}{*}{$\begin{array}{l}\text { South San Francisco Bay at Dumbarton } \\
\text { Bridge }^{2} 373015122071000\end{array}$} & \multirow[t]{2}{*}{13.7} & Upper & 7.6 & 6.1 & \multirow{2}{*}{$\begin{array}{l}\mathrm{C}, \mathrm{T}, \mathrm{Tu} \\
\text { SSC }\end{array}$} & \multirow[t]{2}{*}{2010} \\
\hline & & Lower & 1.2 & 12.5 & & \\
\hline
\end{tabular}

${ }^{1}$ Station temporarily discontinued during bridge construction June 10, 2012-April 23, 2014.

${ }^{2}$ Station temporarily discontinued during bridge construction October 1, 2011-March 16, 2013.

3Estimated from the National Oceanic and Atmospheric Administration Nautical Chart Catalog during the 1983-2001 National Tidal Datum Epoch from https://www.charts.noaa.gov/ChartCatalog/MapSelect.html. 
Table 2. Sampling schedule for sensor network, water year 2017, San Francisco Bay area, California.

$[\mathrm{Hz}$, hertz $]$

\begin{tabular}{lcccc}
\hline \multicolumn{1}{c}{ Instrument } & $\begin{array}{c}\text { Reported } \\
\text { time series } \\
\text { (minutes) }\end{array}$ & $\begin{array}{c}\text { Sampling } \\
\text { interval } \\
\text { (minutes) }\end{array}$ & $\begin{array}{c}\text { Burst } \\
\text { length } \\
\text { (seconds) }\end{array}$ & $\begin{array}{c}\text { Sampling } \\
\text { frequency } \\
\text { (Hz) }\end{array}$ \\
\hline YSI, Inc., model 6920 multiparameter water-quality sonde & 15 & 15 & 12 & 2 \\
Forest Technology Systems model DTS-12 turbidity sensor ${ }^{1}$ & 15 & 25 & 5 & 20 \\
\hline
\end{tabular}

${ }^{1}$ Used only at Mallard Island in Suisun Bay.

2Reported 15 minute time series is the average of three prior samples collected at 5-minute intervals. Sampling schedule from prior study. Schedule modified to follow YSI sampling schedule in WY 2019.

\section{Network Infrastructure and Instrumentation}

Six of the eight stations (Mallard Island, Benicia Bridge, Carquinez Bridge, Richmond-San Rafael Bridge, San Mateo Bridge, and Dumbarton Bridge, table 1) have instrumentation deployed at two depths in the water column to provide information about vertical variations in water quality. These six stations have sensors at two vertical positions (fig. 2): near the bed (termed, "lower," table 1) and in the upper water column (termed, "upper," table 1). Water depths at the remaining two stations (Pier 17 and Alcatraz Island, table 1) are relatively shallow (5-10 meters), and only one instrument is deployed at each. Instruments are deployed in custom copper carriages suspended in the water column on stainless-steel cables deployed from a davit above the water surface and anchored to the bed using weight plates (figs. 2, $3 B$ ). The metal carriage housing protects the instrumentation from debris, and copper impedes the biological growth that can corrupt data (Borkow and Gabbay, 2009). All deployments are fixed to structures such as bridge piers or boat docks. Six of the eight stations (Benicia Bridge, Carquinez Bridge, Alcatraz Island, Richmond-San Rafael Bridge, San Mateo Bridge, and Dumbarton Bridge, table 1) are accessed by watercraft; the remaining two (Mallard Island and Pier 17, table 1) are accessed from shore. All stations are equipped for data telemetry including datalogger, modem, antenna, and power supply. Data were transmitted hourly by cellular telemetry to a publicly accessible USGS database (National Water Information System, https://waterdata.usgs.gov/nwis; U.S. Geological Survey, 2019).

Observations of water temperature, specific conductance, and turbidity were collected every 15 minutes (table 2). Seven of the stations (Benicia Bridge, Carquinez Bridge, RichmondSan Rafael Bridge, Alcatraz Island, Pier 17, San Mateo Bridge, and Dumbarton Bridge, table 1) use multiparameter water-quality sondes (model 6920, YSI, Inc., Yellow Springs, Ohio); at these stations, specific conductance (reported in $\mu \mathrm{S} / \mathrm{cm}$, at $25^{\circ} \mathrm{C}$ ) and water temperature (reported in ${ }^{\circ} \mathrm{C}$ ) were measured using a combination conductivity and temperature sensor (model 6560, YSI, Inc., Yellow Springs, Ohio). At five of these seven stations (Benicia Bridge, Richmond-San Rafael
Bridge, Alcatraz Island, Pier 17, and Dumbarton Bridge, table 1), turbidity was measured using an optical turbidity sensor (model 6136, YSI, Inc., Yellow Springs, Ohio). At the eighth station (Mallard Island, table 1), only turbidity was measured (model DTS-12, Forest Technology Systems, Blaine, Wash.). All turbidity data were collected according to International Organization for Standardization standard 7027 (International Organization for Standardization, 1999). Optical side-scattering turbidity sensors, which measure the amount of light reflected at a 90-degree angle, were used because they are less sensitive to changes in particle size than optical backscattering sensors (Druine and others, 2018).

\section{Network Maintenance and Sample Collection}

All standard USGS protocols for continuous water-quality monitoring outlined in Wagner and others (2006) were followed during each site visit. To evaluate specific conductance sensor fouling, the modified standard protocol for rapidly changing conditions was followed (Wagner and others, 2006). Routine site visits were conducted to remove biological growth, evaluate sensor calibration, and collect water samples for SSC analysis. Formazin-based calibrants made in the laboratory were used to check turbidity-sensor calibration (Anderson, 2005).

Water samples for SSC analysis were collected at the end of each site visit using a horizontally positioned Van Dorn-style 2.2-liter (L) water sampler (fig. 3C). The sampler is composed of a 12.7-centimeter $(\mathrm{cm})$ diameter acrylic tube with rubber seals at each end that snap shut when triggered by the release of a messenger weight sliding down the deployment cable. A 13.6-kilogram $(\mathrm{kg})$ sounding weight was attached beneath the acrylic tube to maintain the sampler's position at depth in large currents. The sampler was lowered to the depth of the deployed sensor using a sounding reel and triggered with a messenger to collect a water sample concurrent with a turbidity-sensor measurement. The sampler was then returned to the surface and agitated prior to transferring a 1.0-liter aliquot to a high-density polyethylene bottle for transport (Wilde and others, 2014). 


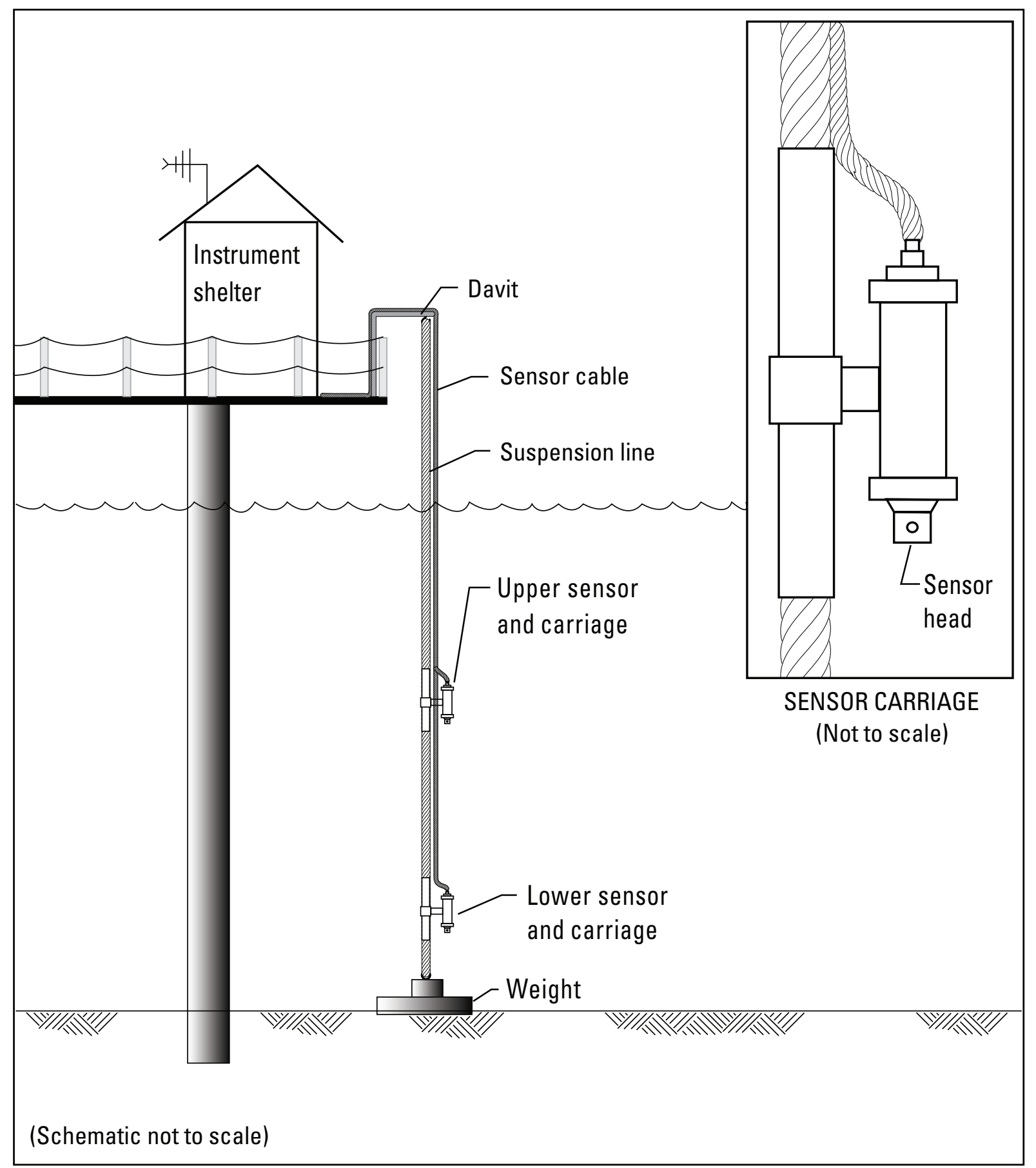

Figure 2. Typical monitoring station, San Francisco Bay area, California.

Water samples were processed at the USGS Santa Cruz Sediment Analysis Laboratory for suspended-sediment concentration (SSC) using methods from Guy (1969). The mass of all particles that did not pass through a 0.45 -micrometer $(\mu \mathrm{m})$ membrane filter was determined after rinsing with de-ionized water to remove salts and oven-drying at $103{ }^{\circ} \mathrm{C}$. The recorded mass was then divided by the original volume of water in the sample to obtain the concentration of suspended sediments in units of milligrams per liter $(\mathrm{mg} / \mathrm{L})$. These discrete water samples were used to relate continuous turbidity measurements to continuous SSC time series (see the "Estimation of suspended-sediment concentration" section later in this report). 
$\boldsymbol{A}$

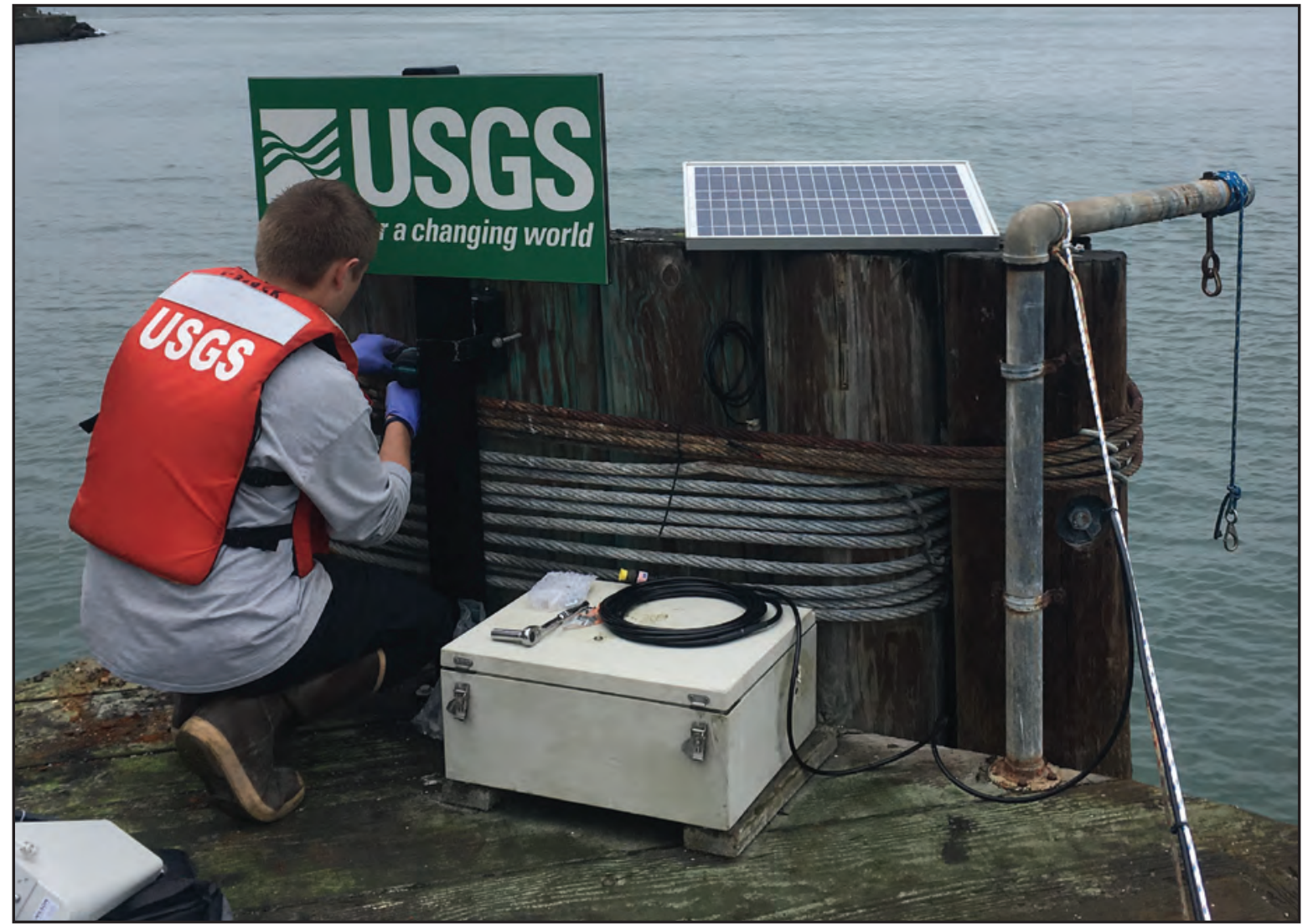

B
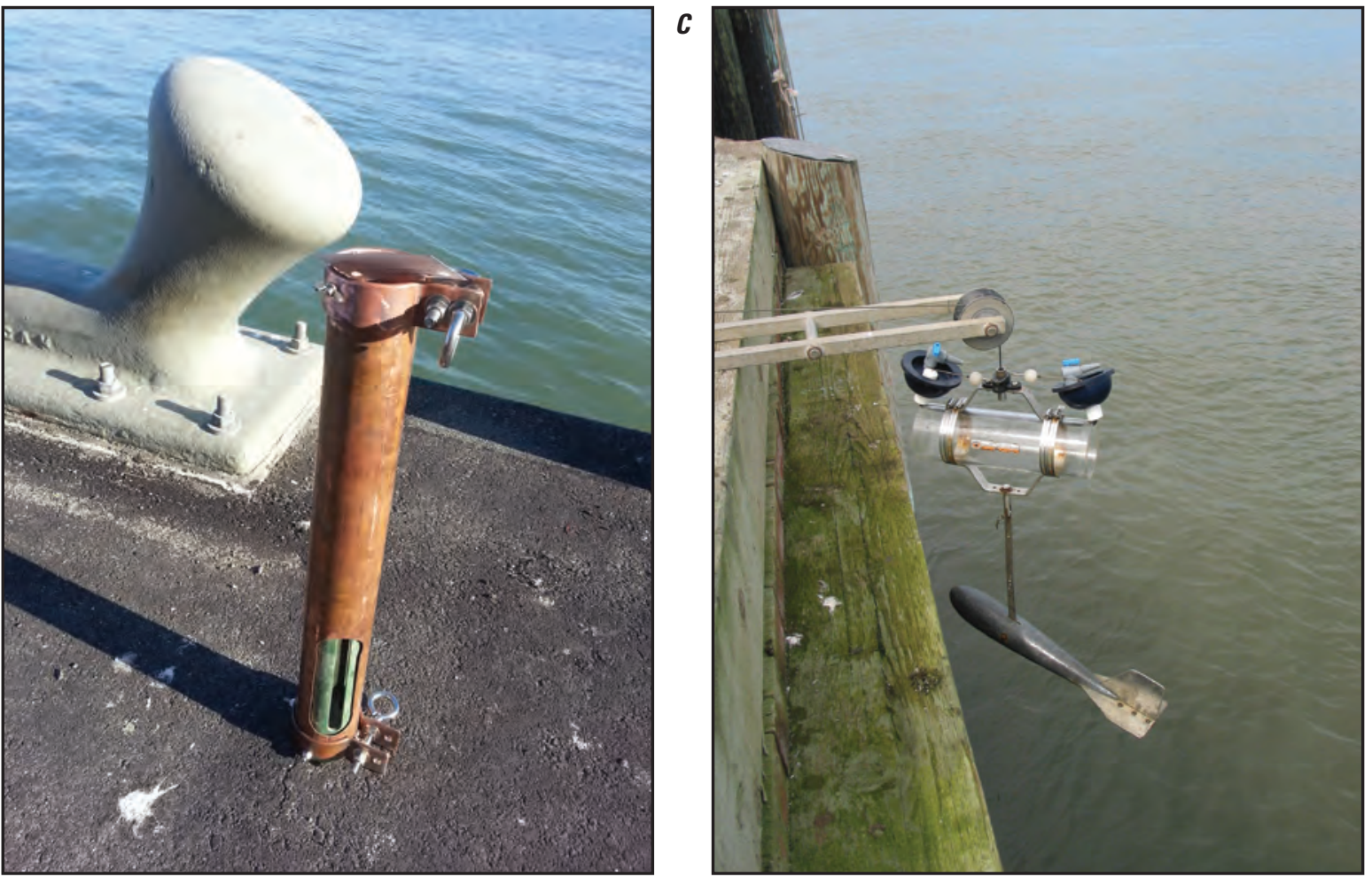

Figure 3. Example of water-quality monitoring equipment $A$, deployed at Alcatraz Island in the central San Francisco Bay (site number 374938122251801); $B$, the copper carriage to protect instrumentation from debris and reduce biological growth (carriage is 67 centimeters in length); and $C$, Van Dorn-style 2.2-liter water sampler used to collect discrete water samples for subsequent suspended-sediment concentration analysis (acrylic tube is 13 centimeters in diameter). 


\section{Water-Quality Data Review and Publication}

Data were evaluated for accuracy of calibration and corruption of signal by sensor malfunction or interference from biological growth (that is, biofouling). Corrections for calibration drift identified during site visits were applied during data review and quality assurance prior to final publication. Data affected by sensor malfunction were deleted; sensor malfunction can be caused by infiltration of water into the sensor housing, communication cable failure, or damage to the deployment infrastructure. Interference from biological growth on the sensors primarily affects specific conductance and turbidity data.

Biological growth rates on sensors can increase in the summer months because of warmer temperatures and increased specific conductance. Specific conductance data affected by biological growth can be corrected in some instances (Wagner and others, 2006). Specific conductance corrections were applied during data review and quality-assurance processes. Specific conductance data affected by biological fouling exhibit a non-linear decrease in reported values due to exponential growth rates of biota within the measurement cell. If the signal retains its amplitude, a correction can be applied. The correction procedure entails a series of piecewise-linear corrections applied from the onset of biological growth to the time at which the range of the tidal signal is visibly attenuated compared to other available sensor data. Data after this time were deleted. This correction procedure deviated from methods in Wagner and others (2006) but was warranted given the non-linear decrease driven by exponential growth of biota on sensor bodies in tidal environments. Application of standard procedures in this environment would result in an erroneous final time series for specific conductance data. Turbidity data affected by biological growth in the study area cannot be corrected and were deleted. Provisional data were approved following analysis and review according to USGS guidelines (Wagner and others, 2006).

\section{Estimation of Suspended-Sediment Concentration}

Continuous estimates of SSC were obtained by developing regression models that relate continuous turbidity measurements to discrete SSC analytical results from water samples. Turbidity is a useful surrogate for SSC because turbidity is primarily controlled by changes in SSC (Downing,
2006). In this study, continuous SSC estimates were computed at each station except at Carquinez Bridge and San Mateo Bridge. For stations with continuous SSC estimates, the appendix provides the regression models used to estimate SSC from turbidity for WY 2017. Here, we provide a brief description of the methods to develop the regression models used to compute continuous SSC estimates from turbidity. The reader is referred to Helsel and Hirsch (2002), Rasmussen and others (2009), and U.S. Geological Survey (2016) for more details.

Three models that relate continuous turbidity and discrete SSC were considered (fig. 4): linear ordinary least squares regression, log-transformed ordinary least squares regression, and non-parametric Kendall-Theil regression (see Helsel and Hirsch, 2002). Model selection was based on standard diagnostics from Helsel and Hirsch (2002): coefficients of determination (adjusted $\mathrm{R}^{2}$ ), model standard percentage error (MSPE), the distribution of regression residuals, and the relationship of regression residuals to SSC and time (fig. 4). Model selection was verified following Rasmussen and others (2009). The non-parametric Kendall-Theil regression was only used if the assumptions of normality were not met for ordinary least squares regression. Outliers were identified using studentized residuals, leverage, Cook's distance, and DFFITS (Helsel and Hirsch, 2002). Briefly, studentized residuals and leverage are measures of outliers in the " $y$ " and " $\mathrm{x}$ " directions, respectively. Cook's distance and DFFITS estimate the amount of influence a data point has on regression coefficients; including data that have a large influence on regression coefficients can result in regression coefficients indicating low statistical significance and in unreliable estimates of SSC. Data points not meeting regression diagnostic criteria were flagged and investigated as potential outliers. Flagged observations are only excluded from the regression analysis if sampling or laboratory error is suspected.

The final regression model (presented by station in appendix 1) was used to compute continuous SSC estimates from turbidity. For example, for the upper sensor at Benicia Bridge (fig. 4; table 1) the linear regression model $\mathrm{SSC}=1.56 \times$ turbidity +1.69 was used to estimate SSC from turbidity because this regression minimized MSPE, model residuals did not covary with SSC or time, and regression residuals exhibited a normal distribution (figs. $4 A-C$ ). The data, statistics, and regression models used to compute $\mathrm{SSC}$ at each sensor in the network are provided in appendix 1 following the format specified by the U.S. Geological Survey (2016). 
A

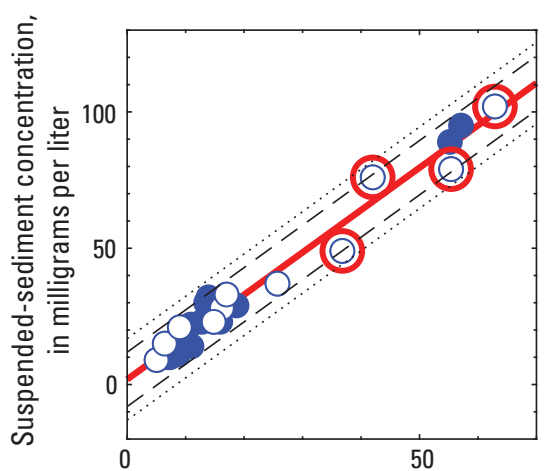

Turbidity, in formazin nephelometric units

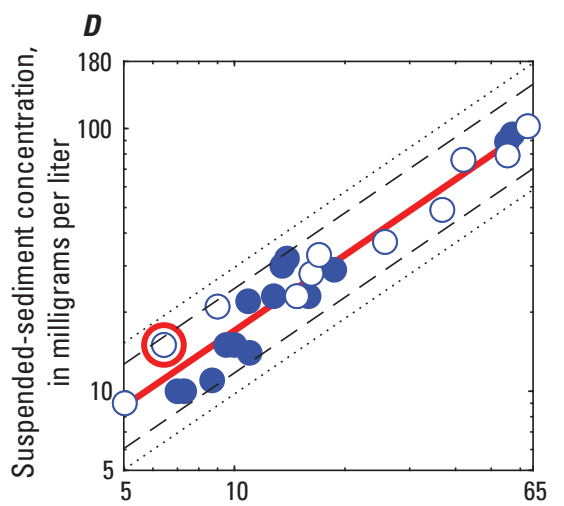

Turbidity, in formazin nephelometric units

G

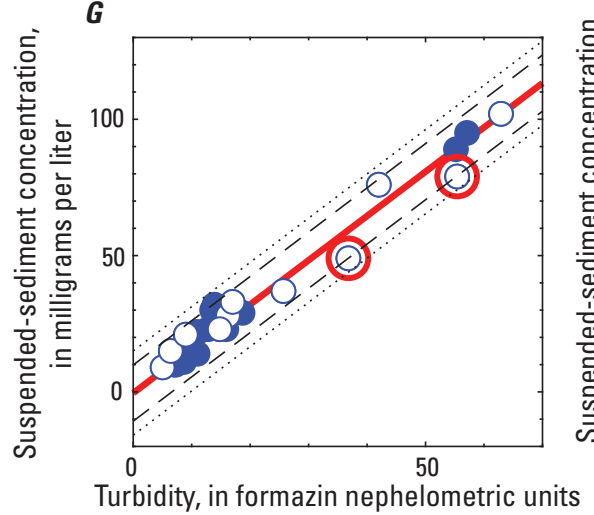

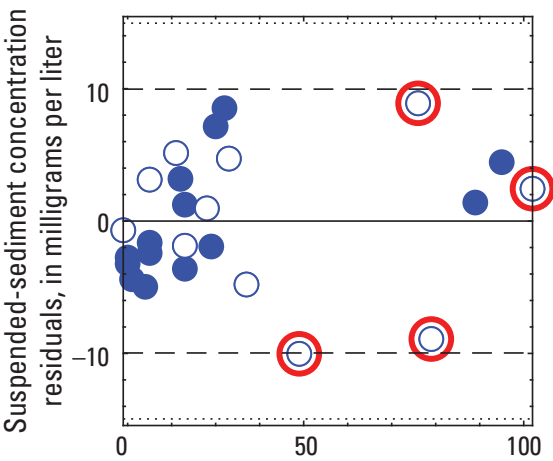

Suspended-sediment concentration, in milligrams per liter

$E$

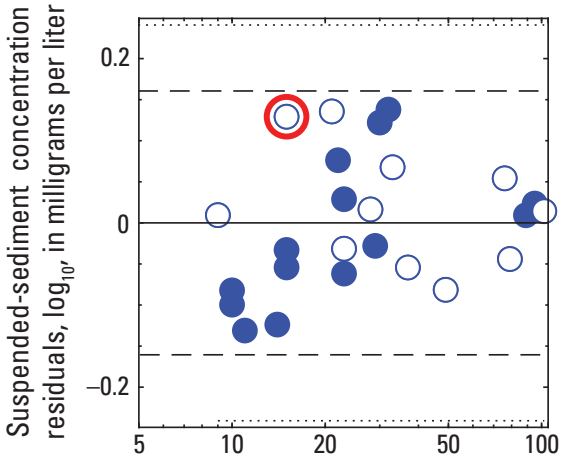

Suspended-sediment concentration, in milligrams per liter

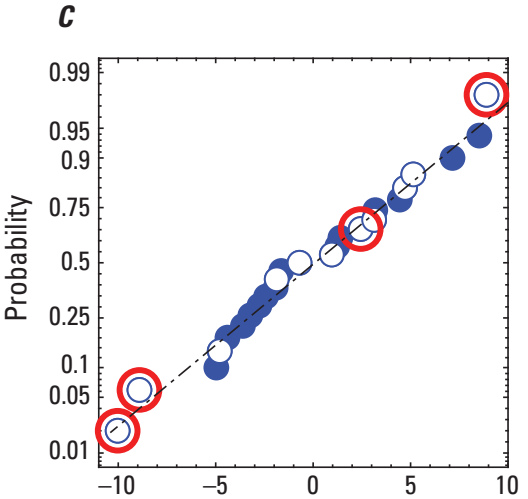

Suspended-sediment concentration residuals, in milligrams per liter

$\boldsymbol{F}$

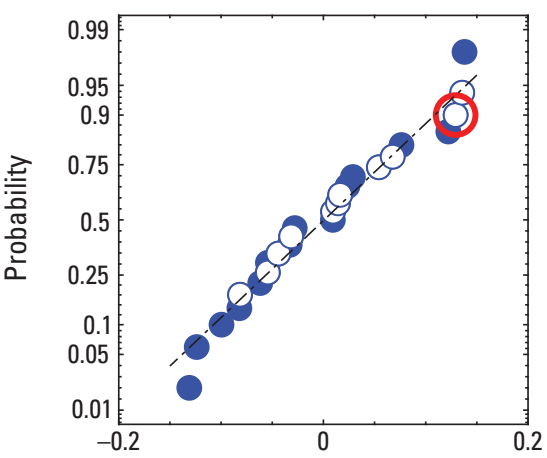

Suspended-sediment concentration residuals, $\log _{10}$ in milligrams per liter

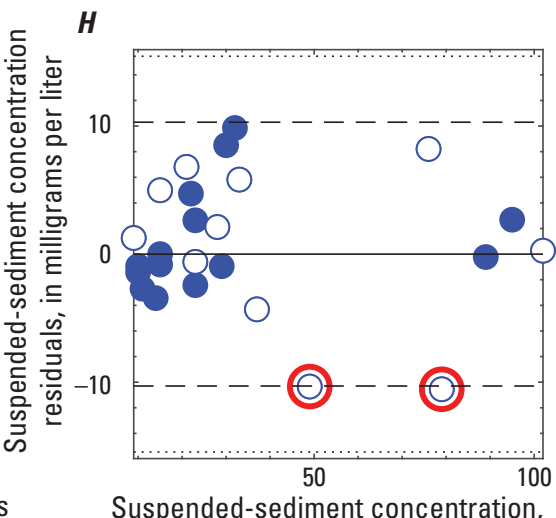
in milligrams per liter

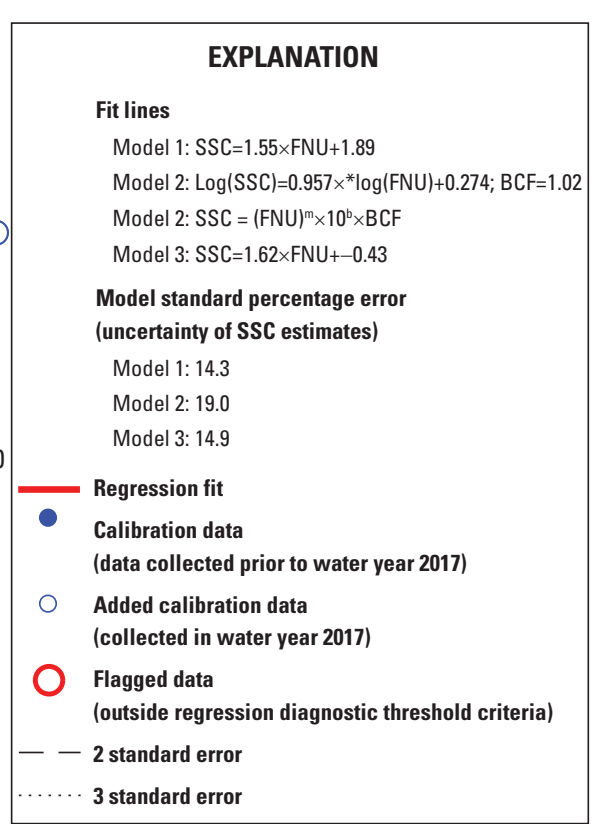

Figure 4. Statistical assessment of different regression models relating turbidity to suspended-sediment concentration (SSC) at the upper sensor position of Benicia Bridge in Suisun Bay, Calif. (site number 11455780), for water year 2017: $A$, linear regression; $B$, linear regression residuals as a function of SSC; $C$, normal probability plots of linear regression residuals for ordinary least-squares regressions; $D$, log-transformed regression; $E$, log-transformed regression residuals as a function of SSC; $F$, normal probability plots of log-transformed regression residuals for ordinary least-squares; $G$, Kendal-Thiell regression; and $H$, Kendal-Thiell regression residuals as a function of SSC. 


\section{Results and Discussion}

The monitoring network was designed to capture short-term (tidal to seasonal) and long-term (interannual) variability in SFB water quality. Short-term monitoring provides information about short-term events such as storms and dredging operations that affect estuarine water quality, whereas long-term water-quality monitoring provides information necessary to assess trends. In this report, visual summaries are presented to characterize interannual variations in specific conductance, temperature, turbidity, and SSC in the SFB. Prior to WY 2013, turbidity data were analyzed and used to develop regression models and compute continuous estimates of SSC, but these data were not published; thus, in this report, turbidity data are presented for WY 2013-17.

To summarize the data, box-and-whisker plots are presented for each parameter at all stations, listed from north to south, and computed on an annual water year basis (figs. 5-12). Box-and-whisker plots are used to display interannual changes in the annual minimum, maximum, and the $0.25,0.5$ (median), and 0.75 quantiles. Annual graphical summaries are excluded for the years in which parameters had a data gap exceeding 45 consecutive days. The horizontal and vertical scales in figures 5-12 are the same to aid comparison of parameters among stations. If an annual maximum exceeds the plot range, the maximum value is displayed on the figure as text (see fig. $5 A$ ).

During the periods of record, water-quality data exhibited vertical and horizontal spatial variability typical of estuarine systems. Vertically, as observed at stations with two sensors in the water column, summary statistics demonstrated that specific conductance and turbidity were generally higher near the bed (figs. $6 \mathrm{~A}, 6 \mathrm{C}$ ), owing to gravity-induced downward movement of denser saline water and settling of suspended sediment. Similar vertically uniform distributions of water-quality parameters (for example, specific conductance for upper and lower sensors at San Mateo Bridge, fig. 11A) indicte a typically well-mixed location in the estuary. In contrast, distributions of parameters that differed between the upper and lower sensors (for example, specific conductance for upper and lower sensors at Benicia Bridge, fig. 6A) indicated an area of less vertical mixing because of freshwater input and the resulting estuarine stratification. Benicia Bridge in Suisun Bay is near the primary source of freshwater inflow to the SFB (the Sacramento-San Joaquin Delta) and, generally, specific conductance near the water surface was lower because of fresher, less dense water in the upper water column (fig. 6A). Stations farther seaward exhibited less vertical variability in specific conductance, as evidenced by more similar distributions for upper and lower sensors (for example, compare Benicia to the Richmond-San Rafael Bridge, figs. $6 A$ and $8 A$ ).

In the horizontal direction, variability in specific conductance and water temperature increased with proximity to freshwater inflow from the Sacramento-San Joaquin Delta, owing to seasonal and interannual variations in hydrologic conditions. For example, Benicia Bridge, one of the stations nearest the freshwater inflow, exhibited greater variations annually (that is, greater interquartile range, or IQR) and interannually (that is, more variability in the IQR) for specific conductance and water temperature (figs. $6 A-B$ ) compared to stations farther away (figs. $9 A-B$ and $11 A-B$ ). As distance from freshwater inflow increases, ocean influence increases, leading to reduced annual and interannual variability. Similar observations have been made by other researchers (for example, Shellenbarger and Schoellhamer, 2011; Downing-Kunz and others, 2015).

Interannual water quality changed notably during the recent WY 2012-16 drought, which has been identified as the most severe drought conditions in central and southern California during the last 1,200 years (Griffin and Anchukaitis, 2014). In the estuary, record-high specific conductance and water temperature were recorded in WY 2014 and WY 2015 (see parts $A$ and $B$ in figs. 6-12; also see Downing-Kunz and others, 2015; Work and others, 2017). The cause of the recent increase in water temperatures through the WY 2012-16 drought noted by Downing-Kunz and others (2015) and Work and others (2017) is being investigated. Possible causes include increased water temperatures from the ocean or watersheds (Work and others, 2017), changes in freshwater inflow magnitude or timing (Downing-Kunz and others, 2015), increased air temperatures over the estuary, and decreased cooling of estuary water from decreased wind velocity (Bever and others, 2018).

Median annual turbidity and SSC were lowest in the central SFB (Alcatraz Island, figs. $9 C-D$, and Pier 17, figs. $10 C-D$ ), whereas median annual turbidity and SSC were typically highest in the south SFB at Dumbarton Bridge (figs. $12 C-D$ ). The long-term variability in turbidity was not assessed, given the relatively short period of record; however, given its relation to SSC, we can infer changes in turbidity by evaluating changes in SSC. The largest system-wide change in SSC during the period of record was noted by Schoellhamer (2011) as an estuary-wide step decrease in SSC in 1999. This decline in SSC is thought to be driven by passage of the sediment pulse initiated by large-scale mining during California's Gold Rush begun in the mid-1850s (Schoellhamer, 2011). Concurrent with increases in specific conductance and temperature during the recent drought, SSC at some stations increased during WY 2012-16 to values reaching pre-1999 levels; for example, at Mallard Island (fig. 5B) and at Dumbarton Bridge (fig. 12D). For south SFB (as observed at Dumbarton Bridge), an explanation for this increase in SSC could be decreased estuarine circulation (Geyer and MacCready, 2014) caused by reduced freshwater inflow to the estuary; water in south SFB typically has higher SSC than water in the Pacific Ocean (Conomos and Peterson, 1977), and estuarine circulation affects the amount of mixing between these regions. Thus, reduced mixing between high-SSC south SFB water and low-SSC Pacific Ocean water could lead to observations of higher SSC in south SFB. 

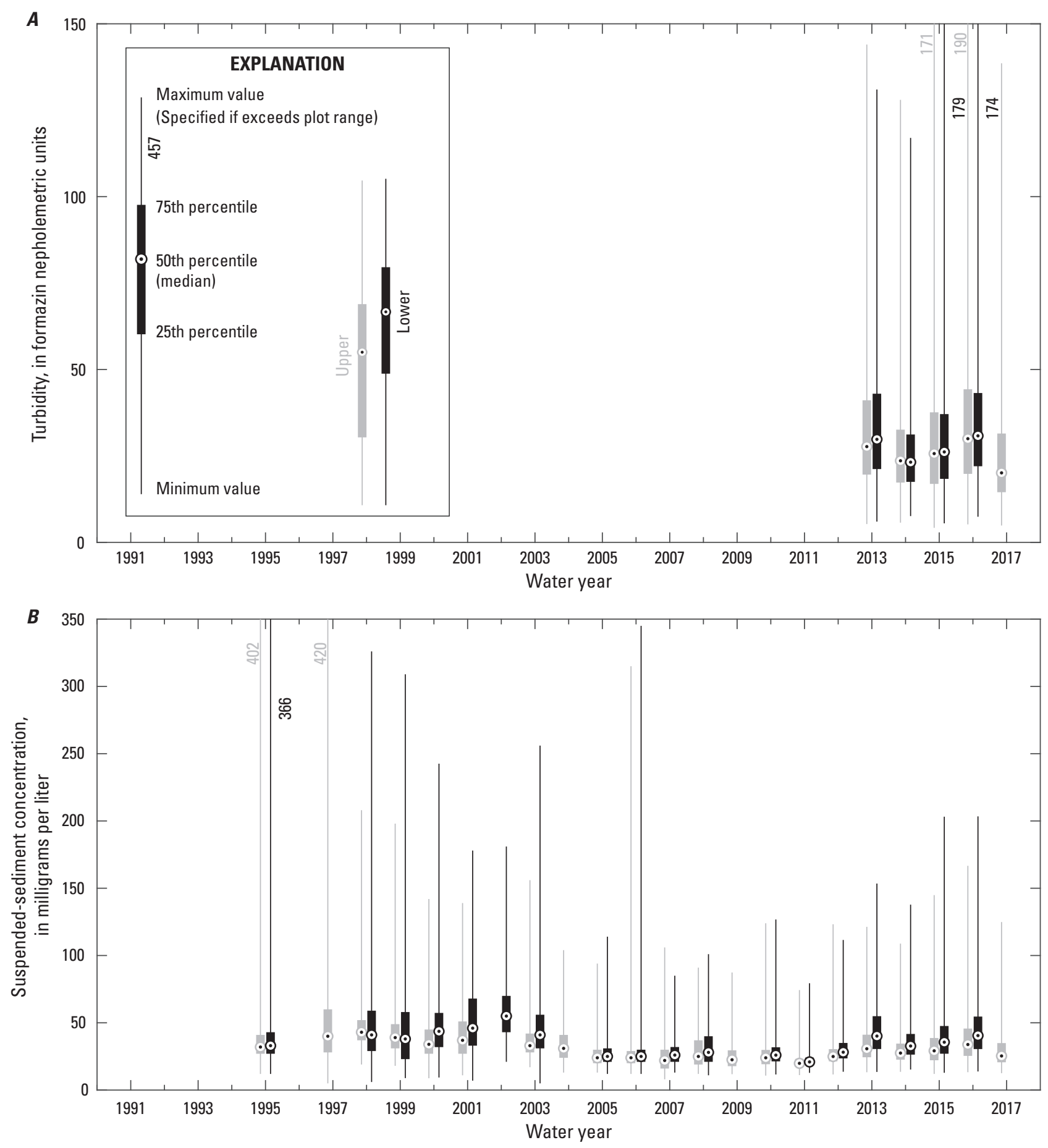

Figure 5. Distribution and variability of water-quality data at Mallard Island in Suisun Bay, Calif. (site number 11185185), by water year from 1995 to 2015 (are omitted for water years having a data gap longer than 45 days in length): $A$, turbidity, and $B$, suspended-sediment concentration (SSC). Two sondes, termed "upper" and "lower" are deployed at this site. The upper sonde is deployed on a float $1 \mathrm{~m}$ below the water surface and the lower sonde is deployed $6.5 \mathrm{~m}$ from mean lower low water. Mean lower low water at this site is $7.6 \mathrm{~m}$ above the bed. 


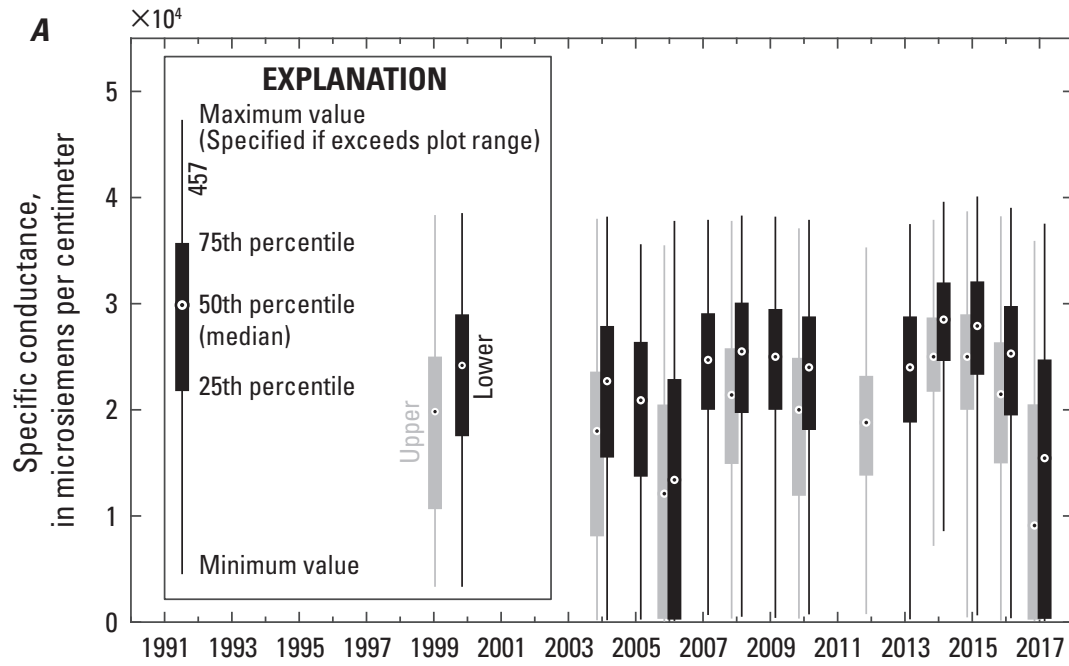
Water year

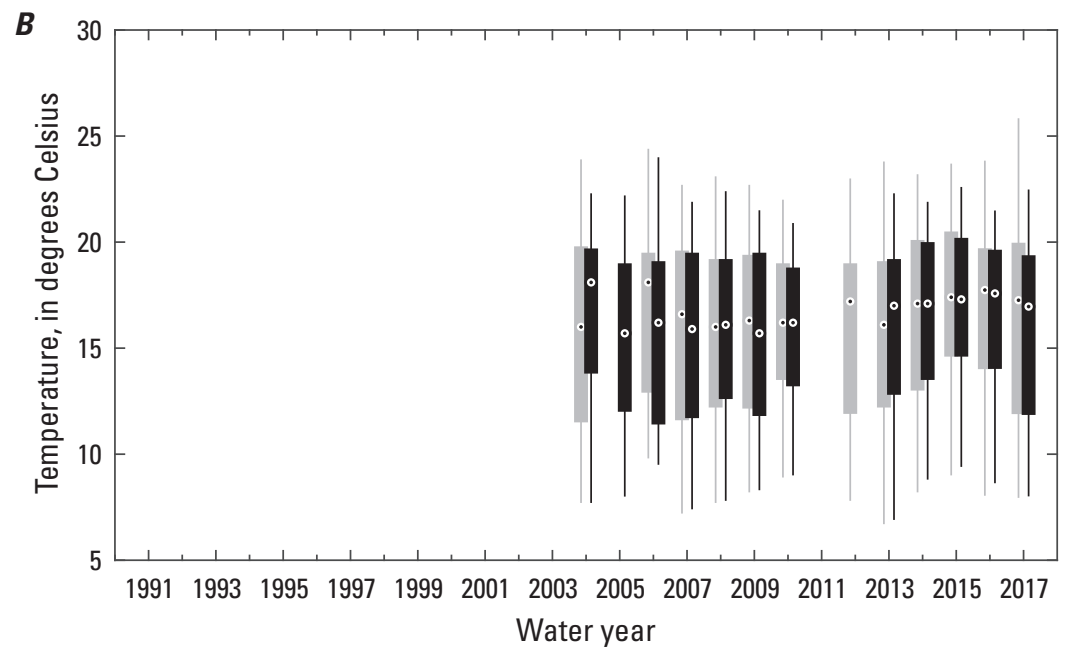

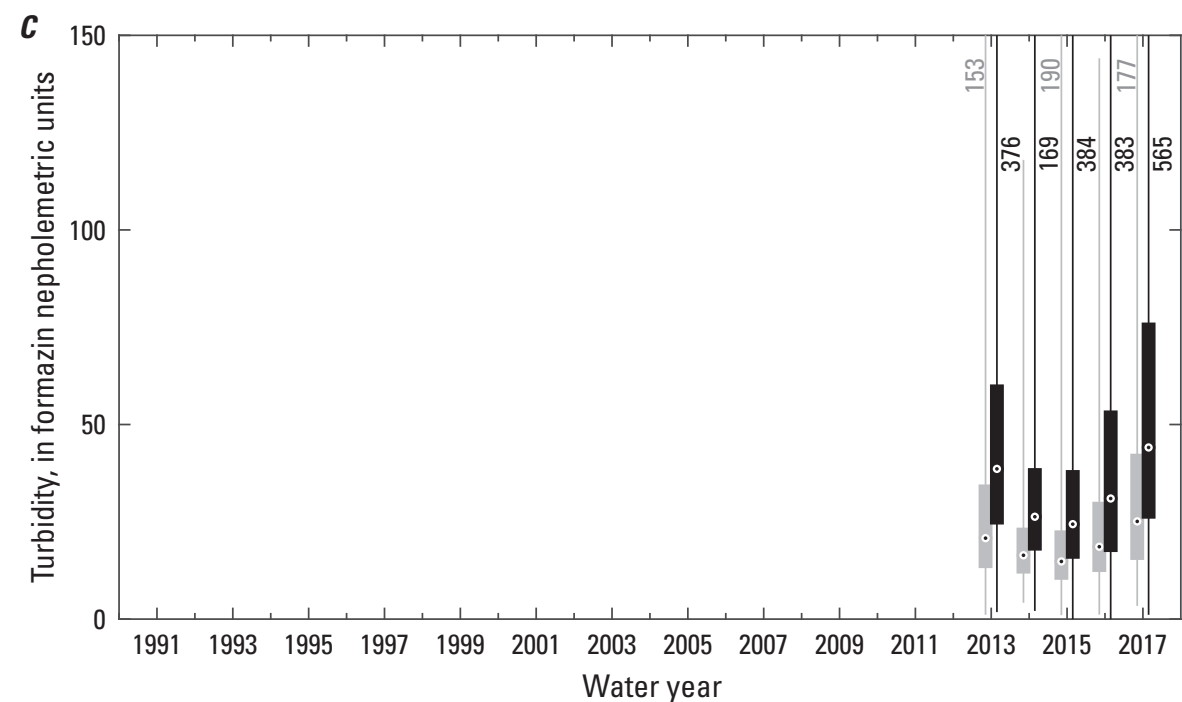

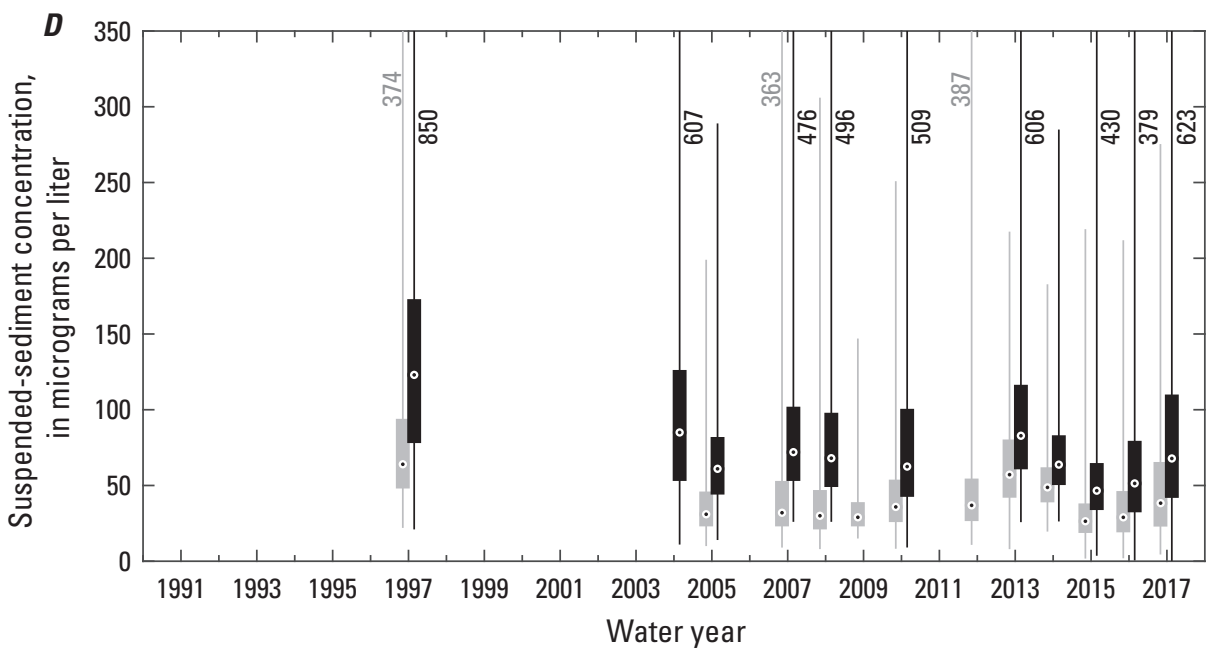

Figure 6. Distribution and variability of water-quality parameters at Benicia Bridge in Suisun Bay, Calif. (site number 11455780 ), by water year from 1997 to 2015 (data are omitted for water years having a data gap longer than 45 days in length): $A$, specific conductance; $B$, temperature; $C$, turbidity; and $D$, suspended-sediment concentration (SSC). Two sondes, termed "upper" and "lower" are deployed at this site. The upper sonde is deployed $2.4 \mathrm{~m}$ from mean lower low water and the lower sensor is deployed $18.6 \mathrm{~m}$ from mean lower low water. Mean lower low water at this site is $24.4 \mathrm{~m}$ above the bed. 
$\boldsymbol{A}$
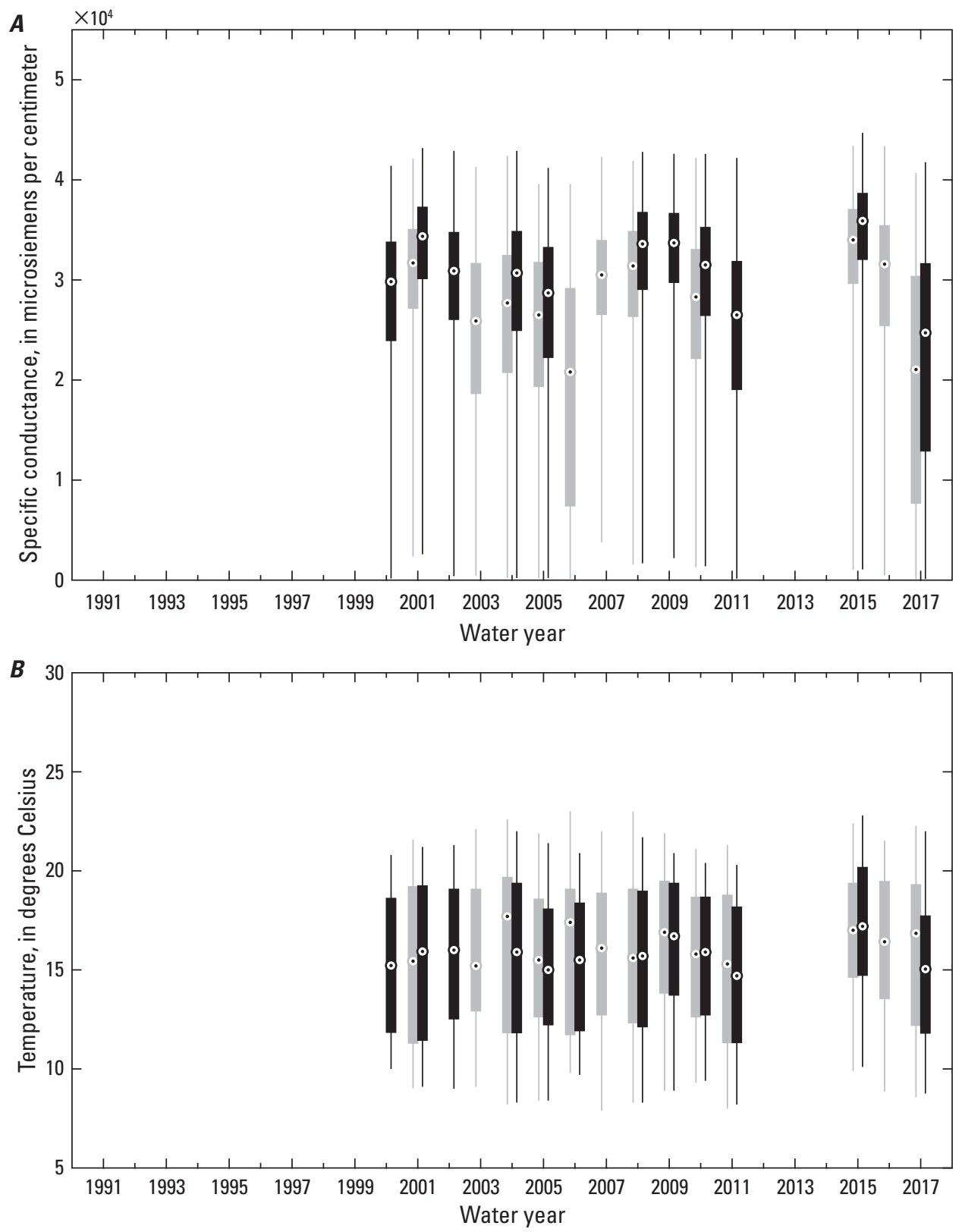

Figure 7. Distribution and variability of water-quality parameters at Carquinez Bridge in Carquinez Strait, Calif. (site number 11455820), by water year from 2000 to 2017 (data are omitted for water years having a data gap longer than 45 days in length): $A$, specific conductance, and $B$, temperature. Two sondes, termed "upper" and "lower" are deployed at this site. The upper sondes is deployed $9.2 \mathrm{~m}$ from mean lower low water and the lower sonde is deployed $22.3 \mathrm{~m}$ from mean lower low water. Mean lower low water at this site is $23.8 \mathrm{~m}$ above the bed. 

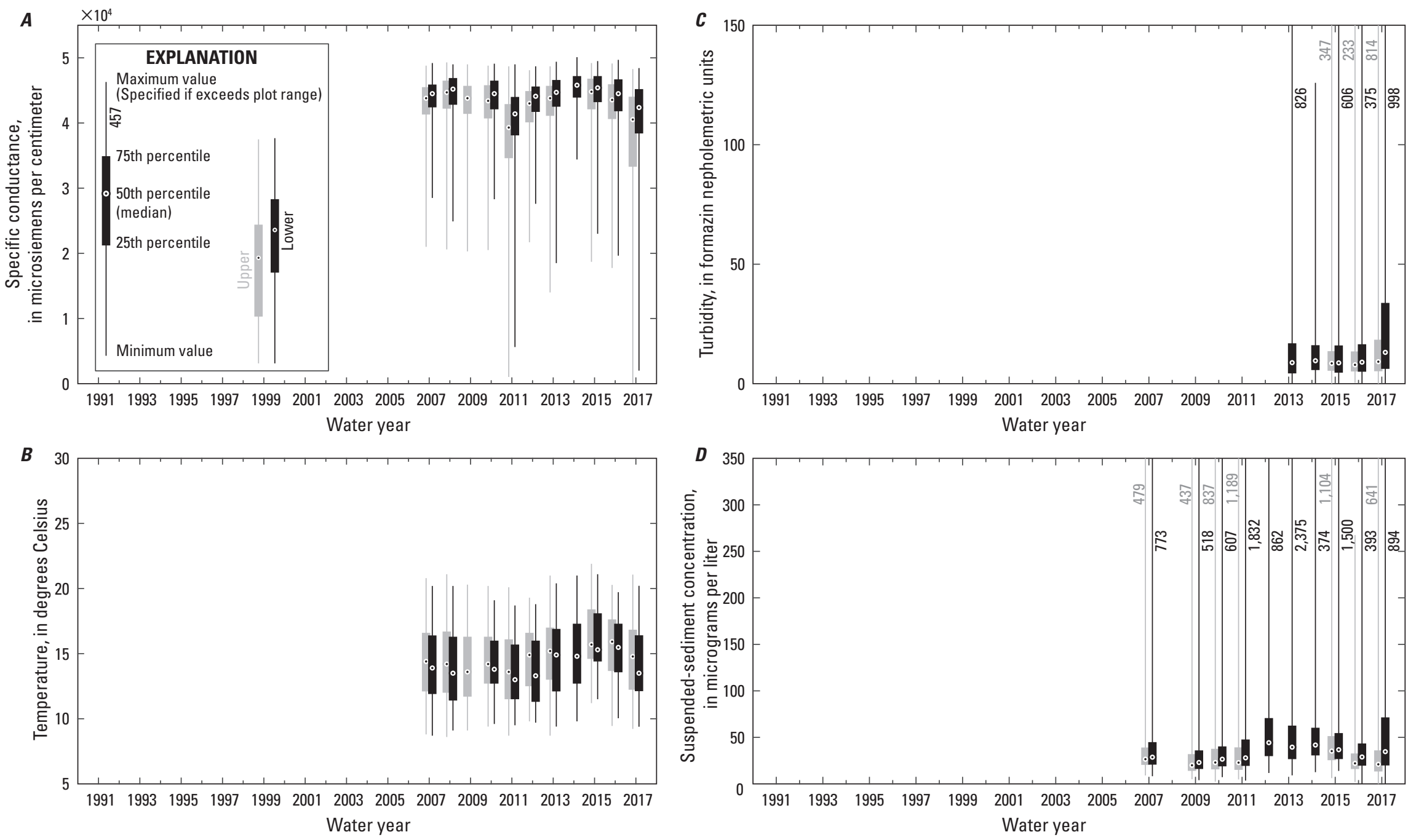

Figure 8. Distribution and variability of water-quality parameters at Richmond-San Rafael Bridge in San Pablo Bay, Calif., (site number 375607122264701), by water year from 2007 to 2017 (data are omitted for water years having a data gap longer than 45 days in length): $A$, specific conductance; $B$, temperature; $C$, turbidity; and $D$, suspended-sediment concentration (SSC). Two sondes, termed "upper" and "lower" are deployed at this site. The upper sonde is deployed $4.6 \mathrm{~m}$ from mean lower low water and the lower sonde is deployed $12.2 \mathrm{~m}$ from mean lower low water. Mean lower low water at this site is $13.7 \mathrm{~m}$ above the bed. 


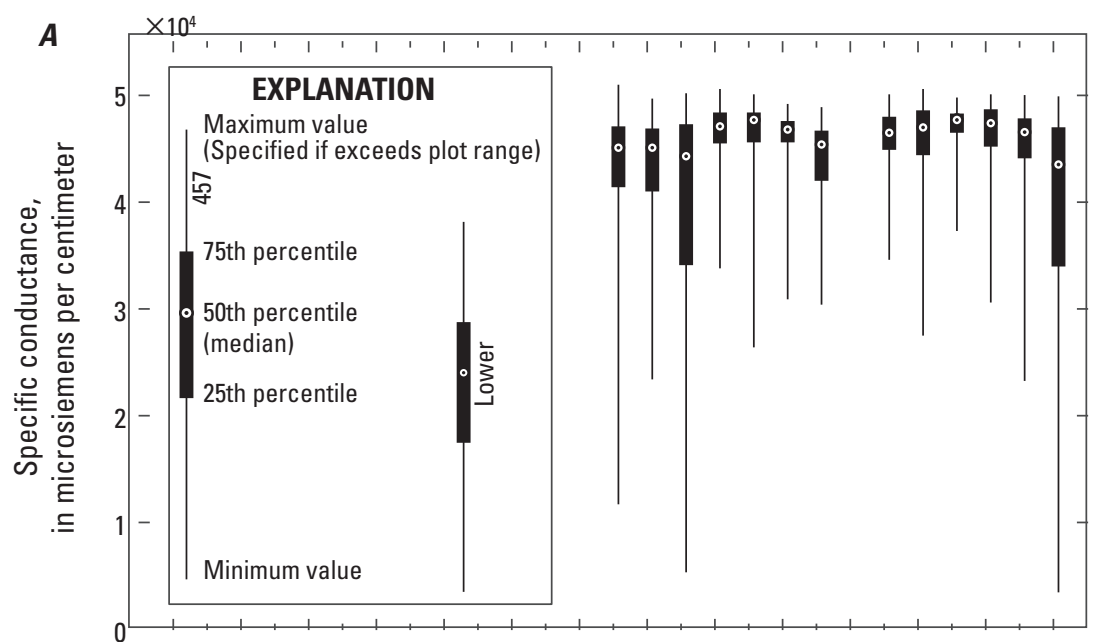

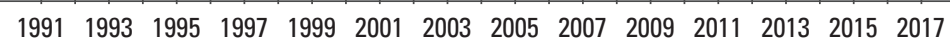

Water year

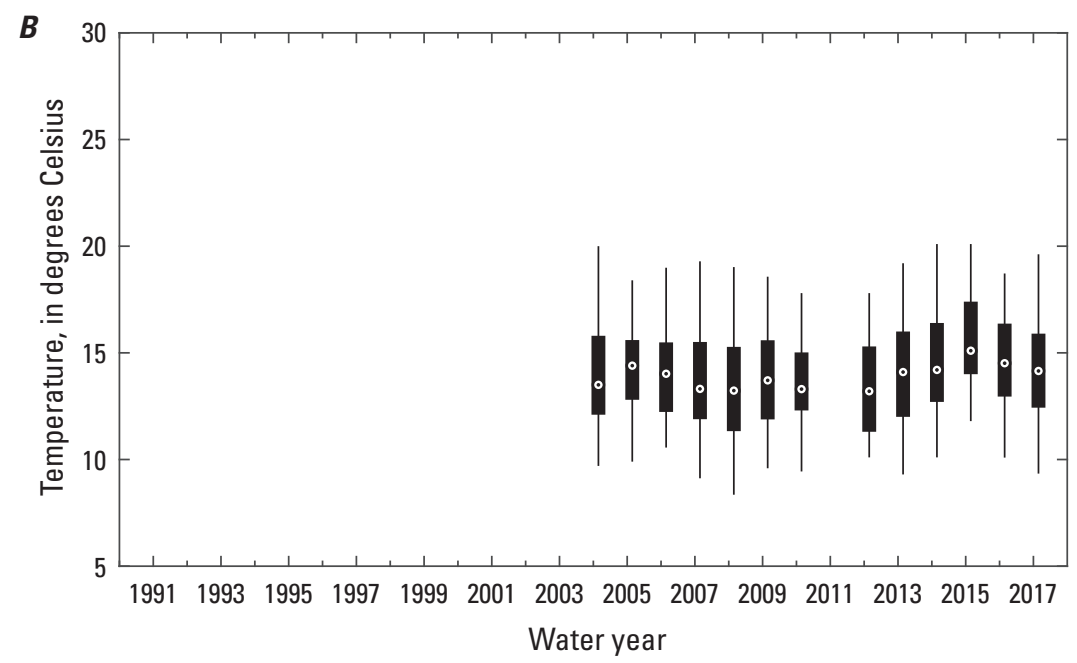

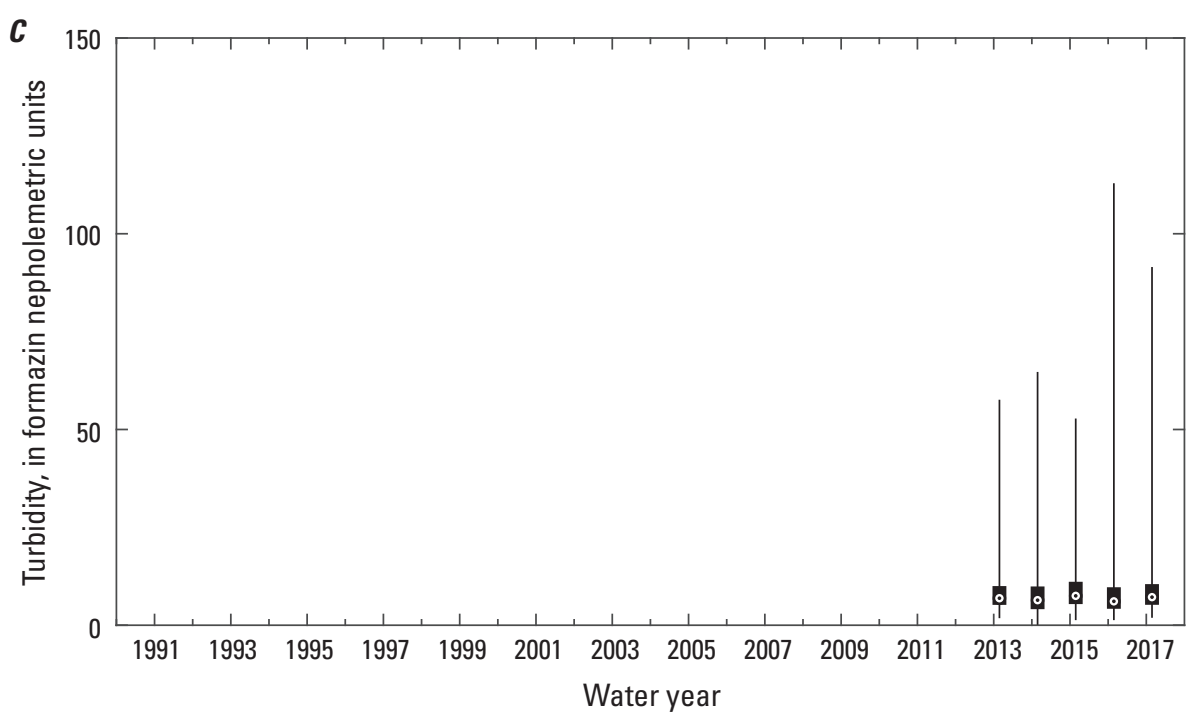

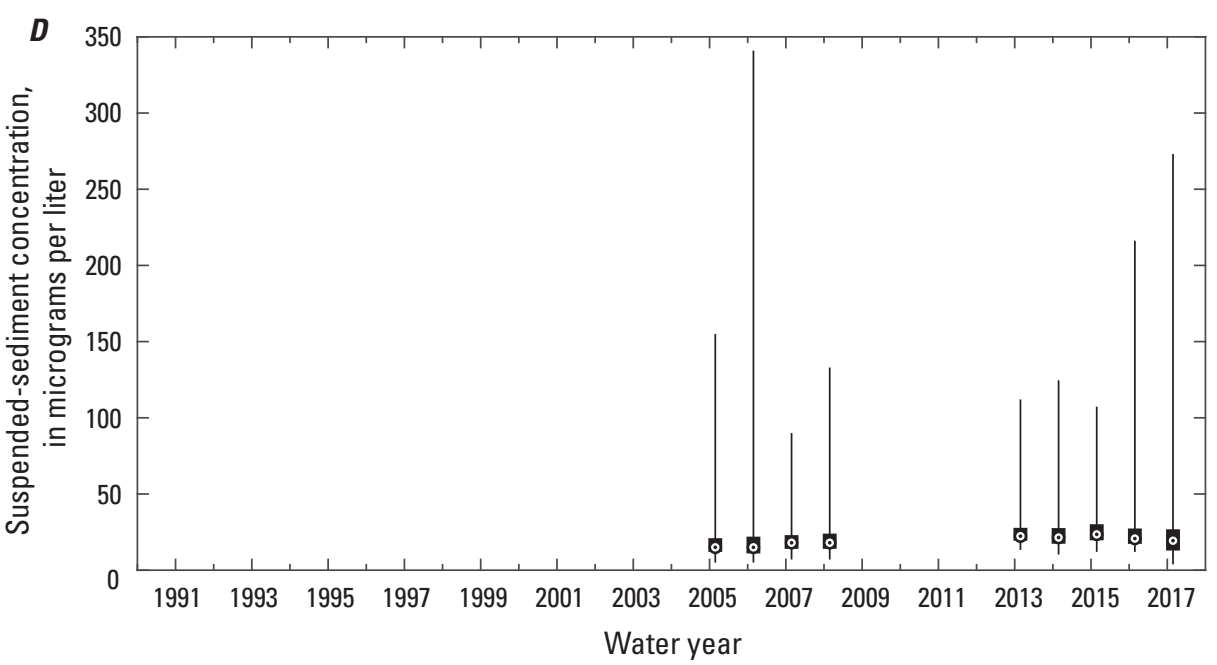

Figure 9. Distribution and variability of water-quality parameters at Alcatraz Island in Central San Francisco Bay, Calif. (site number 374938122251801 ), by water year from 2004 to 2017 (data are omitted for water years having a data gap longer than 45 days in length): $A$, specific conductance; $B$, temperature; $C$, turbidity; and $D$, suspended-sediment concentration (SSC). The sonde is deployed at $1.6 \mathrm{~m}$ from mean lower low water. Mean lower low water at this site is $4.9 \mathrm{~m}$ above the bed. 

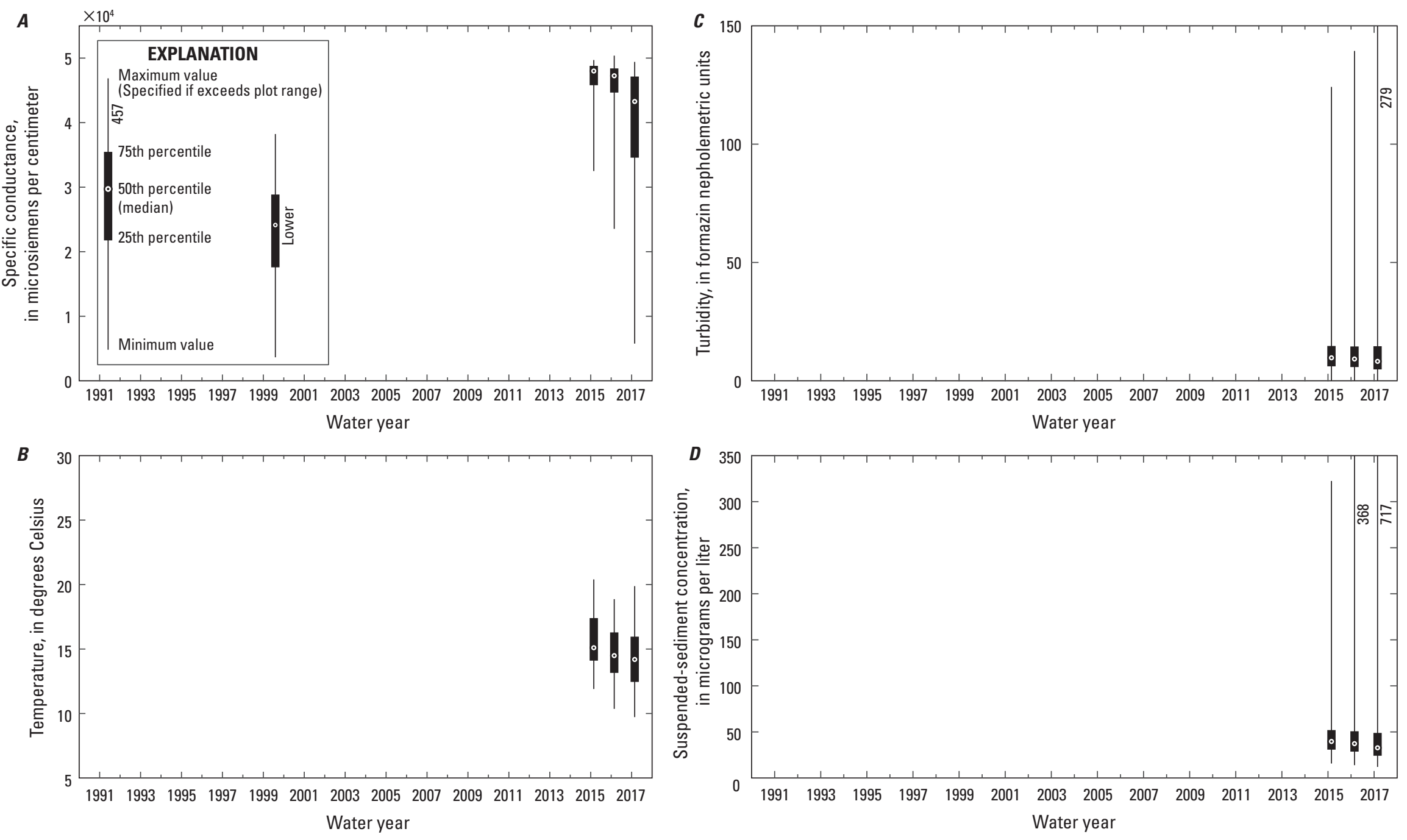

Figure 10. Distribution and variability of water-quality parameters at Pier 17 in Central San Francisco Bay, Calif. (site number 374811122235001 ), by water year from 2015 to 2017 (data are omitted for water years having a data gap longer than 45 days in length): $A$, specific conductance; $B$, temperature; $C$, turbidity; and $D$, suspended-sediment concentration (SSC). The sonde is deployed at $3.7 \mathrm{~m}$ from mean lower low water. Mean lower low water at this site is $4.9 \mathrm{~m}$ above the bed. 


\section{A}
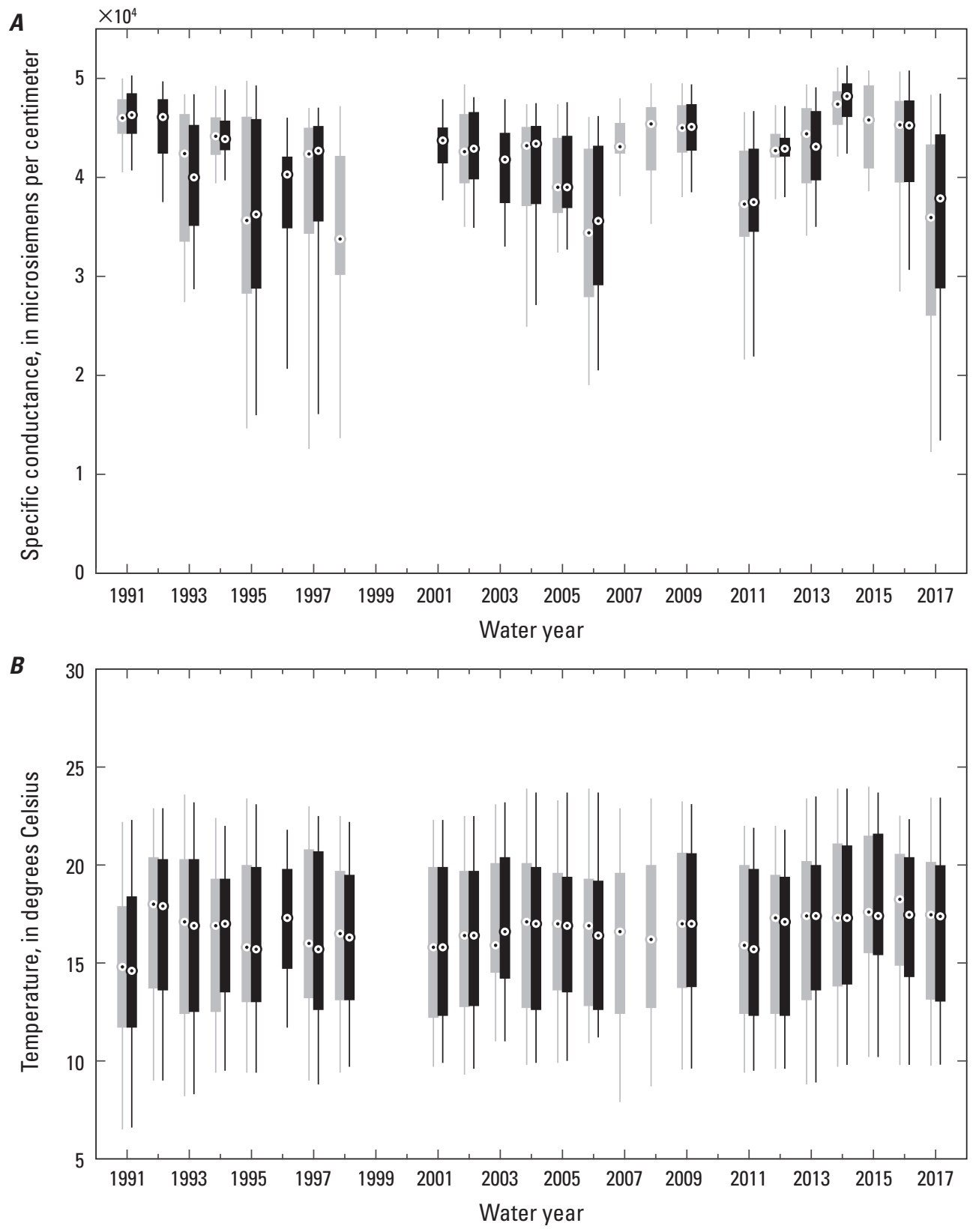

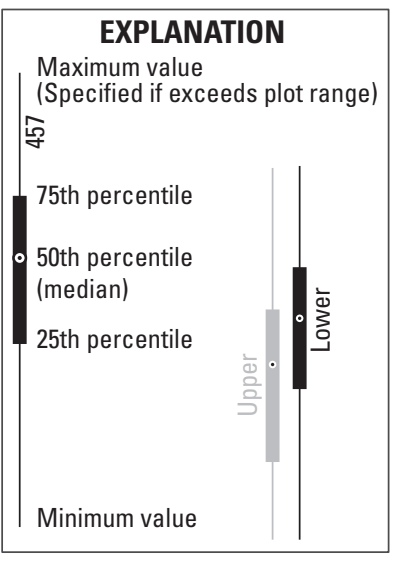

Figure 11. Distribution and variability of water-quality parameters at San Mateo Bridge in South San Franciscso Bay, Calif. (site number 11162765), by water year from 1991 to 2017 (; data are omitted for water years having a data gap longer than 45 days in length): $A$, specific conductance, and $B$, temperature. Two sondes, termed "upper" and "lower" are deployed at this site. The upper sonde is deployed $1.2 \mathrm{~m}$ from mean lower low water and the lower sonde is deployed $11.6 \mathrm{~m}$ from mean lower low water. Mean lower low water at this site is $14.6 \mathrm{~m}$ above the bed. 

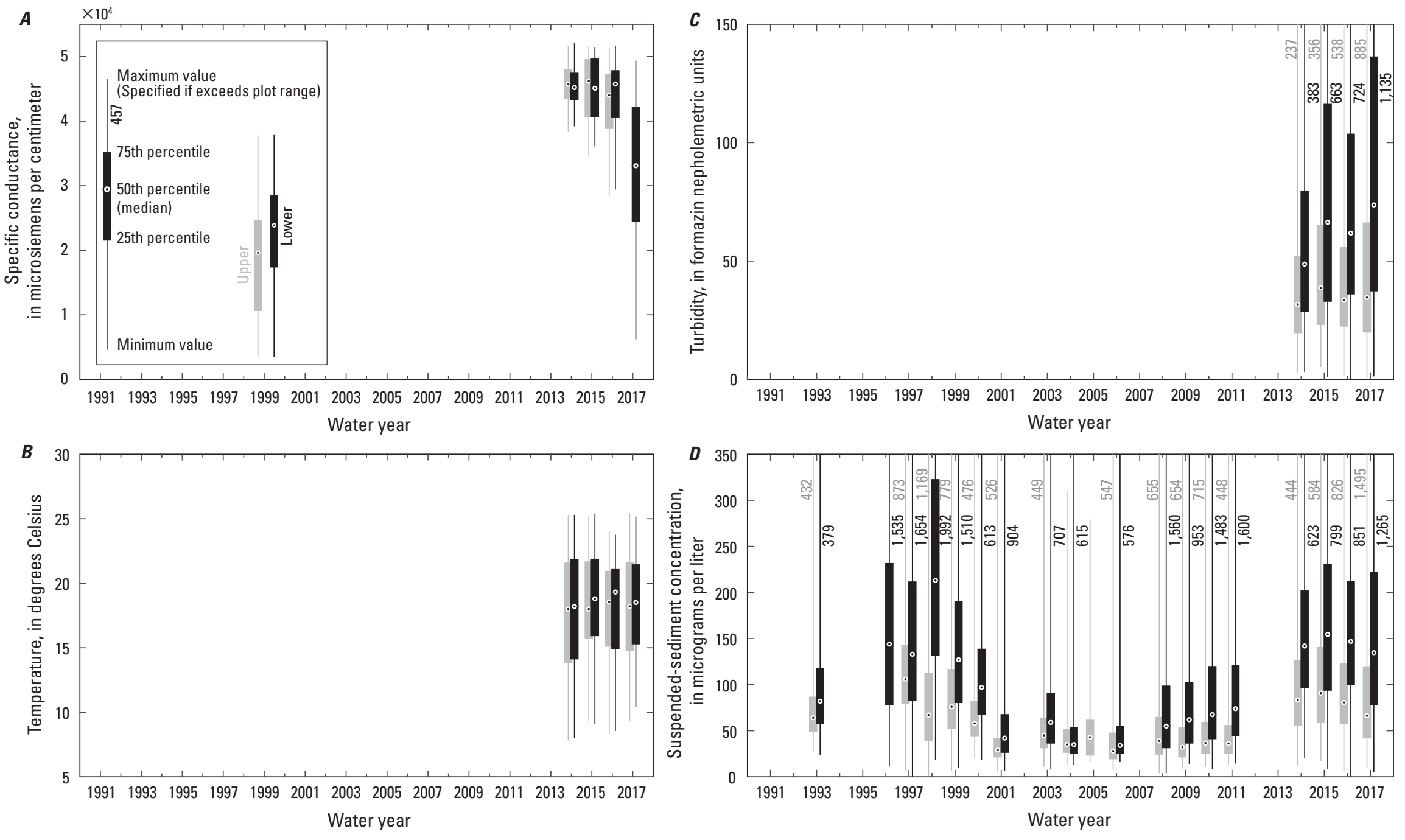

Figure 12. Distribution and variability of water-quality parameters at Dumbarton Bridge in South San Francisco Bay, Calif. (site number 373015122071000), by water year from 1993 to 2017 (data are omitted for water years having a data gap longer than 45 days in length): $A$, specific conductance; $B$, temperature; $C$, turbidity; and $D$, suspended-sediment concentration (SSC). Two sondes, termed "upper" and "lower" are deployed at this site. The upper sonde is deployed $6.1 \mathrm{~m}$ from mean lower low water and the lower sonde is deployed $12.5 \mathrm{~m}$ from mean lower low water. Mean lower low water at this site is $13.7 \mathrm{~m}$ above the bed. 


\section{Summary}

The San Francisco Bay Water-Quality Monitoring and Sediment Transport Project has continuously collected water-quality data since 1989 in San Francisco Bay, the largest and most urbanized estuary on the West Coast of the United States. The goals of the data collection effort are to (1) obtain long-term, high-frequency, and high-quality data to describe San Francisco Bay water quality; (2) make the data publicly available on the USGS National Water Information System data portal; and (3) help improve understanding of the spatial and temporal variability of water quality in the estuary. This report presents methods used, stations operated, and regression models used to relate turbidity to suspended sediment concentration during water year 2017 and summarizes interannual variations in San Francisco Bay water quality. These data have been evaluated to indicate estuary-wide changes in water quality, inform management decisions, and improve our understanding of processes affecting sediment transport. Because of ongoing urbanization and changes in climate and sea level, continued monitoring to track and understand San Francisco Bay water quality can support important resource decisions.

\section{References Cited}

Anderson, C.W., 2005, Turbidity, chap. 6.7 in Wilde, F.D., ed., variously dated, Field measurements: U.S.

Geological Survey Techniques of Water-Resources Investigation Report, book 9, chap. A6, 55 p., https://doi.org/10.3133/twri09A6.7.

Barnard, P.L., Schoellhamer, D.H., Jaffe, B.E., and McKee, L.J., 2013, Sediment transport in the San Francisco Bay coastal system-An overview: Marine Geology, v. 345, p. 3-17, https://doi.org/10.1016/j.margeo.2013.04.005.

Bever, A.J., MacWilliams, M.L., Fullerton, D.K., 2018, Influence of an observed decadal decline in wind speed on turbidity in the San Francisco Estuary: Estuaries and Coasts, v. 41, p. 1943-1967, https://doi.org/10.1007/s12237-018-0403-x.

Borkow, G., and Gabbay, J., 2009, Copper, an ancient remedy returning to fight microbial, fungal and viral infections: Current Chemical Biology, v. 3, no. 3, p. 272-278, https://doi.org/10.2174/187231309789054887.

Brand, A., Lacy, J.R., Hsu, K., Hoover, D., Gladding, S., and Stacey, M.T., 2010, Wind-enhanced resuspension in the shallow waters of South San Francisco Bay-Mechanisms and potential implications for cohesive sediment transport: Journal of Geophysical Research, v. 115, no. C11, 15 p., https://doi.org/10.1029/2010JC006172.
Buchanan, P.A., and Ganju, N.K., 2004, Summary of suspended-sediment concentration data, San Francisco Bay, California, water year 2002: U.S. Geological Survey Open-File Report 2004-1219, 54 p., https://doi.org/10.3133/ofr20041219.

Buchanan, P.A., Downing-Kunz, M., Schoellhamer, D.H., Shellenbarger, G., and Weidich, K., 2014, Continuous water-quality and suspended-sediment transport monitoring in the San Francisco Bay, California, water years 2011-13: U.S. Geological Survey Fact Sheet 2014-3090, 4 p., https://doi.org/10.3133/fs20143090.

Buchanan, P.A., Downing-Kunz, M., Schoellhamer, D.H., and Livsey, D.N., 2018, Continuous water-quality and suspended-sediment transport monitoring in the San Francisco Bay, California, water years 2014-15: U.S. Geological Survey Fact Sheet 2018-3013, 5 p., https://doi.org/10.3133/fs20183013.

Cheng, R.T., and Gartner, J.W., 1984, Tides, tidal and residual currents in San Francisco Bay, California-Results of measurements, 1979-1980: U.S. Geological Survey Water-Resources Investigations Report 84-4339, 319 p., https://doi.org/10.3133/wri844339.

Cloern, J.E., and Jassby, A.D., 2012, Drivers of change in estuarine-coastal ecosystems-Discoveries from four decades of study in San Francisco Bay: Reviews of Geophysics, v. 50, no. 4, 33 p., https://doi.org/10.1029/2012RG000397.

Conomos, T.J., and Peterson, D.H., 1977, Suspended particle transport and circulation in San Francisco Bay-An overview: New York, Academic Press, Estuarine Processes, p. 82-97, https://doi.org/10.1016/B978-0-12-751802-2.50014-X.

Downing, J., 2006, Twenty-five years with OBS sensors - The good, the bad, and the ugly: Continental Shelf Research, v. 26, no. 17-18, p. 2299-2318, https://doi.org/10.1016/j.csr.2006.07.018.

Downing-Kunz, M., Work, P., and Shellenbarger, G., 2015, Record-high specific conductance and temperature in San Francisco Bay during water year 2014: U.S. Geological Survey Open-File Report 2015-1213, 4 p., https://doi.org/10.3133/ofr20151213.

Druine, F., Verney, R., Deloffre, J., Lemoine, J.-P., Chapalain, M., Landemaine, V., and Lafite, R., 2018, In situ high frequency long term measurements of suspended sediment concentration in turbid estuarine system (Seine Estuary, France) - Optical turbidity sensors response to suspended sediment characteristics: Marine Geology, v. 400, p. 24-37, https://doi.org/10.1016/j.margeo.2018.03.003. 
Geyer, W.R., and MacCready, P., 2014, The estuarine circulation: Annual Review of Fluid Mechanics, v. 46, no. 1, p. 175-197, https://doi.org/10.1146/annurev-fluid-010313-141302.

Griffin, D., and Anchukaitis, K.J., 2014, How unusual is the 2012-2014 California drought?: Geophysical Research Letters, v. 41, no. 24, p. 9017-9023, https://doi.org/10.1002/2014GL062433.

Guy, H.P., 1969, Laboratory theory and methods for sediment analysis: U.S. Geological Survey Techniques of Water-Resources Investigations, book 5, chap. C1, 58 p., https://doi.org/10.3133/twri05C1.

Helsel, D.R., and Hirsch, R.M., 2002, Statistical methods in water resources: U.S. Geological Survey Techniques and Methods, book 4, chap. A3, https://doi.org/10.3133/tm4A3.

International Organization for Standardization, 1999, Water quality-Determination of turbidity: Geneva, Switzerland, International Organization for Standardization, ISO 7027, 10 p., https://www.iso.org/standard/30123.html.

McKee, L.J., Ganju, N.K., and Schoellhamer, D.H., 2006, Estimates of suspended sediment entering San Francisco Bay from the Sacramento and San Joaquin Delta, San Francisco Bay, California: Journal of Hydrology (Amsterdam), v. 323, no. 1-4, p. 335-352, https://doi.org/10.1016/j.jhydrol.2005.09.006.

McKee, L.J., Lewicki, M., Schoellhamer, D.H., and Ganju, N.K., 2013, Comparison of sediment supply to San Francisco Bay from watersheds draining the Bay Area and the Central Valley of California: Marine Geology, v. 345, p. 47-62, https://doi.org/10.1016/j.margeo.2013.03.003.

Rasmussen, P.P., Gray, J.R., Glysson, G.D., and Ziegler, A.C., 2009, Guidelines and procedures for computing time-series suspended-sediment concentrations and loads from in-stream turbidity-sensor and streamflow data: U.S. Geological Survey Techniques and Methods, book 3, chap. C4, 53 p., https://pubs.usgs.gov/tm/tm3c4/.

Schoellhamer, D.H., 2011, Sudden clearing of estuarine waters upon crossing the threshold from transport to supply regulation of sediment transport as an erodible sediment pool is depleted-San Francisco Bay, 1999: Estuaries and Coasts, v. 34, no. 5, p. 885-899, https://doi.org/10.1007/s12237-011-9382-x.
Schoellhamer, D., McKee, L., Pearce, S., Kauhanen, P., Salomon, M., Dusterhoff, S., Grenier, L., Marineau, M., and Trowbridge, P., 2018, Sediment supply to San Francisco Bay, water years 1995 through 2016-Data, trends, and monitoring recommendations to support decisions about water quality, tidal wetlands, and resilience to sea level rise: Richmond, CA, San Francisco Estuary Institute, Contribution Number 842, https://www.sfei.org/ sites/default/files/biblio_files/Sediment $\% 20$ Supply $\% 20$ Synthesis\%20Report\%202017\%20-\%202018-06-11.pdf.

Shellenbarger, G., and Schoellhamer, D.H., 2011, Continuous salinity and temperature data from San Francisco estuary, 1982-2002-Trends and the salinity-freshwater inflow relationship: Journal of Coastal Research, v. 27, no. 6, p. 1191-1201, https://doi.org/10.2112/JCOASTRES-D-10-00113.1.

Smith, L.H., 1987, A review of circulation and mixing studies of San Francisco Bay, California: U.S. Geological Survey Circular 1015, 38 p., https://doi.org/10.3133/cir1015.

State of California, 2018, Bay Area census: Metropolitan Transportation Commission and the Association of Bay Area Governments, 1 p., accessed October 30, 2018, http://www.bayareacensus.ca.gov/.

U.S. Geological Survey, 2016, Policy and guidance for approval of surrogate regression models for computation of time series suspended-sediment concentration and loads: Office of Surface Water Technical Memoranda 2016.07 and 2016.10, 40 p., https://water.usgs.gov/admin/memo/SW/ sw.2016.07+wq.2016.10.pdf.

U.S. Geological Survey, 2019, National Water Information System: U.S. Geological Survey Web interface, https://doi.org/10.5066/F7P55KJN.

Wagner, R.J., Boulger, R.W., Jr., Oblinger, C.J., and Smith, B.A., 2006, Guidelines and standard procedures for continuous water-quality monitors-Station operation, record computation, and data reporting: U.S. Geological Survey Techniques and Methods, book 1, chap. D3, 51 p., https://doi.org/10.3133/tm1D3.

Wilde, F.D., Sandstrom, M.W., and Skrobialowski, S.C., 2014, Selection of equipment for water sampling (ver. 3.1): U.S. Geological Survey Techniques of Water-Resources Investigations, book 9, chap. A2, accessed July 7, 2019, at https://doi.org/10.3133/twri09A2.

Work, P.A., Downing-Kunz, M., and Livsey, D.N., 2017, Record-high specific conductance and water temperature in San Francisco Bay during water year 2015: U.S. Geological Survey Open-File Report 2017-1022, 4 p., https://doi.org/10.3133/ofr20171022. 


\section{Appendix 1 Model Archive Summaries for Suspended-Sediment Concentrations at San Francisco Bay Monitoring Stations, Water Year 2017}

In this section, details related to the regression model development for each suspended-sediment concentration record are presented according to U.S. Geological Survey (USGS) methods (U.S. Geological Survey, 2016). The term "model" is used in lieu of "equation" in accordance with USGS standards (U.S. Geological Survey, 2016). Text describing the model development applying to all sites is provided in this appendix. Unless otherwise noted, each model summary documents the suspended-sediment concentration (SSC) model developed to compute 15-minute SSC from October 1, 2016, onward. The start date of October 1, 2016, was chosen because models after October 1, 2016, comply with the USGS requirements (U.S. Geological Survey, 2016). The reader is referred to U.S. Geological Survey (2016) for model revision and updating guidelines. Sensor elevations above the bed are reported in the USGS National Water Information System (U.S. Geological Survey, 2019); in this report, sensor elevations are reported below mean lower low water to provide a common datum for inter-site comparisons. See table 1 of the main report for sensor elevations referenced from the bed and from mean lower low water.

\section{Model Inputs and Development}

All data were collected using U.S. Geological Survey protocols and are stored in the National Water Information System (NWIS) database (U.S. Geological Survey, 2019). Suspended-sediment samples were collected throughout the range of continuously observed hydrologic and turbidity conditions. Suspended-sediment samples were collected using a point sampler at the same elevation as that of the turbidity sensor.

Summary statistics and the complete model-calibration data are provided separately for each site in this appendix. Regression diagnostics, including studentized residuals, Cook's distance, leverage, and DFFITS, were computed to identify potential outliers (see Helsel and Hirsch, 2002). Observations outside of regression diagnostic criteria ranges were flagged and investigated as potential outliers. The threshold for studentized residuals was taken to be \pm 3 . Equations from Helsel and Hirsch (2002) were used to compute threshold values for leverage and DFFITS. The threshold for Cook's distance is computed as 3 times the average value of the observed Cook's distance values. Investigation of seasonality in the relation between turbidity and SSC was limited for most sites because of a paucity of data. Cross-validation of model results (U.S. Geological Survey, 2016) was used to evaluate the predictive performance of the model.

\section{Continuous Suspended-Sediment Concentration Records}

Nearly continuous (15-minute) SSC records were computed using turbidity as the only explanatory variable. The use of turbidity as an explanatory variable is appropriate physically and statistically. Turbidity makes sense physically because suspended sediment is composed of particles that scatter light in water. The relation between turbidity and SSC can vary because suspended organic particles increase turbidity but are not included in the SSC analysis. The continuous SSC records were computed from the turbidity records using regression models from October 1, 2016, onward. Data were computed at 15-minute intervals. The complete water-quality record can be found at U.S. Geological Survey (2019).

\section{Model Development}

The methods used follow USGS guidance (Rasmussen and others, 2009; U.S. Geological Survey, 2016). Regression analysis was done using Matlab ${ }^{\circledR}$ by examining turbidity as an explanatory variable for estimating suspended-sediment concentration. Three models that relate continuous turbidity and discrete SSC were considered: linear ordinary least squares regression, log-transformed ordinary least squares regression, and non-parametric Kendall-Theil regression (see Helsel and Hirsch, 2002). Log-transformed equations must be retransformed to compute SSC in linear units. The log-transformed model equation takes the form $\log _{10}(\mathrm{SSC})=\mathrm{m} \times \log _{10}$ (Turbidity) $\times 10^{\mathrm{b}} \times \mathrm{BCF}$, where $\mathrm{m}$ is the model slope, $\mathrm{b}$ is the model intercept, and $\mathrm{BCF}$ is the "bias correction factor." The bias correction factor $\mathrm{BCF}$ ) accounts for the bias introduced during retransformation back to linear space and is computed as the mean of the antilog of the residuals from the log-transformed equation (Helsel and Hirsh, 2002) with a typical value near one. In this work, equations for log-transformed models are presented as the retransformed equation in linear space: $\mathrm{SSC}=\mathrm{c} \times$ Turbiditym, where $\mathrm{c}=10^{\mathrm{b}} \mathrm{x}$ BCF. Supporting tables (tables 1.21, 1.27, 1.33, 1.39, and 1.57) present values of $\mathrm{m}, \mathrm{b}$, and $\mathrm{BCF}$. 
Model coefficients of determination (adjusted $\mathrm{R}^{2}$ ), model standard percentage error (MSPE), and model residuals were inspected to determine the most appropriate model for computing SSC. The distribution of residuals was examined for normality. Plots of residuals (the difference between the measured and computed values) as compared to computed SSC were examined for homoscedasticity (meaning that their departures from zero did not change substantially over the range of computed values). Values for all the statistics and metrics were computed and are included in each section that follows along with all relevant sample data and detailed statistical information.

\section{Suisun Bay at Mallard Island, Calif., Station 11185185; Two Sensor elevations}

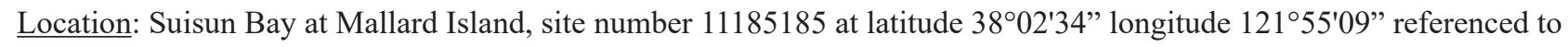
North American Datum of 1927, Contra Costa County, Calif., Hydrologic Unit 18050001, unsurveyed, at northwest corner of pier next to an equipment shelter. This site is on the left bank about 8.0 kilometers downstream from the confluence of the Sacramento and San Joaquin Rivers, at the northern shore of Mallard Island near the eastern boundary of Honker Bay, a subembayment of Suisun Bay. A concrete equipment shelter was constructed in the early 1980s by the California Department of Water Resources. A quarter-mile long walkway connects the shelter to the levee road. The station is accessed by vehicle. Tides are semidiurnal, range about 1.5 meters $(\mathrm{m})$, and follow a 14-day spring-neap cycle. Tidal currents reverse direction twice a day, and maximum speeds ranging from 0.2 meters per second $(\mathrm{m} / \mathrm{s})$ in shallow water to more than $1 \mathrm{~m} / \mathrm{s}$ in deep channels. Mean lower low water (MLLW) depth is about $7.6 \mathrm{~m}$.

Equipment: DTS-12 turbidity sensors manufactured by Forest Technologies Systems (Victoria, British Columbia, Canada) are deployed at two depths: near-surface ( $1 \mathrm{~m}$ below water surface, attached to a float) or "upper," and near-bottom (6.1 $\mathrm{m}$ below MLLW at $1.5 \mathrm{~m}$ above bottom) or "lower." Parameter is measured every five minutes; an average of three 5-minute values every 15 minutes is calculated and reported. The sensors are suspended in the water column using synthetic deployment line attached to a stainless-steel cable suspended vertically from a galvanized metal davit mounted on the pier and attached to weight resting on the bed. Each sensor is equipped with a communication cable that connects sensors to a datalogger (CR10 from Campbell Scientific, Logan, Utah) connected to cellular modem that allows for telemetry of data. The near-surface sensor is attached to a polyvinyl chloride (PVC) float and carriage assembly that moves up and down the suspension line during tidal cycles to maintain the near-surface sensor at $1 \mathrm{~m}$ below the water surface. Sensors were installed on February 8, 1994.

Water samples for SSC analysis were collected using a Van Dorn sampler at the same elevation as that of the turbidity sensor. Cross-section surveys were not done at this site because of the substantial horizontal and vertical variability in cross-section SSC.

\section{Model Summary for Suspended-Sediment Concentration at Station 11185185, Suisun Bay at Mallard Island, Calif., Depth of 1.0 Meter from Water Surface ("Upper")}

The regression model is based on 25 paired measurements of suspended-sediment concentration against concurrent turbidity samples collected from May 3, 2011, through September 30, 2017. Values outside of regression diagnostic criteria ranges (table 1.4) were flagged (table 1.5) and investigated as potential outliers.

The final regression analysis to estimate suspended-sediment concentration at site number 11185185 "upper" provided the following model:

$$
S S C=0.84 \times T U R B+8.47
$$

where
SSC is the suspended-sediment concentration, in milligrams per liter $(\mathrm{mg} / \mathrm{L})$, and
TURB is the turbidity in formazin nephelometric units (FNU).

The data and analyses used to develop the suspended-sediment concentration model for this site are summarized in tables and figures in this section (tables 1.1 to 1.6 ; figs. 1.1 to 1.4). 
Table 1.1. Previous and current suspended-sediment concentration models for station 11185185, Suisun Bay at Mallard Island, Calif., at an elevation of 1.0 meter below water surface ("upper").

[SSC: suspended-sediment concentration in milligram per liter (80154); TURB: turbidity in formazin nephelometric units (63680)]

\begin{tabular}{cll}
\hline \multicolumn{1}{c}{ Start date } & \multicolumn{1}{c}{ End date } & \multicolumn{1}{c}{ Model } \\
\hline Oct. 01, 2015 & Sept. 30, 2016 & $\mathrm{SSC}=0.83 \times \mathrm{TURB}+8.97$ \\
Oct. 01, 2016 & Ongoing & $\mathrm{SSC}=0.84 \times \mathrm{TURB}+8.47$ \\
\hline
\end{tabular}
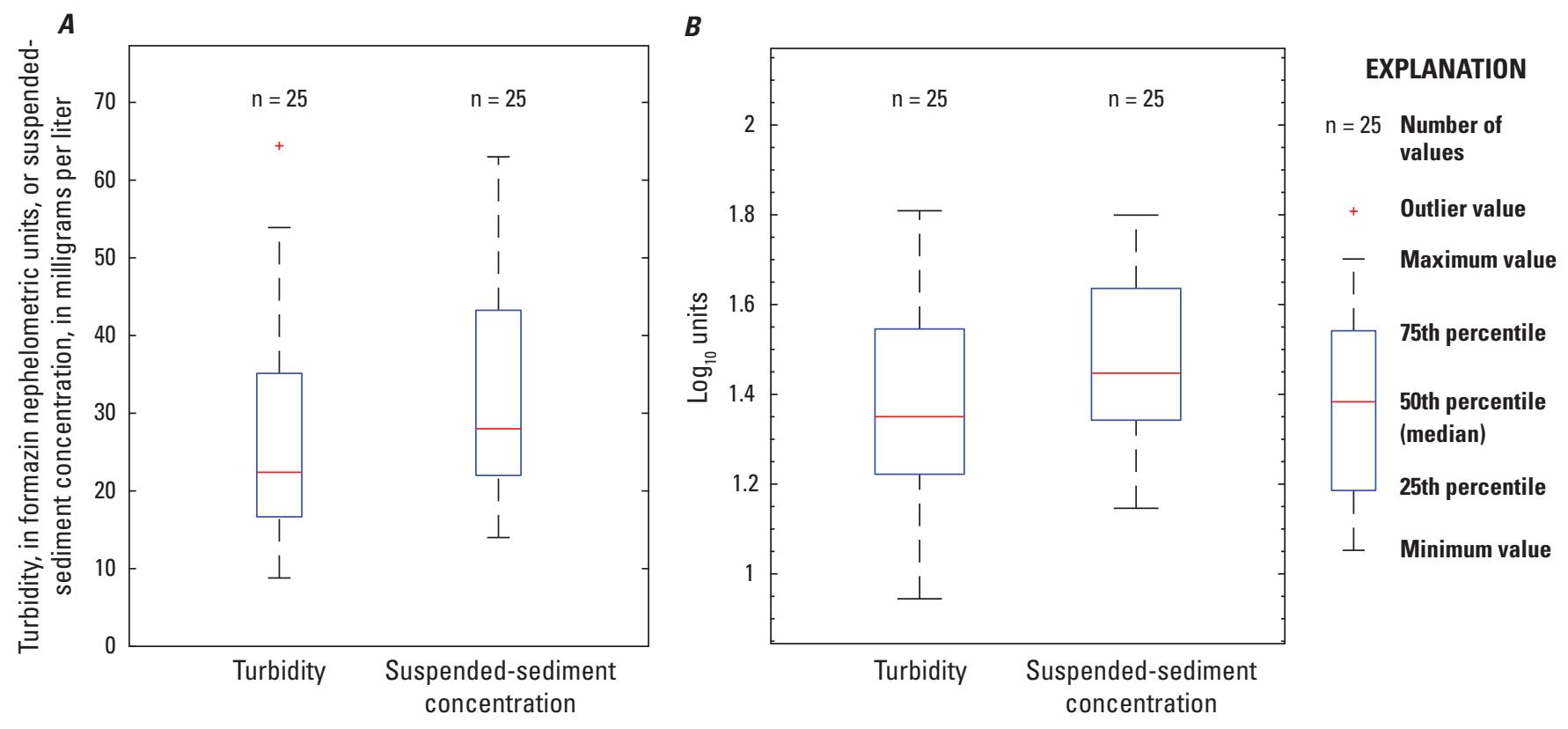

Figure 1.1. Distribution of model variable values for data from station 11185185, Suisun Bay at Mallard Island, Calif., elevation of 1.0 meter below water surface ("upper"), in $A$, linear units, and $B$, log-transformed units. Data from May 2011 to September 2017 were used. 

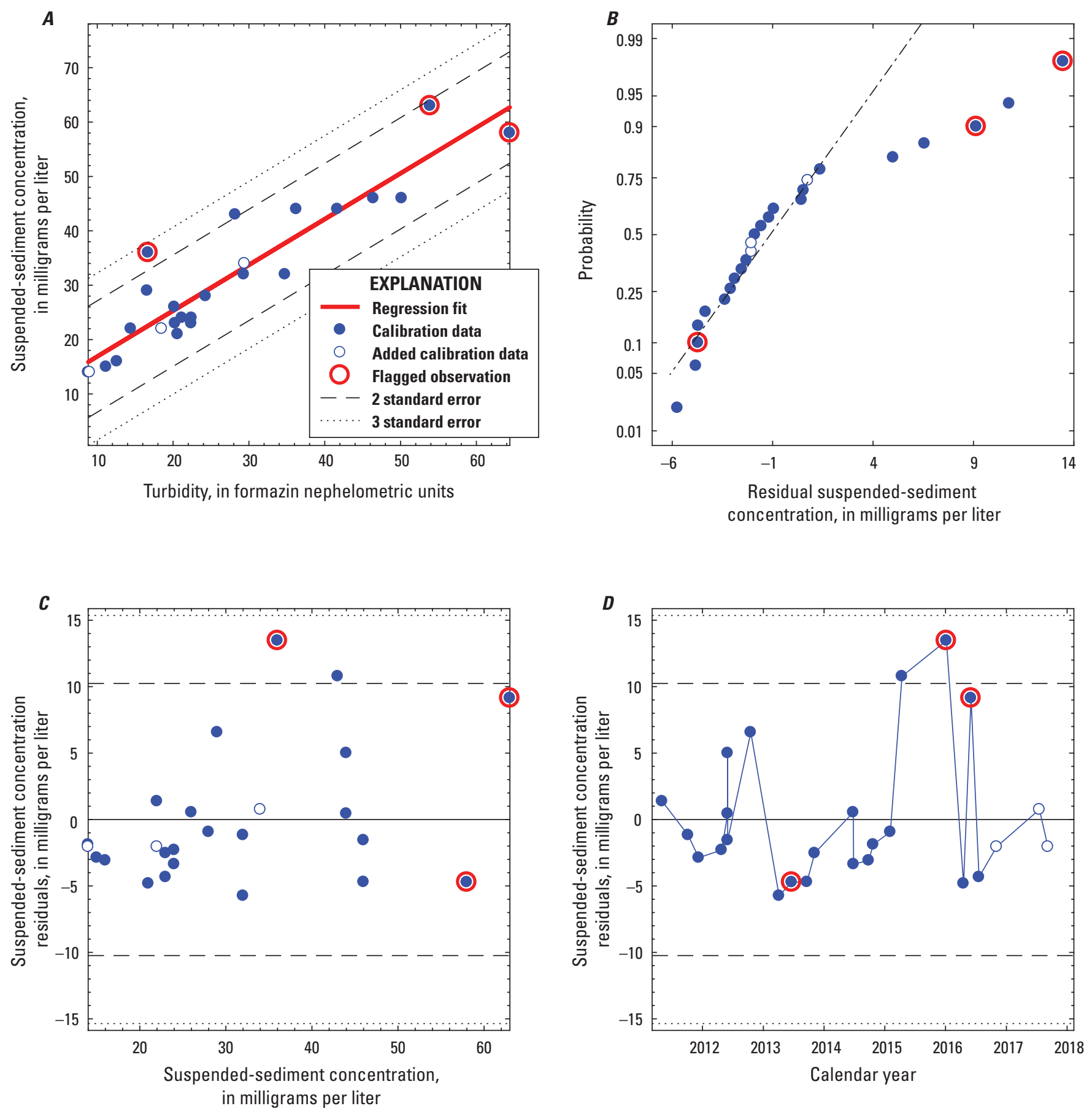

Figure 1.2. Assessment and analyses of model data for station 11185185, Suisun Bay at Mallard Island, Calif., elevation of 1.0 meter below water surface ("upper"): $A$, model calibration data and regression; $B$, normal quantile plot of model residuals; $C$, model residuals plotted against suspended-sediment concentrations (SSC); and D, model residual time series. Data were utilized from May 2011 to September 2017. 


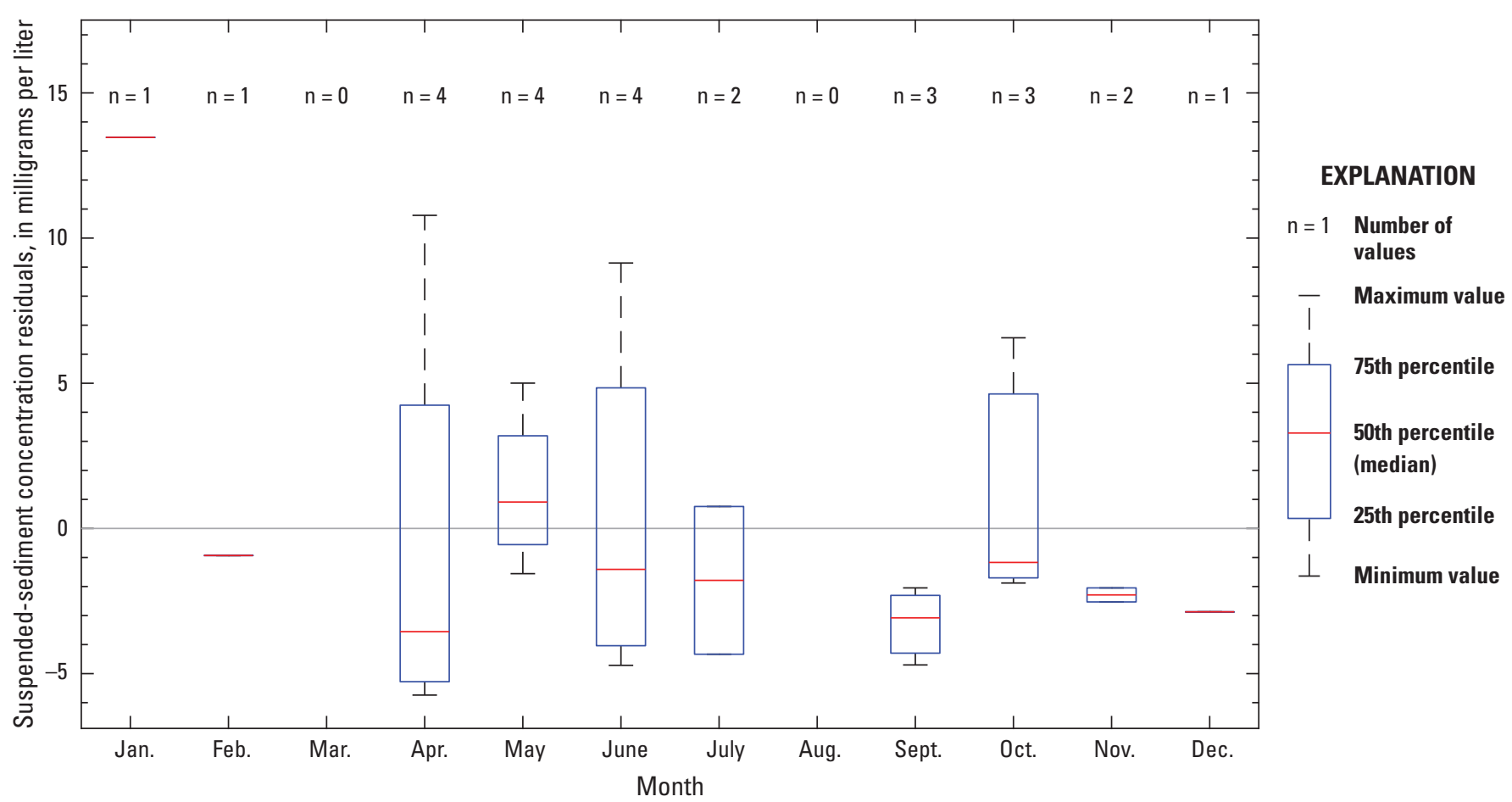

Figure 1.3. Distribution of model residuals by month for data from station 11185185, Suisun Bay at Mallard Island, Calif., elevation of 1.0 meter below water surface ("upper"). Data were utilized from May 2011 to September 2017.
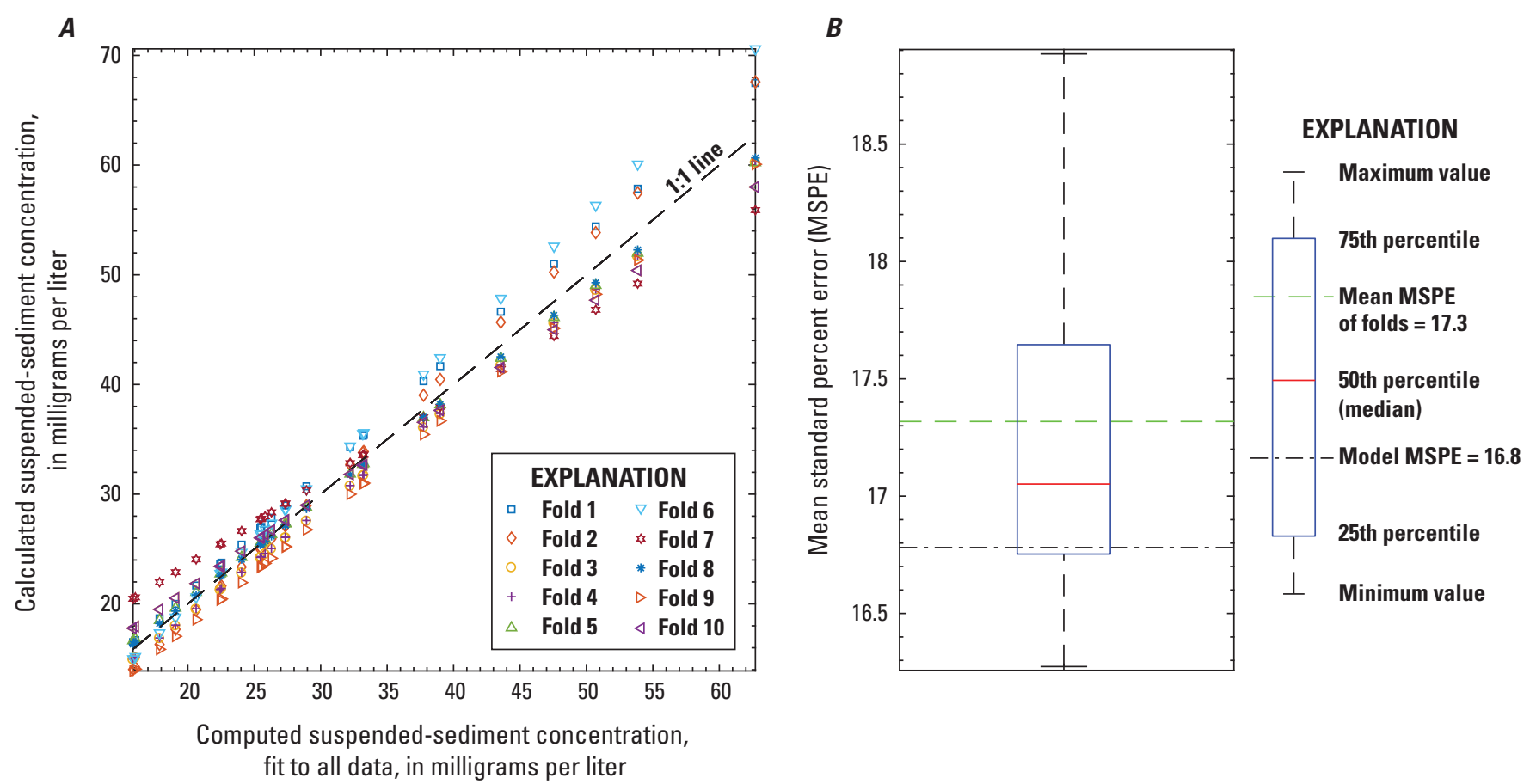

Figure 1.4. Cross-validation of model using varying subsets of data from station 11185185, Suisun Bay at Mallard Island, Calif., elevation of 1.0 meter below water surface ("upper"): $A$, calculated suspended-sediment concentration (SSC) from cross-validation by model data subsets compared to SSC computed from model fit to all data; $B$, distribution of cross-validation subset mean standard percent error (MSPE) compared to MSPE of model fit to all data. Data were utilized from May 2011 to September 2017. 
Table 1.2. Basic regression statistics for data from May 2011 to September 2017 at station 11185185, Suisun Bay at Mallard Island, Calif., from an elevation of 1.0 meter below water surface ("upper").

\begin{tabular}{lc}
\hline \multicolumn{1}{c}{ Number of observations } & $\mathbf{2 5}$ \\
\hline Standard error (RMSE) & 5.23 \\
Model standard percentage error (MSPE) & 16.8 \\
Coefficient of determination (R²) & 0.85 \\
Adjusted R2 (Adj. R2) & 0.85 \\
\hline
\end{tabular}

Table 1.3. Explanatory variables, coefficients, and statistics for selected regression modelfor station 11185185, Suisun Bay at Mallard Island, Calif., from an elevation of 1.0 meter below water surface ("upper").

\begin{tabular}{ccccc}
\hline Variable & Coefficient & Standard error & t-value & p-value \\
\hline Intercept & 8.47 & 2.22 & 3.82 & $8.8 \mathrm{E}-04$ \\
Turbidity & 0.84 & 0.07 & 11.60 & $4.4 \mathrm{E}-11$ \\
\hline
\end{tabular}

Table 1.4. Flagged observation criteria for data from May 2011 to September 2017 at station 11185185, Suisun Bay at Mallard Island, Calif., from an elevation of 1.0 meter below water surface ("upper").

[Cook's D, Cook's distance; \pm , plus or minus]

\begin{tabular}{cccc}
\hline Studentized residual & Leverage & Cooks' D & DFFITS \\
\hline \pm 3 & 0.24 & 0.16 & 0.57 \\
\hline
\end{tabular}

Table 1.5. Flagged observations for data from May 2011 to September 2017 at station 11185185, Suisun Bay at Mallard Island, Calif., from an elevation of 1.0 meter below water surface ("upper").

[mm/dd/yyy, month/day/year; hh:mm, hour:minute; FNU, formazin nephelometric units;

SSC, suspended-sediment concentrations; mg/l, milligrams per liter; Cook's D, Cook's distance]

\begin{tabular}{lcccccc}
\hline $\begin{array}{c}\text { Time } \\
\text { (mm/dd/yyyy hh:mm) }\end{array}$ & $\begin{array}{c}\text { Turbidity } \\
\text { (FNU) }\end{array}$ & $\begin{array}{c}\text { SSC } \\
\text { (mg/l) }\end{array}$ & $\begin{array}{c}\text { Studentized } \\
\text { residual }\end{array}$ & Leverage & $\begin{array}{c}\text { Cooks' } \\
\text { D }\end{array}$ & DFFITS \\
\hline $06 / 20 / 201311: 25$ & 64.4 & 58 & -1.09 & 0.31 & 0.27 & -0.73 \\
$01 / 06 / 201611: 30$ & 16.7 & 36 & 3.12 & 0.06 & 0.23 & 0.79 \\
$06 / 02 / 201611: 45$ & 53.9 & 63 & 2.06 & 0.18 & 0.41 & 0.97 \\
\hline
\end{tabular}


Table 1.6. Suspended-sediment concentration model-calibration dataset from May 2011 to Sept 2017 at station 11185185, Suisun Bay at Mallard Island, Calif., from an elevation of 1.0 meter below water surface ("upper").

$[\mathrm{mm} / \mathrm{dd} / \mathrm{yyy}$, month/day/year; hh:mm, hour:minute; FNU, formazin nephelometric units; mg/l, milligrams per liter; SSC, suspended-sediment concentrations; - , no data]

\begin{tabular}{|c|c|c|c|c|c|}
\hline $\begin{array}{c}\text { Time } \\
\text { (mm/dd/yyyy hh:mm) }\end{array}$ & $\begin{array}{l}\text { Turbidity } \\
\text { (FNU) }\end{array}$ & $\begin{array}{l}\text { SSC } \\
(\mathbf{m g} / \mathrm{l})\end{array}$ & $\begin{array}{c}\text { Computed SSC } \\
(\mathrm{mg} / \mathrm{l})\end{array}$ & $\begin{array}{l}\text { Residual } \\
\text { (mg/l) }\end{array}$ & $\begin{array}{l}\text { Censored } \\
\text { value }\end{array}$ \\
\hline 05/03/2011 11:30 & 14.4 & 22 & 20.6 & 1.4 & - \\
\hline 10/06/2011 10:45 & 29.3 & 32 & 33.2 & -1.2 & - \\
\hline 12/09/2011 12:00 & 11.2 & 15 & 17.9 & -2.9 & - \\
\hline 04/25/2012 12:25 & 21.2 & 24 & 26.3 & -2.3 & - \\
\hline 05/31/2012 12:55 & 41.7 & 44 & 43.6 & 0.4 & - \\
\hline 05/31/2012 13:05 & 36.3 & 44 & 39 & 5.0 & - \\
\hline 05/31/2012 13:15 & 46.4 & 46 & 47.6 & -1.6 & - \\
\hline 10/17/2012 11:15 & 16.6 & 29 & 22.4 & 6.6 & - \\
\hline 04/05/2013 11:15 & 34.8 & 32 & 37.7 & -5.7 & - \\
\hline 06/20/2013 11:25 & 64.4 & 58 & 62.7 & -4.7 & - \\
\hline 09/20/2013 12:15 & 50.2 & 46 & 50.7 & -4.7 & - \\
\hline $11 / 05 / 2013 \quad 12: 35$ & 20.3 & 23 & 25.5 & -2.5 & - \\
\hline 06/25/2014 9:45 & 20.2 & 26 & 25.5 & 0.5 & - \\
\hline 06/27/2014 10:30 & 22.4 & 24 & 27.4 & -3.4 & - \\
\hline 09/26/2014 12:10 & 12.6 & 16 & 19.1 & -3.1 & - \\
\hline 10/23/2014 12:15 & 8.8 & 14 & 15.9 & -1.9 & - \\
\hline 02/03/2015 11:45 & 24.3 & 28 & 28.9 & -0.9 & - \\
\hline 04/14/2015 09:45 & 28.2 & 43 & 32.2 & 10.8 & - \\
\hline 01/06/2016 11:30 & 16.7 & 36 & 22.5 & 13.5 & - \\
\hline 04/18/2016 10:45 & 20.6 & 21 & 25.8 & -4.8 & - \\
\hline 06/02/2016 11:45 & 53.9 & 63 & 53.9 & 9.1 & - \\
\hline 07/20/2016 11:05 & 22.4 & 23 & 27.3 & -4.3 & - \\
\hline 11/03/2016 09:30 & 9.0 & 14 & 16 & -2.0 & - \\
\hline 07/18/2017 12:30 & 29.4 & 34 & 33.2 & 0.8 & - \\
\hline 09/07/2017 09:30 & 18.5 & 22 & 24 & -2.0 & - \\
\hline
\end{tabular}

Date model was created: May 18, 2018

Model calibration data period: May 3, 2011, to September 30, 2017

Model application date: October 1, 2016, onward

Analyzed by Daniel Livsey, California Water Science Center (CAWSC), May 18, 2018

Approved by Maureen Downing-Kunz, CAWSC, June 4, 2018 


\section{Model Summary for Suspended-Sediment Concentration at Station 11185185 Suisun Bay at Mallard Island, Calif., Elevation of 6.1 Meters Below Mean Lower Low Water (“Lower”)}

The regression model is based on 18 paired measurements of suspended-sediment concentration against turbidity samples collected concurrently from October 17, 2012, through September 30, 2017. Values outside of regression diagnostic criteria ranges (table 1.10) were flagged (table 1.11) and investigated as potential outliers.

The final regression analysis to estimate suspended-sediment concentration at site number 11185185 "lower" resulted in the following model:

$$
S S C=1.20 \times T U R B+3.40
$$

The data and analyses used to develop the suspended-sediment concentration model for this site are summarized in tables and figures in this section (tables 1.7 to 1.12 ; figs. 1.5 to 1.8 ).

Table 1.7. Previous and current suspended-sediment concentration models for station 11185185, Suisun Bay at Mallard Island, Calif., at an elevation of 6.1 meters below mean lower low water ("lower").

[SSC: suspended-sediment concentration in milligrams per liter (80154); TURB: turbidity in formazin nephelometric units (63680)]

\begin{tabular}{cll}
\hline \multicolumn{1}{c}{ Start date } & \multicolumn{1}{c}{ End date } & \multicolumn{1}{c}{ Model } \\
\hline Oct. 01,2015 & Sept. 30,2016 & $\mathrm{SSC}=1.14 \times \mathrm{TURB}+5.38$ \\
Oct. 01,2016 & Ongoing & $\mathrm{SSC}=1.20 \times \mathrm{TURB}+3.40$ \\
\hline
\end{tabular}
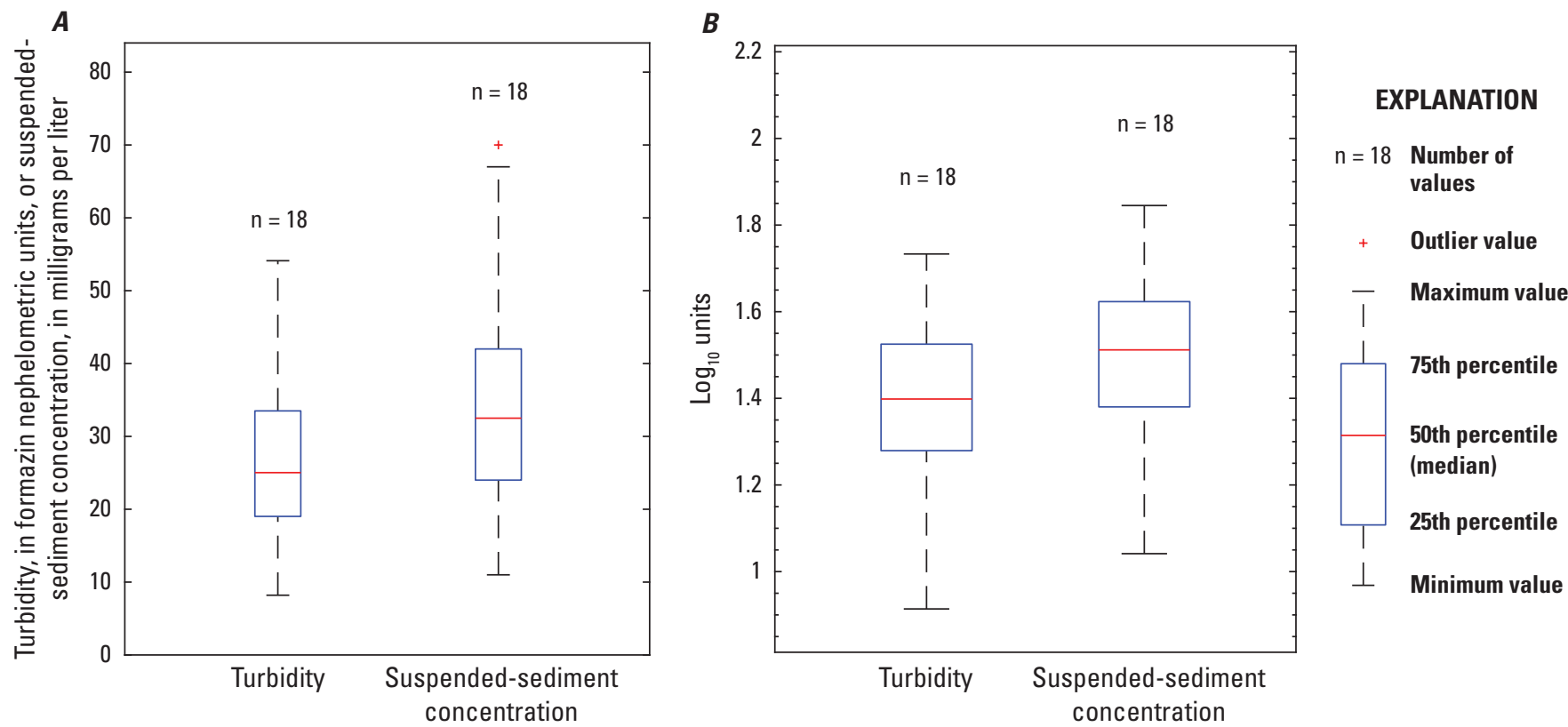

Figure 1.5. Distribution of model variable values for data from station 11185185, Suisun Bay at Mallard Island, Calif., elevation of 6.1 meters below mean lower low water ("lower") in $A$, linear units, and $B$, log-transformed units. Data from 0 ctober 2012 to September 2017 were used. 

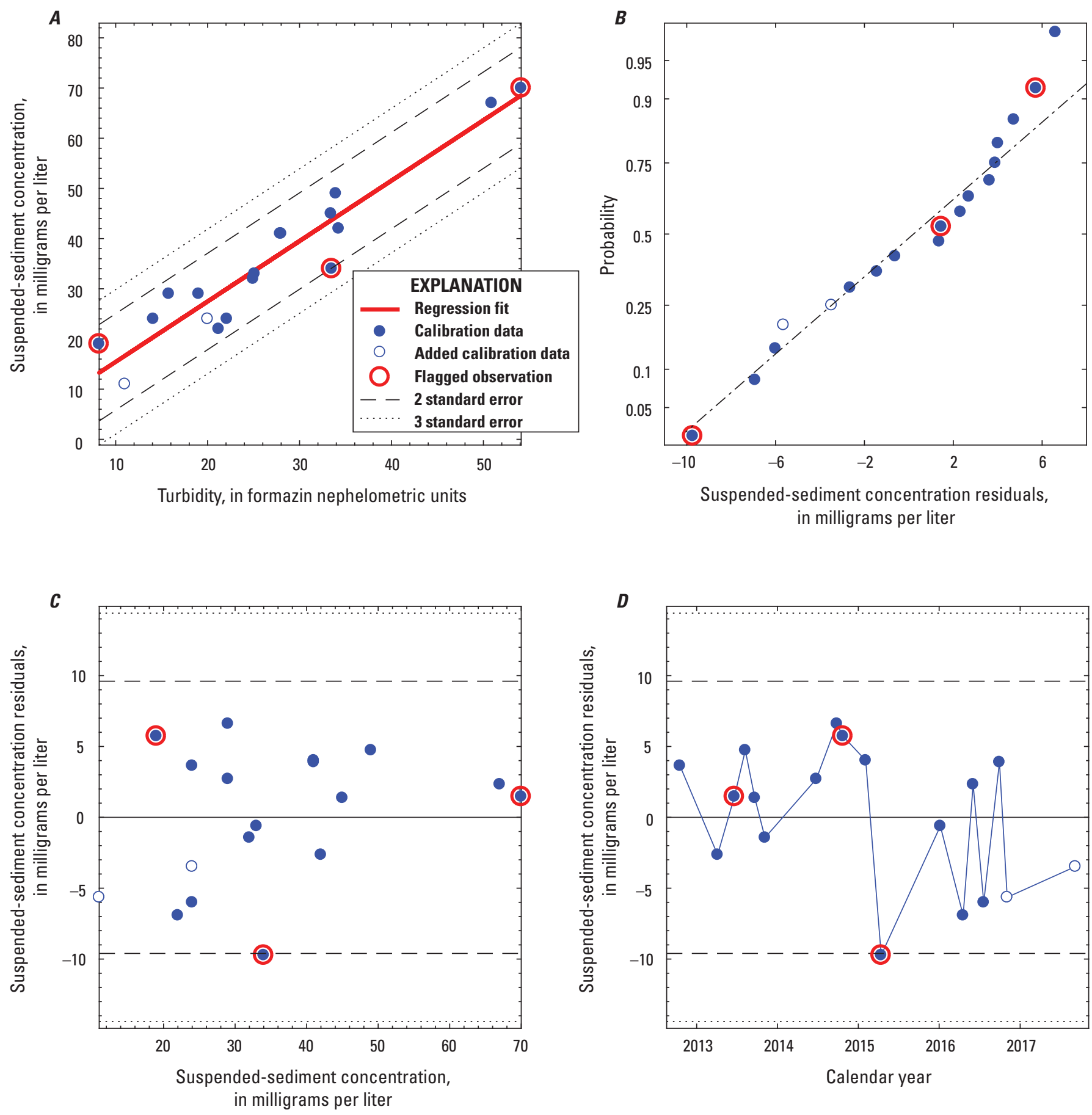

Figure 1.6. Assessment and analyses of model data for station 11185185, Suisun Bay at Mallard Island, Calif., elevation of 6.1 meters below mean lower low water (“lower"): $A$. model calibration data and regression; $B$, normal quantile plot of model residuals; $C$, model residuals plotted against suspended-sediment concentration (SSC); and D, model residual time series. Data from 0ctober 2012 to September 2017 were used. 


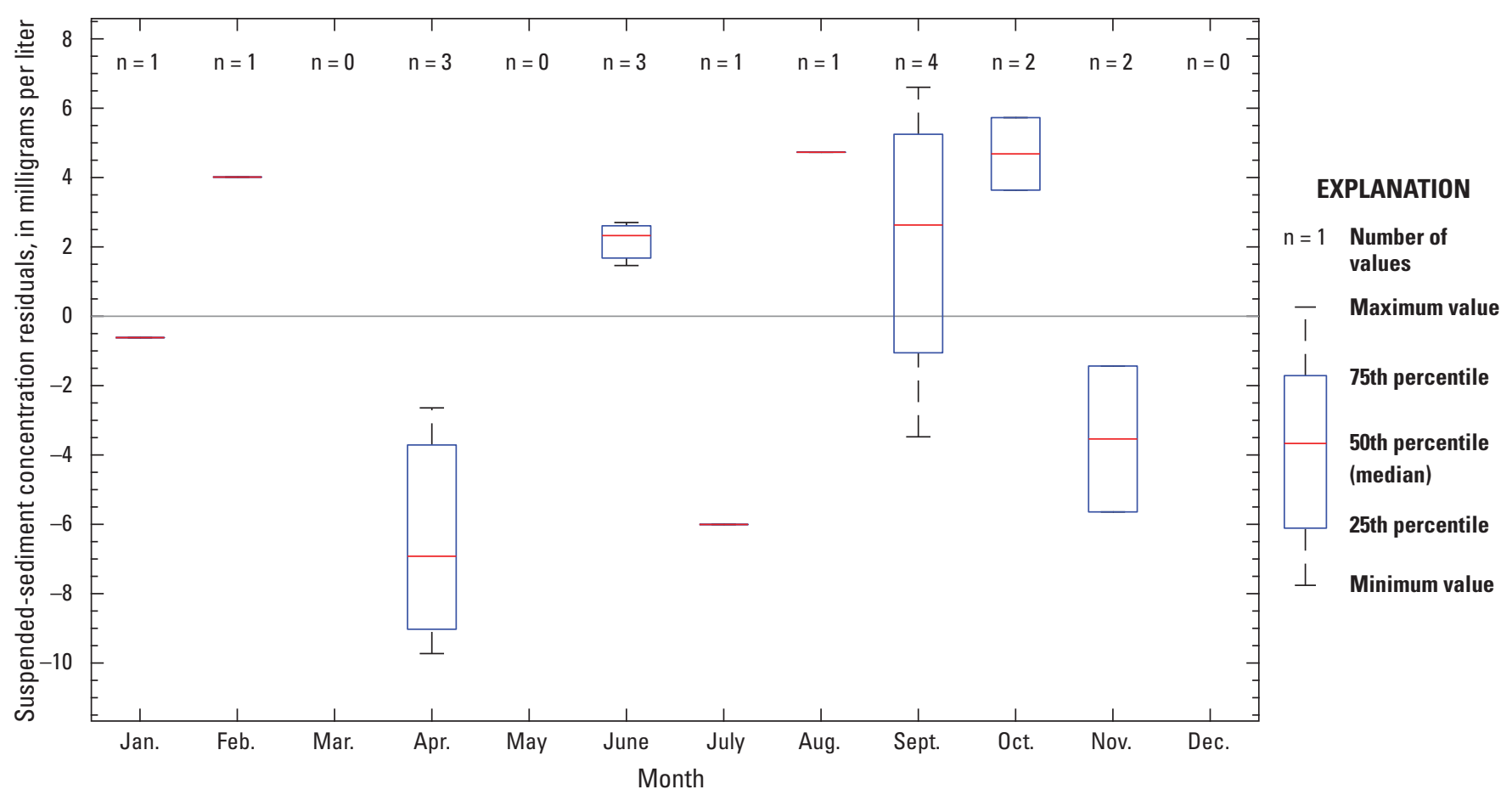

Figure 1.7. Distribution of model residuals by month for data from station 11185185, Suisun Bay at Mallard Island, Calif., elevation of 6.1 meters below mean lower low water (“lower”). Data from October 2012 to September 2017 were used.
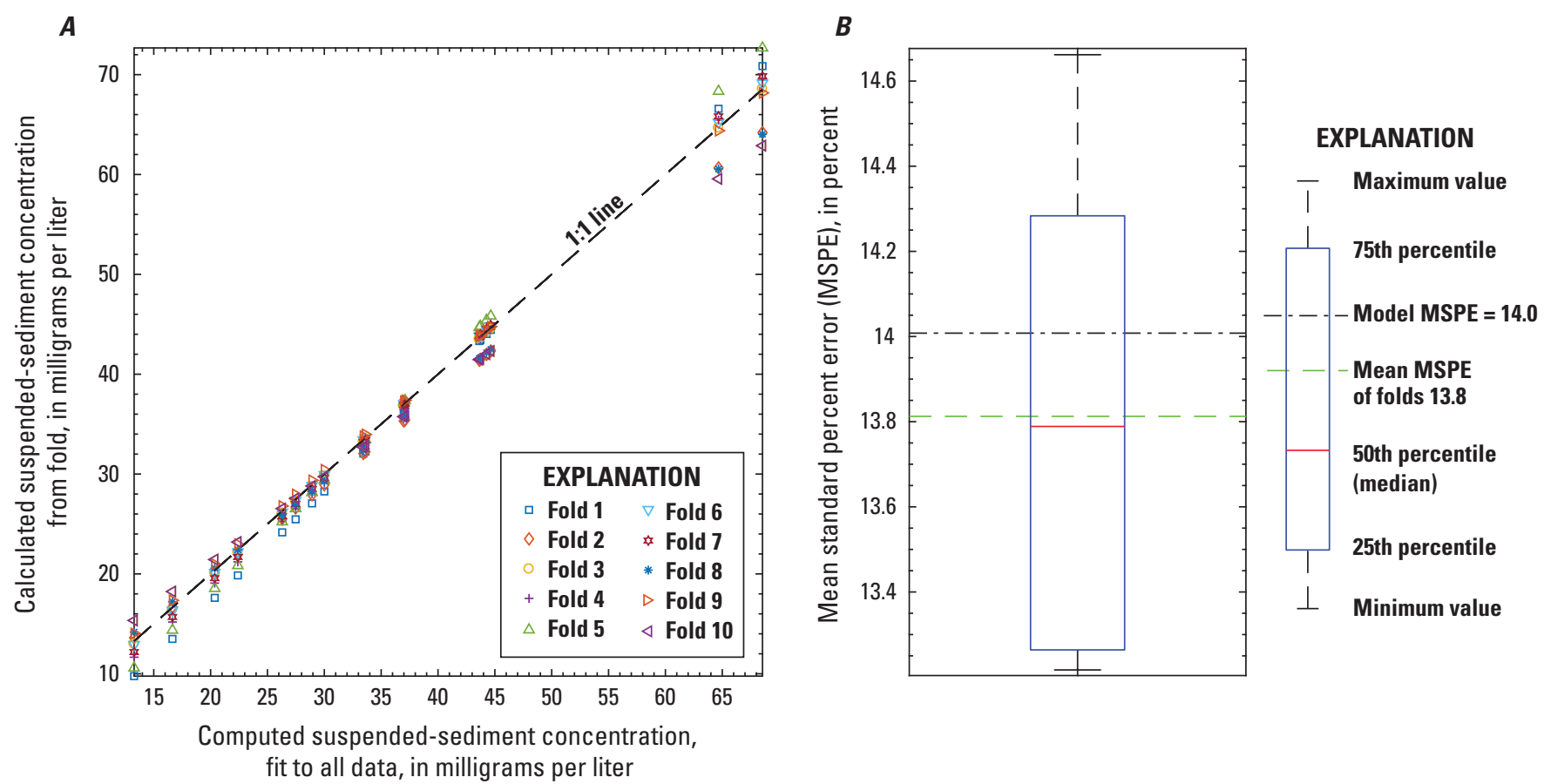

Figure 1.8. Cross-validation of model using varying subsets of for data from station 11185185, Suisun Bay at Mallard Island, Calif., elevation of 6.1 meters below mean lower low water ("lower"): $A$, calculated suspended-sediment concentration (SSC) from cross-validation by model data subsets compared to SSC computed from model fit to all data; $B$, distribution of cross-validation subset mean standard percent error (MSPE) compared to MSPE of model fit to all data. Data from October 2012 to September 2017 were used. 
Table 1.8. Basic regression statistics for data from October 2012 to September 2017 at station 11185185, Suisun Bay at Mallard Island, Calif., elevation of 6.1 meters below mean lower low water ("lower").

\begin{tabular}{lc}
\hline \multicolumn{1}{c}{ Number of observations } & $\mathbf{1 8}$ \\
\hline Standard error (RMSE) & 4.95 \\
Model standard percentage error (MSPE) & 14.0 \\
Coefficient of determination (R 2$)$ & 0.90 \\
Adjusted R2 (Adj. R2) & 0.90 \\
\hline
\end{tabular}

Table 1.9. Explanatory variables, coefficients, and statistics for selected regression model for station 11185185, Suisun Bay at Mallard Island, Calif., elevation of 6.1 meters below mean lower low water ("lower").

\begin{tabular}{lcccl}
\hline Variable & Coefficient & $\begin{array}{c}\text { Standard } \\
\text { error }\end{array}$ & t-value & p-value \\
\hline Intercept & 3.40 & 2.84 & 1.20 & 0.249 \\
Turbidity & 1.20 & 0.10 & 12.33 & $1.4 \mathrm{E}-09$ \\
\hline
\end{tabular}

Table 1.10. Flagged observation criteria for data from October 2012 to September 2017 at station 11185185, Suisun Bay at Mallard Island, Calif., elevation of 6.1 meters below mean lower low water ("lower").

[Cook's D, Cook's distance; \pm , plus or minus]

\begin{tabular}{cccc}
\hline Studentized residual & Leverage & Cooks' D & DFFITS \\
\hline \pm 3 & 0.33 & 0.17 & 0.67 \\
\hline
\end{tabular}

Table 1.11. Flagged observations for data from October 2012 to September 2017 at station 11185185, Suisun Bay at Mallard Island, Calif., elevation of 6.1 meters below mean lower low water ("lower").

[mm/dd/yyy, month/day/year; hh:mm, hour:minute; FNU, formazin nephelometric units; SSC, suspended-sediment concentration; mg/l, milligrams per liter; Cook's D, Cook's distance]

\begin{tabular}{lcrrrrr}
\hline $\begin{array}{c}\text { Time } \\
\text { (mm/dd/yyyy hh:mm) }\end{array}$ & $\begin{array}{c}\text { Turbidity } \\
\text { (FNU) }\end{array}$ & $\begin{array}{c}\text { SSC } \\
\text { (mg/l) }\end{array}$ & $\begin{array}{c}\text { Studentized } \\
\text { residual }\end{array}$ & Leverage & $\begin{array}{c}\text { Cooks' } \\
\text { D }\end{array}$ & DFFITS \\
\hline $06 / 20 / 2013$ 11:20 & 54.1 & 70 & 0.36 & 0.35 & 0.04 & 0.26 \\
10/23/2014 12:30 & 8.20 & 19 & 1.31 & 0.19 & 0.19 & 0.63 \\
$04 / 14 / 201510: 00$ & 33.5 & 34 & -2.30 & 0.07 & 0.17 & -0.65 \\
\hline
\end{tabular}


Table 1.12. Suspended-sediment concentration model-calibration dataset for data from October 2012 to September 2017 at station 11185185, Suisun Bay at Mallard Island, Calif., elevation of 6.1 meters below mean lower low water ("lower").

[mm/dd/yyy, month/day/year; hh:mm, hour:minute; FNU, formazin nephelometric units; SSC, suspended-sediment concentration; mg/l, milligrams per liter; —, not applicable]

\begin{tabular}{lccccc}
\hline $\begin{array}{c}\text { Time } \\
\text { (mm/dd/yyy hh:mm) }\end{array}$ & $\begin{array}{c}\text { Turbidity } \\
\text { (FNU) }\end{array}$ & $\begin{array}{c}\text { SSC } \\
\text { (mg/l) }\end{array}$ & $\begin{array}{c}\text { Computed SSC } \\
\text { (mg/l) }\end{array}$ & $\begin{array}{c}\text { Residual } \\
\text { (mg/l) }\end{array}$ & $\begin{array}{c}\text { Censored } \\
\text { value }\end{array}$ \\
\hline 10/17/2012 11:30 & 14.09 & 24 & 20.4 & 3.6 & - \\
04/05/2013 11:30 & 34.26 & 42 & 44.6 & -2.6 & - \\
06/20/2013 11:20 & 54.11 & 70 & 68.5 & 1.5 & - \\
08/08/2013 15:00 & 33.95 & 49 & 44.3 & 4.7 & - \\
09/20/2013 12:35 & 33.42 & 45 & 43.6 & 1.4 & - \\
11/05/2013 12:45 & 24.95 & 32 & 33.4 & -1.4 & - \\
06/25/2014 10:00 & 19.02 & 29 & 26.3 & 2.7 & - \\
09/26/2014 12:05 & 15.78 & 29 & 22.4 & 6.6 & - \\
10/23/2014 12:30 & 8.2 & 19 & 13.3 & 5.7 & - \\
02/03/2015 12:00 & 27.9 & 41 & 37 & 4.0 & - \\
04/14/2015 10:00 & 33.5 & 34 & 43.7 & -9.7 & - \\
01/06/2016 11:45 & 25.1 & 33 & 33.6 & -0.6 & - \\
04/18/2016 10:50 & 21.2 & 22 & 28.9 & -6.9 & - \\
06/02/2016 11:30 & 50.9 & 67 & 64.7 & 2.3 & - \\
$07 / 20 / 201611: 00$ & 22.1 & 24 & 30 & -6.0 & - \\
09/29/2016 11:00 & 28 & 41 & 37.1 & 3.9 & - \\
11/03/2016 09:25 & 11 & 11 & 16.6 & -5.6 & - \\
09/07/2017 09:35 & 20 & 24 & 27.5 & -3.5 & - \\
\hline
\end{tabular}

Date model was created: May 18, 2018

Model application date: October 1, 2016, onward

Analyzed by Daniel Livsey, California Water Science Center (CAWSC), May 18, 2018

Approved by Maureen Downing-Kunz, CAWSC, June 4, 2018 


\section{Suisun Bay at Benicia Bridge, Calif., Station 11455780; Two Sensor Elevations}

Location: Suisun Bay at Benicia Bridge, site number 11455780 at latitude $38^{\circ} 02^{\prime} 42^{\prime \prime}$ longitude $122^{\circ} 07^{\prime} 32^{\prime \prime}$ referenced to North American Datum of 1927, Solano County, Calif., Hydrologic Unit 18050001, unsurveyed, at north side of bridge pier 7, directly under the deck of Benicia Bridge (Interstate 680). The region near Benicia Bridge has complex hydrology especially during ebb tides due to surface flow from Suisun Bay and Grizzly Bay (a shallow subembayment of Suisun Bay) mixing at the Benicia Bridge. Equipment is housed in a 0.9-by-1.2 m environmental shelter attached to a railing on the north side of the bridge pier. The station is accessed by boat. Tides are semidiurnal, range of about $1.5 \mathrm{~m}$, and follow a 14-day spring-neap cycle. Tidal currents reverse direction twice a day, and maximum speeds range from $0.2 \mathrm{~m} / \mathrm{s}$ in shallow water to more than $1.0 \mathrm{~m} / \mathrm{s}$ in deep channels. Mean lower low water (MLLW) depth is about $24 \mathrm{~m}$ immediately surrounding the pier, but depths in the vicinity are about 18.3 MLLW.

Equipment: Multi-parameter water-quality sondes manufactured by YSI (model 6920, YSI, Burlington, Vt.) equipped with specific conductance and temperature probes (YSI model 6560), turbidity (YSI model 6136), and pressure sensor for water depth above instrument (not tied in to a reference elevation and not published) are deployed at two depths: near-surface $(0.7 \mathrm{~m}$ below MLLW) or "upper" and near-bottom (18.6 m below MLLW at $5.8 \mathrm{~m}$ above bottom) or "lower." Parameters are measured every 15 minutes; value reported is the average of a 12-second burst with a sampling rate of 2 hertz (Hz). The sensors are suspended in the water column using synthetic deployment line attached to a stainless-steel cable suspended vertically from a galvanized metal davit mounted on the pier and attached to a 91-kilogram $(\mathrm{kg})$ weight resting on the bed. Each sonde is equipped with a communication cable that connects to a datalogger (CR10X from Campbell Scientific) connected to cellular modem that allows for telemetry of data.

Water samples for SSC analysis are collected using a point sampler at the same elevation as the turbidity sensor. Cross-section surveys are not conducted at this site because of the large horizontal and vertical variability in cross-section SSC.

\section{Model Summary for Suspended-Sediment Concentration at Station 11455780 Suisun Bay at Benicia Bridge, Calif., Elevation of $2.4 \mathrm{~m}$ Below Mean Lower Low Water ("Upper")}

The regression model is based on 25 paired measurements of suspended-sediment concentration against turbidity samples collected concurrently from January 8, 2015, through September 30, 2017. Values outside of regression diagnostic criteria ranges (table 1.16) were flagged (table 1.17) and investigated as potential outliers. Data from one sample from January 8, 2015, and one from March 29, 2016, were deemed outliers and were removed from the dataset given the large influence of these data points on model regression parameters as measured by DFFITS and Cook's D.

The final regression analysis to estimate suspended-sediment concentration at site number 11455780 "upper" resulted in the following model:

$$
S S C=1.55 \times T U R B+1.89
$$

The data and analyses used to develop the suspended-sediment concentration model for this site are summarized in tables and figures in this section (tables 1.13 to 1.18 ; figs. 1.9 to 1.12 ). 
Table 1.13. Previous and current suspended-sediment concentration model for station 11455780, Suisun Bay at Benicia Bridge, Calif., at an elevation of 2.4 meters below mean lower low water ("upper").

[SSC: suspended-sediment concentration in milligrams per liter (80154); TURB: turbidity in formazin nephelometric units (63680)]

\begin{tabular}{cll}
\hline \multicolumn{1}{c}{ Start date } & \multicolumn{1}{c}{ End date } & \multicolumn{1}{c}{ Model } \\
\hline Oct. 01, 2015 & Sept. 30, 2016 & $\mathrm{SSC}=1.69 \times \mathrm{TURB}^{0.972}$ \\
Oct. 01, 2016 & Ongoing & $\mathrm{SSC}=1.55 \times \mathrm{TURB}+1.89$ \\
\hline
\end{tabular}
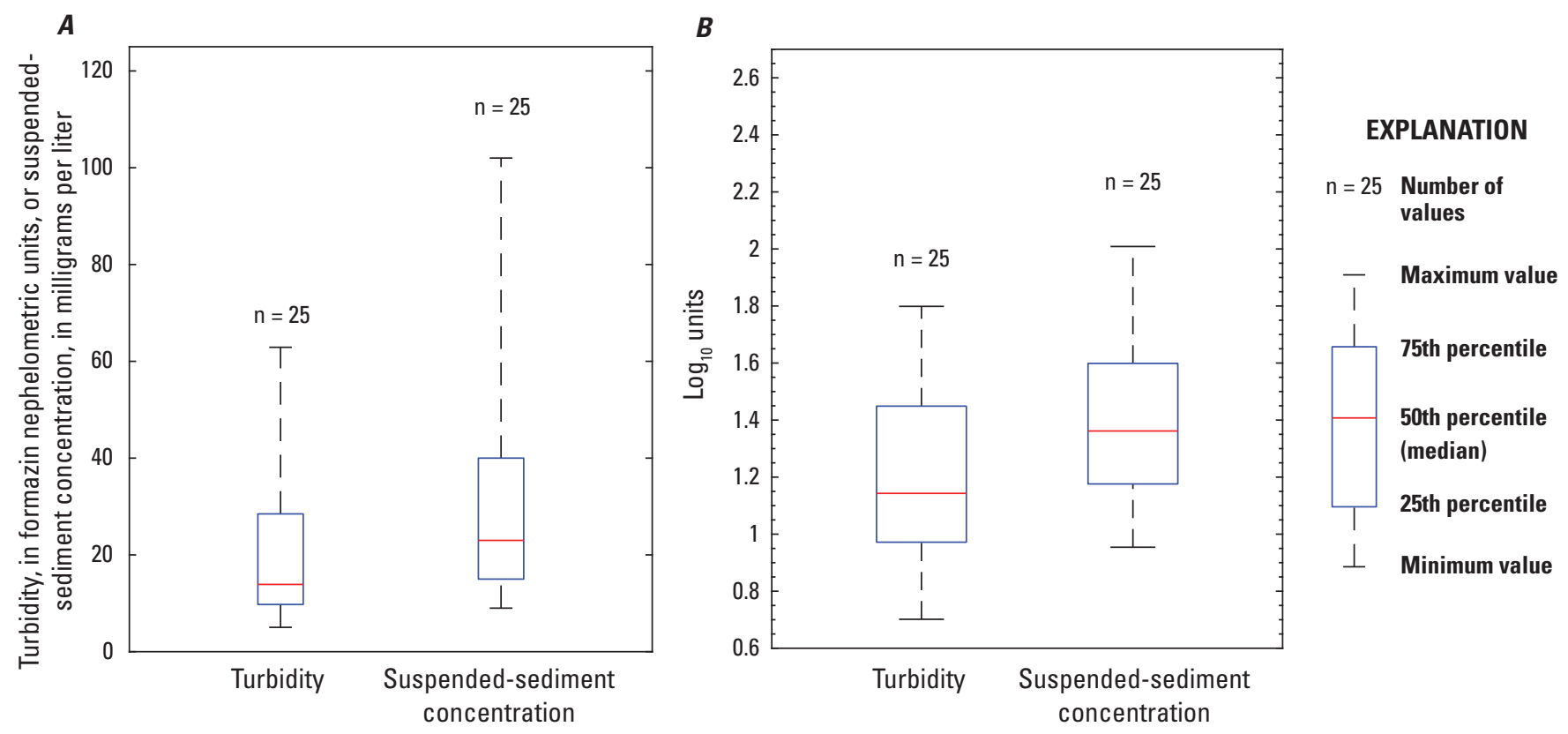

Figure 1.9. Distribution of model variable values for data from station 11455780, Suisun Bay at Benicia Bridge, Calif., at an elevation of 2.4 meters below mean lower low water ("upper") in $A$, linear units, and $B$, log-transformed units. Data from January 2015 to September 2017 were used. 

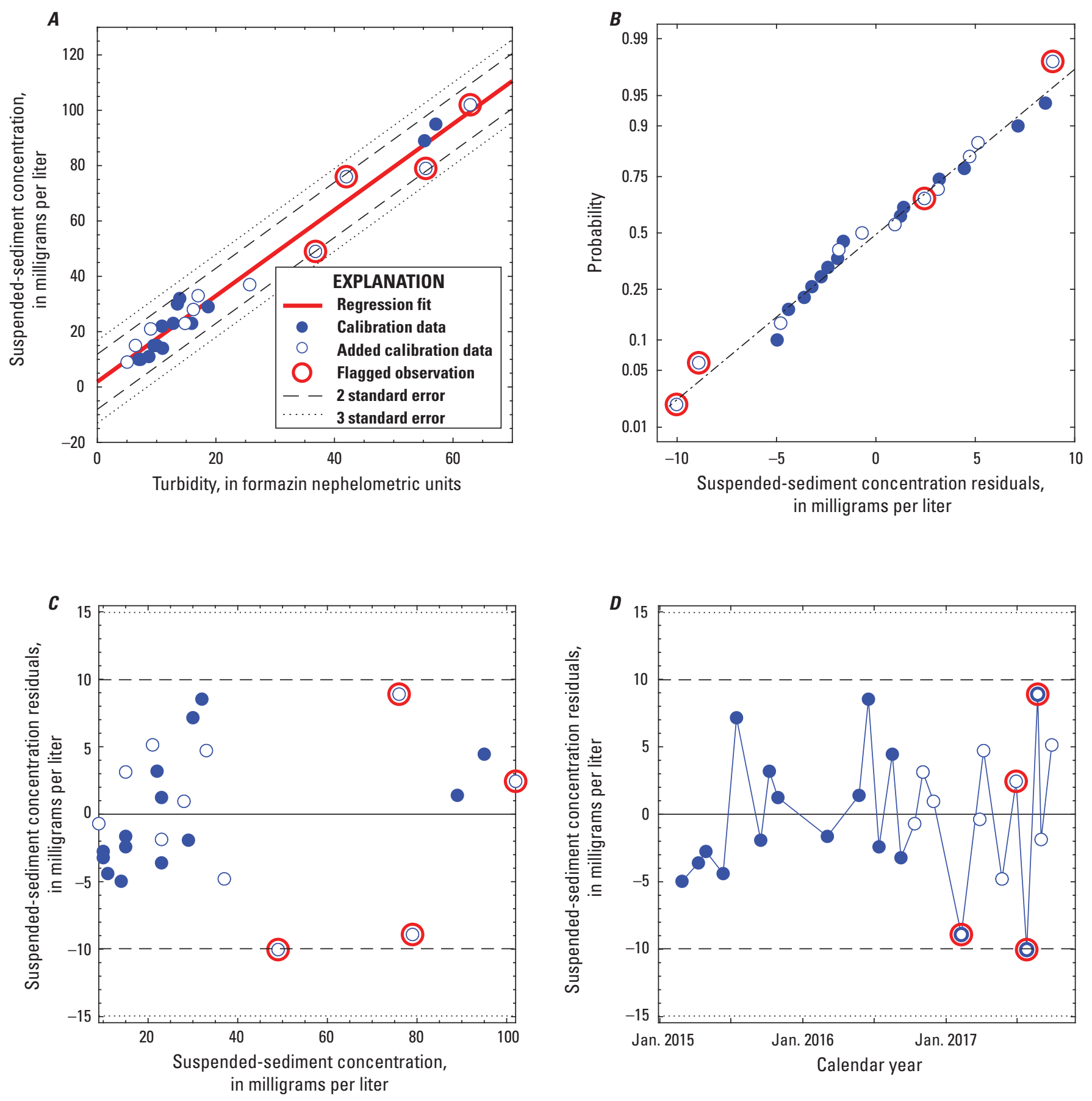

Figure 1.10. Assessment and analyses of model data for station 11455780, Suisun Bay at Benicia Bridge, Calif., at an elevation of 2.4 meters below mean lower low water ("upper"): $A$, model calibration data and regression; $B$, normal quantile plot of model residuals; $C$, model residuals plotted against suspended-sediment concentration (SSC); and $D$, model residual time series. Data from January 2015 to September 2017 were used. 


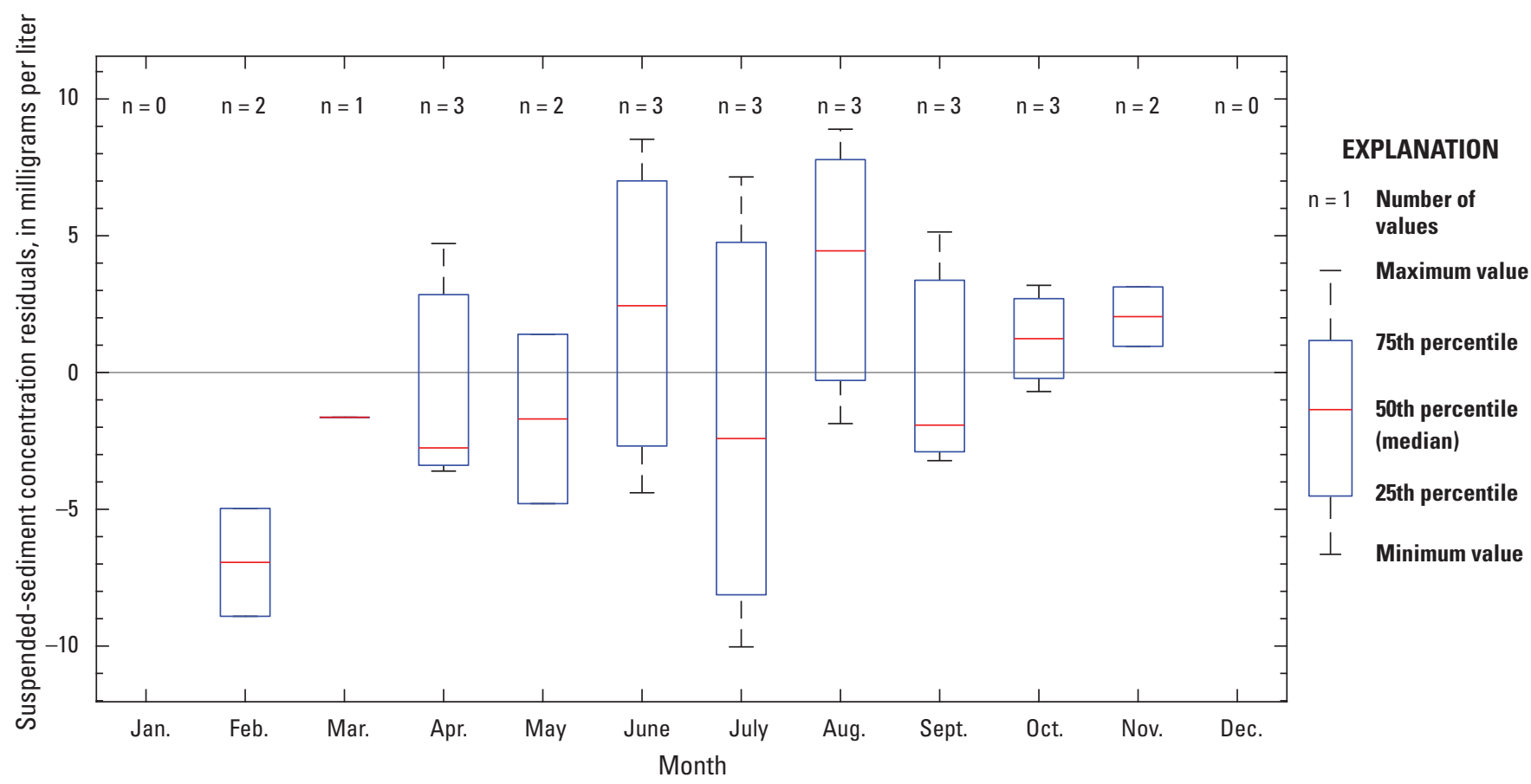

Figure 1.11. Distribution of model residuals by month for station 11455780, Suisun Bay at Benicia Bridge, Calif., at an elevation of 2.4 meters below mean lower low water ("upper"). Data from January 2015 to September 2017 were used.
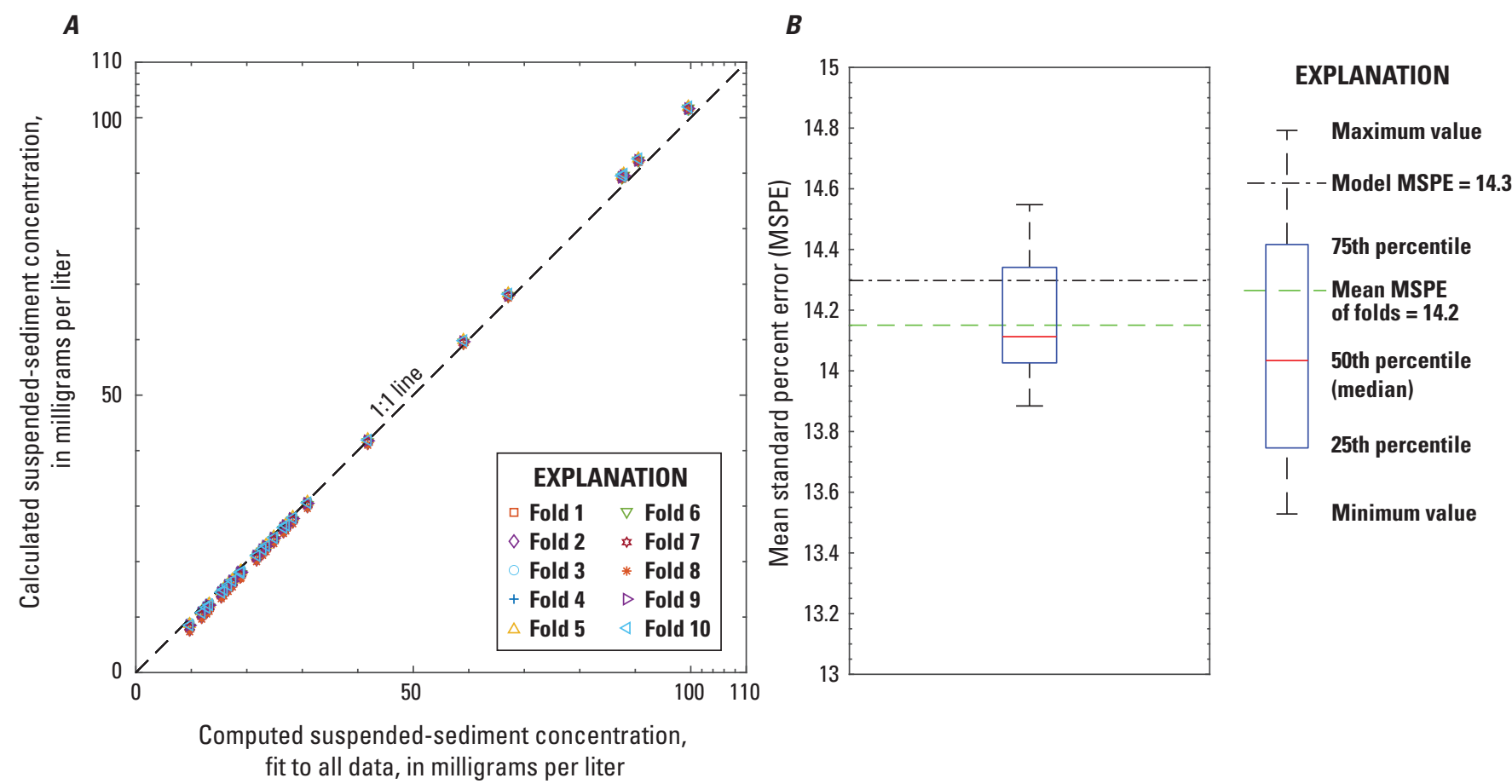

Figure 1.12. Cross-validation of model using varying subsets of for data from station 11455780, Suisun Bay at Benicia Bridge, Calif., at an elevation of 2.4 meters below mean lower low water ("upper"): $A$, calculated suspended-sediment concentration (SSC) from cross-validation by model data subsets compared to SSC computed from model fit to all data; $B$, distribution of cross-validation subset mean standard percent error (MSPE) compared to MSPE of model fit to all data. Data from January 2015 to September 2017 were used. 
Table 1.14. Basic regression statistics for data from January 2015 to September 2017 at station 11455780, Suisun Bay at Benicia Bridge, Calif., elevation of 2.4 meters below mean lower low water ("upper").

\begin{tabular}{lc}
\hline \multicolumn{1}{c}{ Number of observations } & $\mathbf{2 5}$ \\
\hline Standard error (RMSE) & 5.09 \\
Model standard percentage error (MSPE) & 14.3 \\
Coefficient of determination (R²) & 0.97 \\
Adjusted R2 (Adj. R2) & 0.97 \\
\hline
\end{tabular}

Table 1.15. Explanatory variables, coefficients, and statistics for selected regression model for data from January 2015 to September 2017 at station 11455780, Suisun Bay at Benicia Bridge, Calif., at an elevation of 2.4 meters below mean lower low water ("upper").

\begin{tabular}{lcccl}
\hline Variable & Coefficient & $\begin{array}{c}\text { Standard } \\
\text { error }\end{array}$ & t-value & p-value \\
\hline Intercept & 1.89 & 1.60 & 1.18 & 0.25 \\
Turbidity & 1.55 & 0.06 & 27.3 & $5.08 \mathrm{E}-19$ \\
\hline
\end{tabular}

Table 1.16. Flagged observation criteria for data from January 2015 to September 2017 at station 11455780, Suisun Bay at Benicia Bridge, Calif., at an elevation of 2.4 meters below mean lower low water ("upper").

[Cook's D, Cook's distance; \pm , plus or minus]

\begin{tabular}{cccc}
\hline Studentized residual & Leverage & Cooks' D & DFFITS \\
\hline \pm 3 & 0.24 & 0.15 & 0.57 \\
\hline
\end{tabular}

Table 1.17. Flagged observations for data from January 2015 to September 2017 at station 11455780, Suisun Bay at Benicia Bridge, Calif., at an elevation of 2.4 meters below mean lower low water ("upper").

[mm/dd/yyy, month/day/year; hh:mm, hour:minute; FNU, formazin nephelometric units; SSC, suspended-sediment concentration; mg/l, milligrams per liter; Cook's D, Cook's distance]

\begin{tabular}{lcccccc}
\hline $\begin{array}{c}\text { Time } \\
\text { (mm/dd/yyyy hh:mm) }\end{array}$ & $\begin{array}{c}\text { Turbidity } \\
\text { (FNU) }\end{array}$ & $\begin{array}{c}\text { SSC } \\
\text { (mg/l) }\end{array}$ & $\begin{array}{c}\text { Studentized } \\
\text { residual }\end{array}$ & Leverage & $\begin{array}{c}\text { Cooks' } \\
\text { D }\end{array}$ & DFFITS \\
\hline $01 / 08 / 201511: 00$ & 28.3 & 31 & -2.07 & 0.04 & 0.08 & -0.42 \\
$03 / 29 / 201612: 15$ & 52.6 & 62 & -3.31 & 0.13 & 0.61 & -1.31 \\
$02 / 08 / 201714: 45$ & 55.4 & 79 & -2.07 & 0.18 & 0.42 & -0.98 \\
$06 / 28 / 201712: 00$ & 62.9 & 102 & 0.55 & 0.25 & 0.05 & 0.32 \\
$07 / 25 / 201712: 45$ & 36.8 & 49 & -2.21 & 0.07 & 0.15 & -0.60 \\
$08 / 22 / 201715: 00$ & 42.0 & 76 & 1.94 & 0.09 & 0.17 & 0.62 \\
\hline
\end{tabular}


Table 1.18. Suspended-sediment concentration model-calibration dataset from January 2015 to September 2017 for station 11455780, Suisun Bay at Benicia Bridge, Calif., at an elevation of 2.4 meters below mean lower low water ("upper").

[mm/dd/yyy, month/day/year; hh:mm, hour:minute; FNU, formazin nephelometric units; SSC, suspended-sediment concentration; mg/l, milligrams per liter; - , no data]

\begin{tabular}{|c|c|c|c|c|c|}
\hline $\begin{array}{c}\text { Time } \\
\text { (mm/dd/yyyy hh:mm) }\end{array}$ & $\begin{array}{l}\text { Turbidity } \\
\text { (FNU) }\end{array}$ & $\begin{array}{c}\text { SSC } \\
(\mathrm{mg} / \mathrm{l})\end{array}$ & $\begin{array}{c}\text { Computed SSC } \\
(\mathrm{mg} / \mathrm{l})\end{array}$ & $\begin{array}{c}\text { Residual } \\
\text { (mg/l) }\end{array}$ & $\begin{array}{c}\text { Censored } \\
\text { value }\end{array}$ \\
\hline 01/08/2015 11:00 & 28.3 & 31 & 45.8 & -14.8 & Outlier \\
\hline 02/26/2015 10:45 & 11.0 & 14 & 19.0 & -4.97 & - \\
\hline 04/09/2015 08:45 & 15.9 & 23 & 26.6 & -3.60 & - \\
\hline $04 / 28 / 201513: 15$ & 7.00 & 10 & 12.8 & -2.76 & - \\
\hline $06 / 11 / 201512: 15$ & 8.70 & 11 & 15.4 & -4.40 & - \\
\hline $07 / 15 / 201515: 45$ & 13.5 & 30 & 22.8 & 7.15 & - \\
\hline 09/15/2015 11:30 & 18.7 & 29 & 30.9 & -1.92 & - \\
\hline 10/07/2015 11:30 & 10.9 & 22 & 18.8 & 3.19 & - \\
\hline 10/29/2015 09:45 & 12.8 & 23 & 21.8 & 1.24 & - \\
\hline 03/03/2016 13:15 & 9.50 & 15 & 16.6 & -1.64 & - \\
\hline 03/29/2016 12:15 & 52.6 & 62 & 83.6 & -21.6 & Outlier \\
\hline 05/23/2016 12:00 & 55.2 & 89 & 87.6 & 1.40 & - \\
\hline 06/16/2016 11:15 & 13.9 & 32 & 23.3 & 8.53 & - \\
\hline 07/13/2016 11:45 & 10.0 & 15 & 17.4 & -2.41 & - \\
\hline 08/16/2016 12:00 & 57.1 & 95 & 90.6 & 4.45 & - \\
\hline 09/07/2016 11:15 & 7.30 & 10 & 13.2 & -3.22 & - \\
\hline $10 / 12 / 201611: 45$ & 5.03 & 9 & 9.70 & -0.70 & - \\
\hline $11 / 02 / 201612: 30$ & 6.43 & 15 & 11.9 & 3.13 & - \\
\hline $11 / 29 / 201613: 45$ & 16.2 & 28 & 27.0 & 0.96 & - \\
\hline 02/08/2017 14:45 & 55.4 & 79 & 87.9 & -8.91 & - \\
\hline 04/06/2017 11:15 & 17.0 & 33 & 28.3 & 4.72 & - \\
\hline 05/23/2017 11:15 & 25.7 & 37 & 41.8 & -4.79 & - \\
\hline $06 / 28 / 201712: 00$ & 62.9 & 102 & 99.6 & 2.44 & - \\
\hline 07/25/2017 12:45 & 36.8 & 49 & 59.0 & -10.0 & - \\
\hline 08/22/2017 15:00 & 42.0 & 76 & 67.1 & 8.90 & - \\
\hline 08/31/2017 09:15 & 14.8 & 23 & 24.9 & -1.87 & - \\
\hline 09/27/2017 14:00 & 9.00 & 21 & 15.9 & 5.14 & - \\
\hline
\end{tabular}

Date model was created: May 22, 2018

Model application date: October 1, 2016, onward

Analyzed by Daniel Livsey, CAWSC, May 22, 2018

Approved by Maureen Downing-Kunz, CAWSC, June 4, 2018 


\section{Model Summary for Suspended-Sediment Concentration at Station 11455780, Suisun Bay at Benicia Bridge, Calif., Elevation of 18.6 Meters Below Mean Lower Low Water ("Lower")}

The regression model is based on 30 paired measurements of suspended-sediment concentration against concurrent turbidity samples collected from January 8, 2015, through September 30, 2017. Values outside of regression diagnostic criteria ranges (table 1.22) were flagged (table 1.23) and investigated as potential outliers.

The final regression analysis to estimate suspended-sediment concentration at site number 11455780 "lower" resulted in the following model:

$$
S S C=2.73 \times T U R B^{0.857}
$$

The data and analyses used to develop the suspended-sediment concentration model for this site are summarized in tables and figures in this section (tables 1.19 to 1.24 ; figs. 1.13 to 1.16 ).

Table 1.19. Previous and current suspended-sediment concentration model for station 11455780, Suisun Bay at Benicia Bridge, Calif, at an elevation of 18.6 meters below mean lower low water ("lower"). Model coefficient computed as 10 raised to the intercept multiplied by the bias correction factor.

[SSC: suspended-sediment concentration in milligrams per liter (80154); TURB: turbidity in formazin nephelometric units (63680)]

\begin{tabular}{cll}
\hline Start date & \multicolumn{1}{c}{ End date } & \multicolumn{1}{c}{ Model } \\
\hline Oct. 01, 2015 & Sept. 30, 2016 & $\mathrm{SSC}=3.35 \times \mathrm{TURB}^{0.795}$ \\
Oct. 01, 2016 & Ongoing & $\mathrm{SSC}=2.73 \times \mathrm{TURB}^{0.857}$ \\
\hline
\end{tabular}
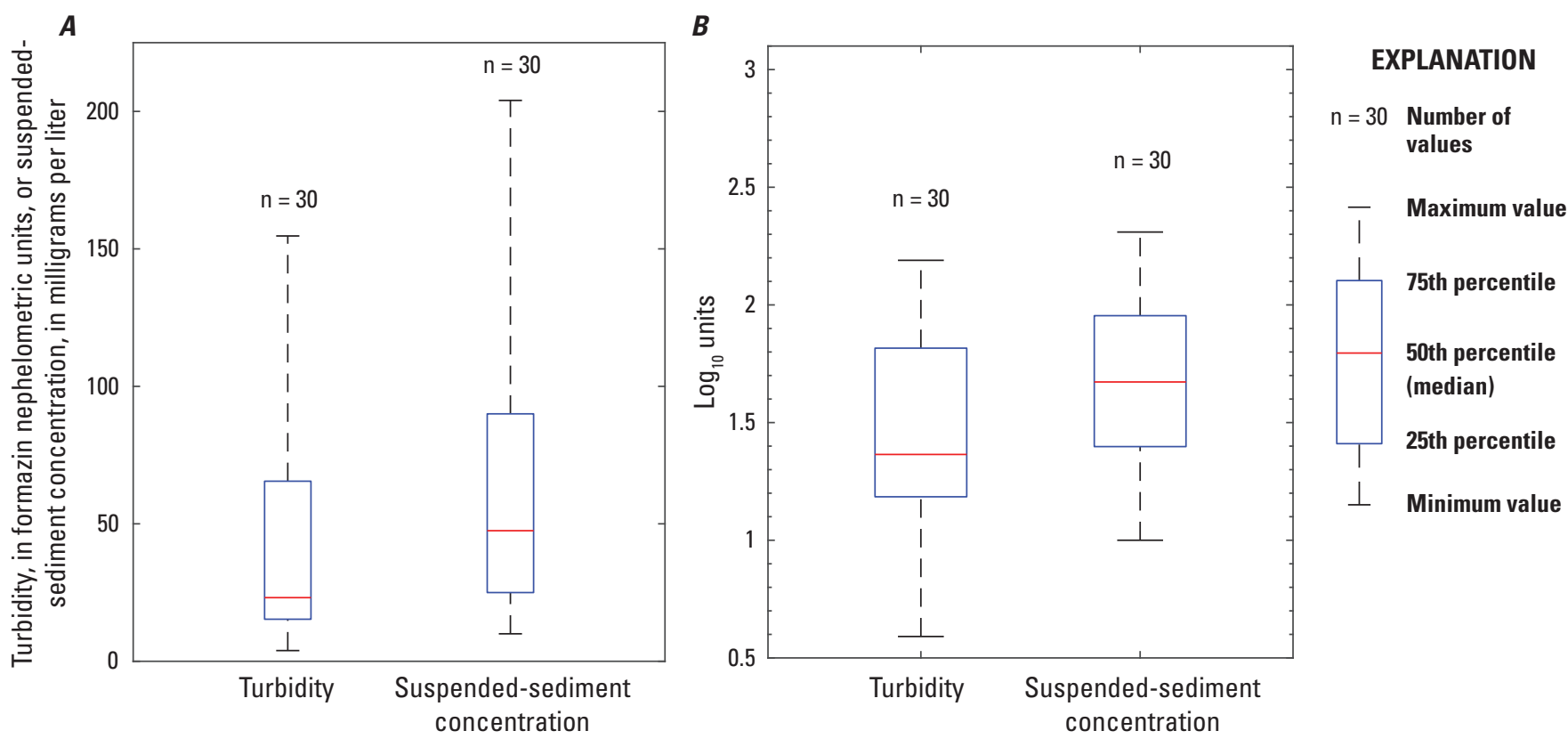

Figure 1.13. Distribution of model variable values for data from station 11455780, Suisun Bay at Benicia Bridge, Calif, at an elevation of 18.6 meters below mean lower low water ("lower") in $A$, linear units, and $B$, log-transformed units. Data from January 2015 to September 2017 were used. 
A
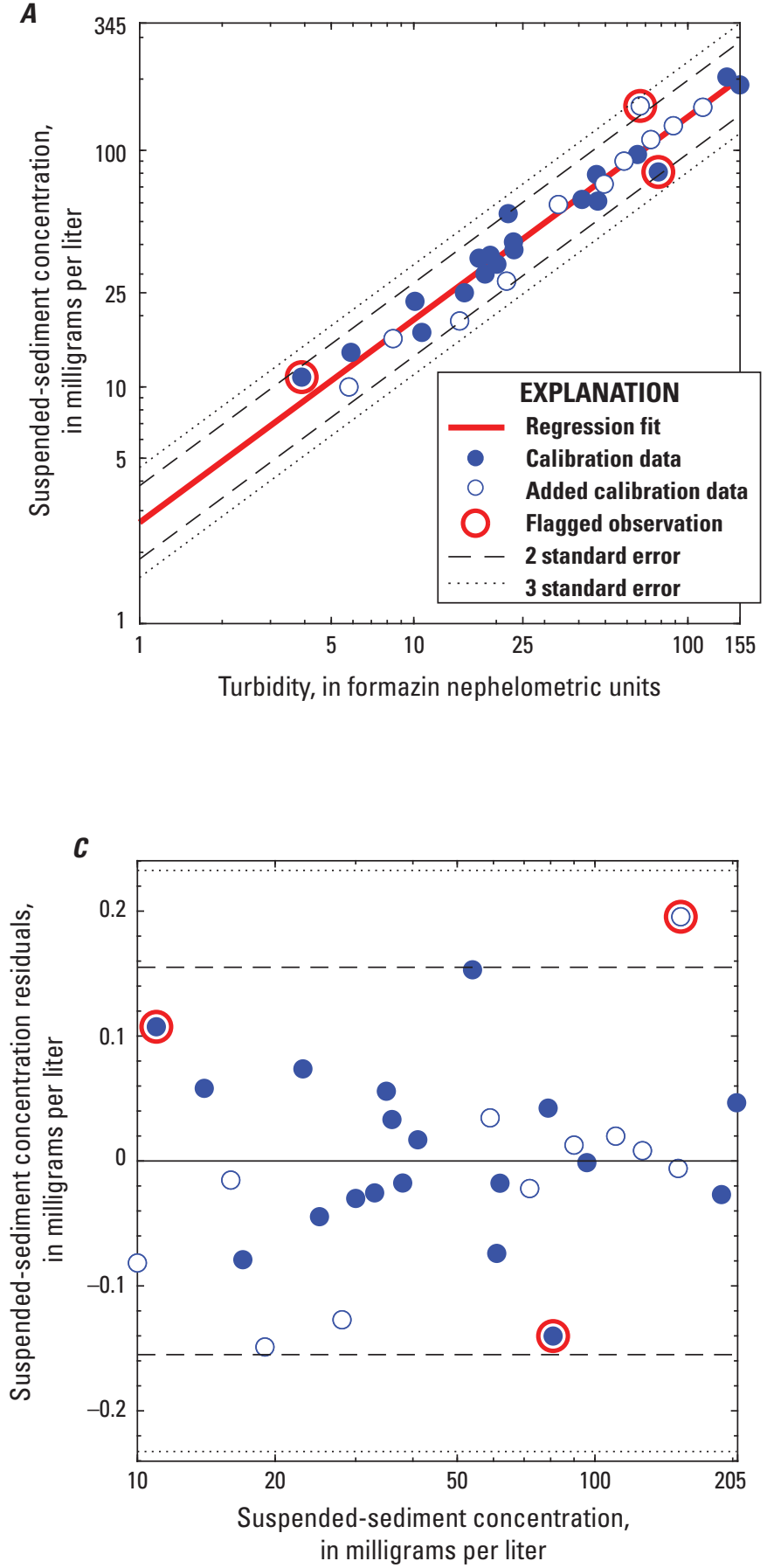
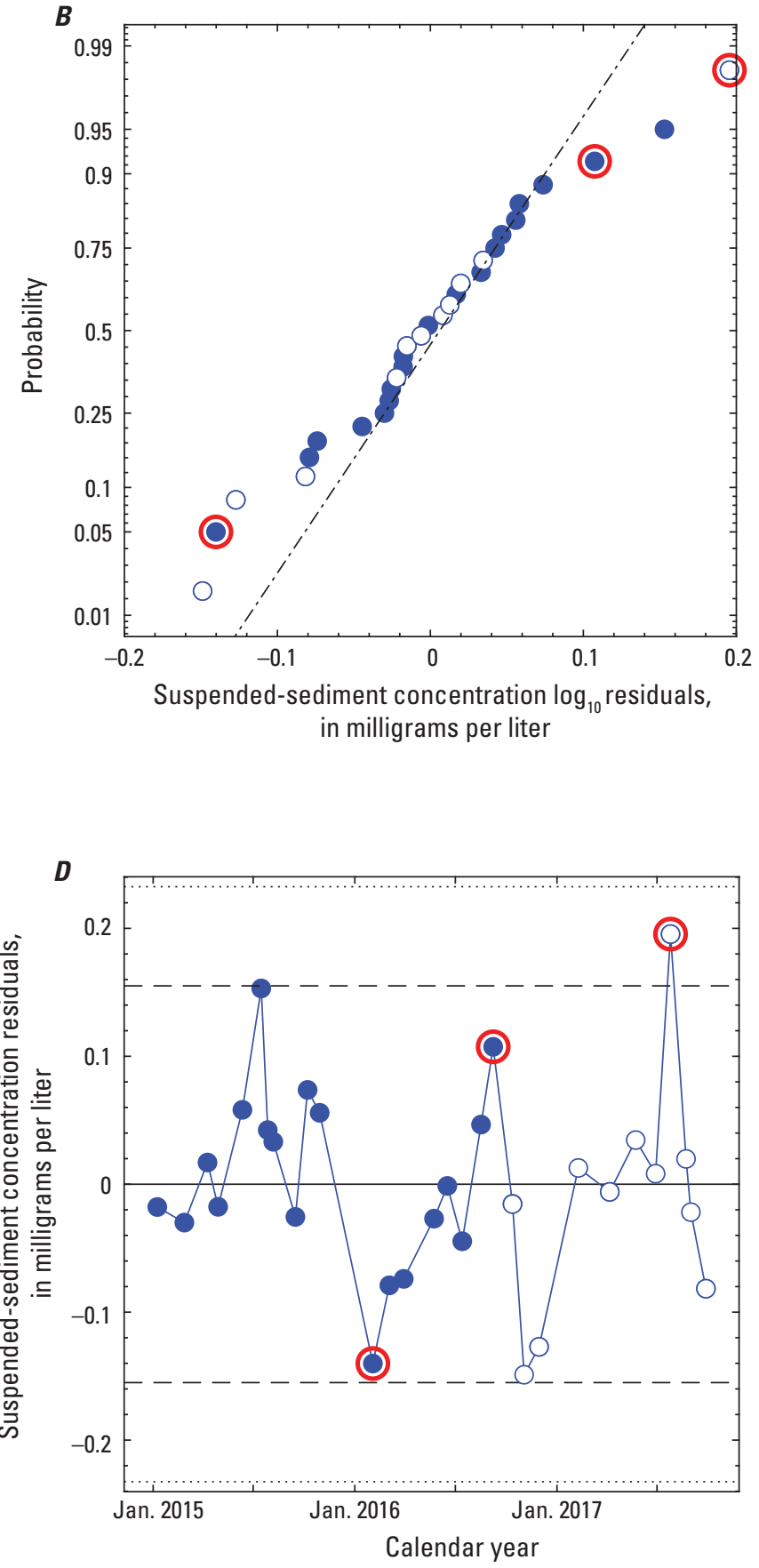

Figure 1.14. Assessment and analyses of model data for station 11455780, Suisun Bay at Benicia Bridge, Calif, at an elevation of 18.6 meters below mean lower low water (“lower"): $A$, model calibration data and regression; $B$, normal quantile plot of model residuals; $C$, model residuals plotted against suspended-sediment concentration (SSC); and $D$, model residual time series. Data from January 2015 to September 2017 were used. 


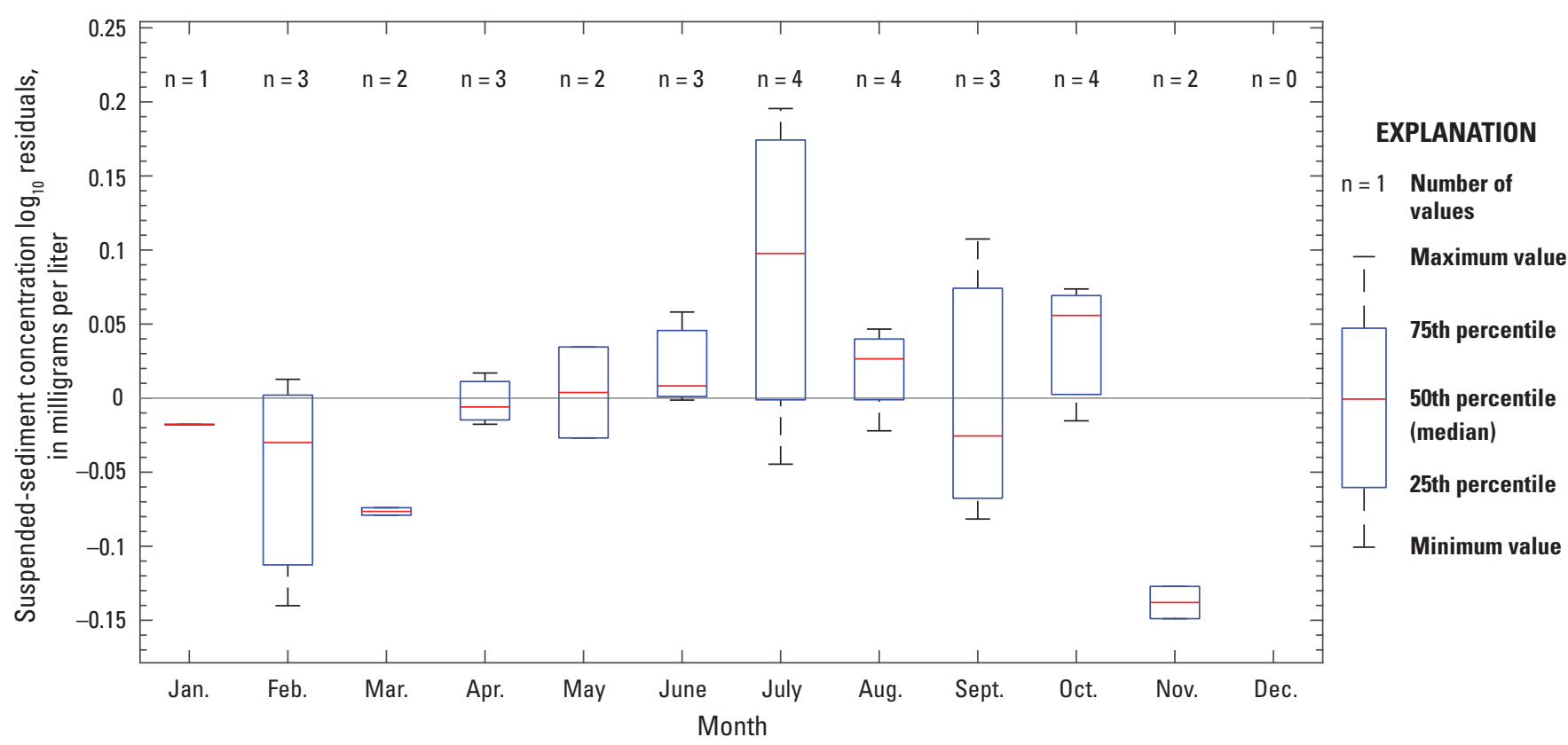

Figure 1.15. Distribution of model residuals by month for station 11455780, Suisun Bay at Benicia Bridge, Calif, at an elevation of 18.6 meters below mean lower low water ("lower"). Data from January 2015 to September 2017 were used.
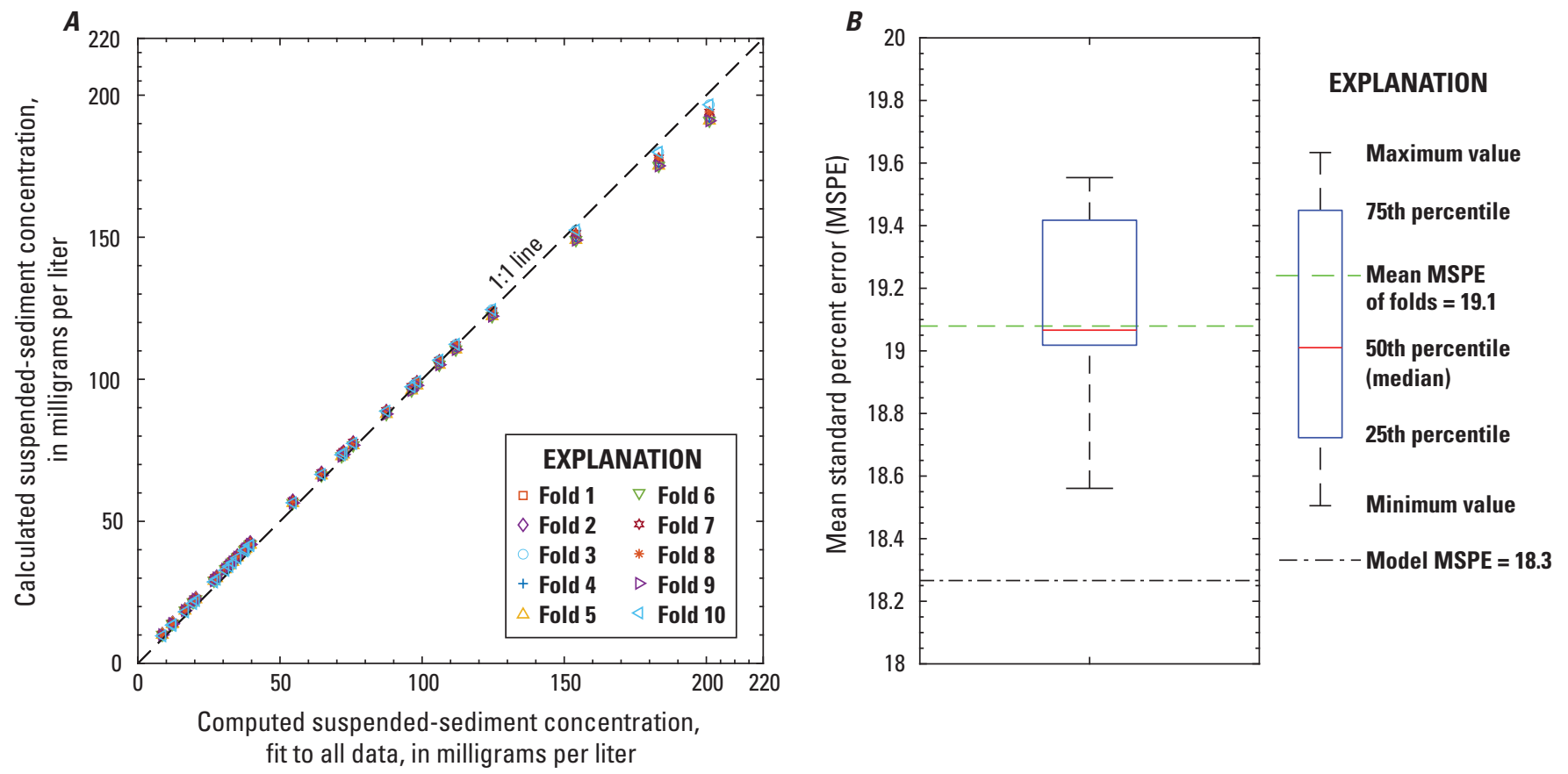

Figure 1.16. Cross-validation of model using varying subsets of for data from station 11455780, Suisun Bay at Benicia Bridge, Calif, at an elevation of 18.6 meters below mean lower low water ("lower"): $A$, calculated suspended-sediment concentration (SSC) from cross-validation by model data subsets compared to SSC computed from model fit to all data; $B$, distribution of cross-validation subset mean standard percent error (MSPE) compared to MSPE of model fit to all data. Data from January 2015 to September 2017 were used. 


\section{A Summary of Water-Quality Monitoring in San Francisco Bay in Water Year 2017}

Table 1.20. Basic regression statistics for data from January 2015 to September 2017 at station 11455780, Suisun Bay at Benicia Bridge, Calif, at an elevation of 18.6 meters below mean lower low water ("lower").

\begin{tabular}{lc}
\hline \multicolumn{1}{c}{ Number of observations } & $\mathbf{3 0}$ \\
\hline Standard error (RMSE) & 0.08 \\
Model standard percentage error (MSPE) & 18.3 \\
Coefficient of determination ( $\left.{ }^{2}\right)$ & 0.96 \\
Adjusted $\mathrm{R}^{2}$ (Adj. $\mathrm{R}^{2}$ ) & 0.96 \\
\hline
\end{tabular}

Table 1.22. Flagged observation criteria for data from January 2015 to September 2017 at station 11455780, Suisun Bay at Benicia Bridge, Calif, at an elevation of 18.6 meters below mean lower low water ("lower").

[Cook's D, Cook's distance; \pm , plus or minus]

\begin{tabular}{cccc}
\hline Studentized residual & Leverage & Cooks' D & DFFITS \\
\hline \pm 3 & 0.20 & 0.11 & 0.52 \\
\hline
\end{tabular}

Table 1.21. Explanatory variables, coefficients, and statistics for selected regression model for data from January 2015 to September 2017 at station 11455780, Suisun Bay at Benicia Bridge, Calif, at an elevation of 18.6 meters below mean lower low water ("lower").

\begin{tabular}{lcccc}
\hline \multicolumn{1}{c}{ Variable } & Coefficient & $\begin{array}{c}\text { Standard } \\
\text { error }\end{array}$ & t-value & p-value \\
\hline Intercept & 0.428 & 0.05 & 8.18 & $6.56 \mathrm{E}-09$ \\
Slope & 0.857 & 0.03 & 24.8 & $1.35 \mathrm{E}-20$ \\
Bias correction & 1.02 & - & - & - \\
$\quad$ factor (BCF) & & & & \\
\hline
\end{tabular}

Table 1.23. Flagged observations for data from January 2015 to September 2017 at station 11455780, Suisun Bay at Benicia Bridge, Calif, at an elevation of 18.6 meters below mean lower low water ("lower").

[mm/dd/yyy, month/day/year; hh:mm, hour:minute; FNU, formazin nephelometric units; SSC, suspended-sediment concentration; mg/l, milligrams per liter; Cook's D, Cook's distance]

\begin{tabular}{lcccccc}
\hline $\begin{array}{c}\text { Time } \\
\text { (mm/dd/yyyy hh:mm) }\end{array}$ & $\begin{array}{c}\text { Turbidity } \\
\text { (FNU) }\end{array}$ & $\begin{array}{c}\text { SSC } \\
\text { (mg/l) }\end{array}$ & $\begin{array}{c}\text { Studentized } \\
\text { residual }\end{array}$ & Leverage & $\begin{array}{c}\text { Cooks' } \\
\text { D }\end{array}$ & DFFITS \\
\hline 02/02/2016 16:00 & 78.0 & 81 & -1.93 & 0.07 & 0.13 & -0.53 \\
09/07/2016 11:00 & 3.90 & 11 & 1.54 & 0.18 & 0.24 & 0.71 \\
07/25/2017 13:00 & 67.0 & 154 & 2.87 & 0.06 & 0.21 & 0.72 \\
\hline
\end{tabular}


Table 1.24. Suspended-sediment concentration model-calibration dataset for data from January 2015 to September 2017 at station 11455780, Suisun Bay at Benicia Bridge, Calif, at an elevation of 18.6 meters below mean lower low water ("lower").

$[\mathrm{mm} / \mathrm{dd} / \mathrm{yyy}$, month/day/year; hh:mm, hour:minute; FNU, formazin nephelometric units; SSC, suspended-sediment concentration; mg/l, milligrams per liter; - , no data]

\begin{tabular}{|c|c|c|c|c|c|}
\hline $\begin{array}{c}\text { Time } \\
\text { (mm/dd/yyyy hh:mm) }\end{array}$ & $\begin{array}{l}\text { Turbidity } \\
\text { (FNU) }\end{array}$ & $\begin{array}{l}\text { SSC } \\
(\mathrm{mg} / \mathrm{l})\end{array}$ & $\begin{array}{c}\text { Computed SSC } \\
(\mathrm{mg} / \mathrm{l})\end{array}$ & $\begin{array}{c}\text { Residual } \\
\text { (mg/l) }\end{array}$ & $\begin{array}{c}\text { Censored } \\
\text { value }\end{array}$ \\
\hline 01/08/2015 11:15 & 41.1 & 62 & 66.0 & -4.02 & - \\
\hline 02/26/2015 10:30 & 18.2 & 30 & 32.8 & -2.85 & - \\
\hline 04/09/2015 09:00 & 23.1 & 41 & 40.3 & 0.71 & - \\
\hline 04/28/2015 13:00 & 23.2 & 38 & 40.4 & -2.44 & - \\
\hline 06/11/2015 12:30 & 5.90 & 14 & 12.5 & 1.49 & - \\
\hline 07/15/2015 15:30 & 22.1 & 54 & 38.8 & 15.2 & - \\
\hline 07/27/2015 10:15 & 46.4 & 79 & 73.2 & 5.75 & - \\
\hline 08/06/2015 10:30 & 19.0 & 36 & 34.1 & 1.92 & - \\
\hline 09/15/2015 11:15 & 20.1 & 33 & 35.8 & -2.76 & - \\
\hline 10/07/2015 11:45 & 10.1 & 23 & 19.8 & 3.17 & - \\
\hline 10/29/2015 09:30 & 17.3 & 35 & 31.4 & 3.55 & - \\
\hline 02/02/2016 16:00 & 78 & 81 & 114 & -33.3 & - \\
\hline 03/03/2016 13:30 & 10.7 & 17 & 20.8 & -3.83 & - \\
\hline 03/29/2016 12:30 & 46.9 & 61 & 73.9 & -12.9 & - \\
\hline 05/23/2016 11:45 & 155 & 189 & 206 & -16.9 & - \\
\hline 06/16/2016 11:00 & 65.5 & 96 & 98.4 & -2.43 & - \\
\hline 07/13/2016 11:30 & 15.3 & 25 & 28.3 & -3.31 & - \\
\hline 08/16/2016 11:45 & 139 & 204 & 188 & 16.4 & - \\
\hline 09/07/2016 11:00 & 3.90 & 11 & 8.77 & 2.23 & - \\
\hline 10/12/2016 11:30 & 8.40 & 16 & 16.9 & -0.93 & - \\
\hline $11 / 02 / 201612: 15$ & 14.7 & 19 & 27.4 & -8.35 & - \\
\hline $11 / 29 / 201613: 30$ & 21.8 & 28 & 38.3 & -10.3 & - \\
\hline 02/08/2017 15:00 & 58.5 & 90 & 89.3 & 0.66 & - \\
\hline 04/06/2017 11:00 & 113 & 152 & 157 & -5.07 & - \\
\hline 05/23/2017 11:00 & 33.7 & 59 & 55.7 & 3.31 & - \\
\hline 06/28/2017 11:45 & 88.5 & 127 & 127 & -0.39 & - \\
\hline 07/25/2017 13:00 & 67.0 & 154 & 100 & 53.6 & - \\
\hline 08/22/2017 14:45 & 73.3 & 111 & 108 & 2.61 & - \\
\hline 08/31/2017 09:00 & 49.5 & 72 & 77.4 & -5.42 & - \\
\hline 09/27/2017 13:45 & 5.80 & 10 & 12.3 & -2.33 & - \\
\hline
\end{tabular}

Date model was created: May 22, 2018

Model application date: October 1, 2016, onward

Analyzed by Daniel Livsey, CAWSC, May 22, 2018

Approved by Maureen Downing-Kunz, CAWSC, June 4, 2018 


\section{San Francisco Bay at Richmond-San Rafael Bridge, Calif., Station 375607122264701; Two Sensor Elevations}

Location: San Francisco Bay at Richmond-San Rafael Bridge, site number 375607122264701, latitude 3756'07' longitude $122^{\circ} 26^{\prime} 47^{\prime \prime}$ referenced to North American Datum of 1983, Marin County, Calif., Hydrologic Unit 18050002, unsurveyed, at north side of the bridge pier at milepost 6.22, directly under the Richmond-San Rafael Bridge (Interstate 580), east side of ship navigation channel. Equipment is housed in a 0.4-by- $0.4 \mathrm{~m}$ environmental shelter attached to an interior railing on the north side of the bridge pier. The station is accessed by boat. Tides are semidiurnal, range about $1.8 \mathrm{~m}$, and follow a 14-day spring-neap cycle. Tidal currents reverse direction twice a day, and maximum speeds range from $0.2 \mathrm{~m} / \mathrm{s}$ in shallow water to more than $1 \mathrm{~m} / \mathrm{s}$ in deep channels. Mean lower low water (MLLW) depth is about $13.7 \mathrm{~m}$.

Equipment: YSI 6920 multi-parameter water-quality sondes equipped with specific conductance and temperature probe (YSI model 6560), turbidity (YSI model 6136), and pressure sensor for water depth above instrument (not tied in to a reference elevation and not published) are deployed at two depths: mid-depth (4.6 m below MLLW) and near-bottom (12.2 $\mathrm{m}$ below MLLW at $1.5 \mathrm{~m}$ above bottom). Parameters are measured every 15 minutes; value reported is the average of a 12 -second burst with a sampling rate of $2 \mathrm{~Hz}$. The sensors are suspended in the water column using synthetic deployment line attached to a stainless-steel cable suspended vertically from a galvanized metal davit mounted on the pier and attached to a 91-kg weight resting on the bed. Each sonde is equipped with a communication cable that connects to a datalogger (CR10X from Campbell Scientific) connected to cellular modem that allows for telemetry of data.

Water samples for SSC analysis are collected using a point sampler at the same elevation as the turbidity sensor. Cross-section surveys are not conducted at this site because of the large horizontal and vertical variability in cross-section SSC.

\section{Model Summary for Suspended-Sediment Concentration at Station 375607122264701 San Francisco Bay at Richmond-San Rafael Bridge, Calif., Elevation of 4.6 Meters Below Mean Lower Low Water ("Upper")}

The regression model is based on 20 paired measurements of suspended-sediment concentration against concurrent turbidity samples collected from January 7, 2015, through September 30, 2017. Values outside of regression diagnostic criteria ranges (table 1.28) were flagged (table 1.29) and investigated as potential outliers. The greatest positive residuals were from data collected July to October 2015; field notes during this period indicate large particles or clear water in samples, indicating an increase in the ratio of SSC to turbidity, reflected by the large positive residuals during this time, was possibly induced by an increase in suspended particle size.

The final regression analysis to estimate suspended-sediment concentration at site number 375607122264701 "upper" resulted in the following model:

$$
S S C=4.12 \times T U R B^{0.753}
$$

The data and analyses used to develop the suspended-sediment concentration model for this site are summarized in tables and figures in this section (tables 1.25 to 1.30 ; figs. 1.17 to 1.20 ). 
Table 1.25. Previous and current suspended-sediment concentration model for station 375607122264701, San Francisco

Bay at Richmond-San Rafael Bridge, Calif., at an elevation of 4.6 meters below mean lower low water ("upper"). Model coefficient computed as 10 raised to the intercept multiplied by the bias correction factor.

[SSC: suspended-sediment concentration in milligrams per liter (80154); TURB: turbidity in formazin nephelometric units (63680)]

\begin{tabular}{cll}
\hline Start date & \multicolumn{1}{c}{ End date } & \multicolumn{1}{c}{ Model } \\
\hline Oct. 01, 2015 & Sept. 30, 2016 & $\mathrm{SSC}=3.16 \times \mathrm{TURB}+8.38$ \\
Oct. 01, 2016 & Ongoing & $\mathrm{SSC}=4.12 \times \mathrm{TURB}^{0.753}$ \\
\hline
\end{tabular}
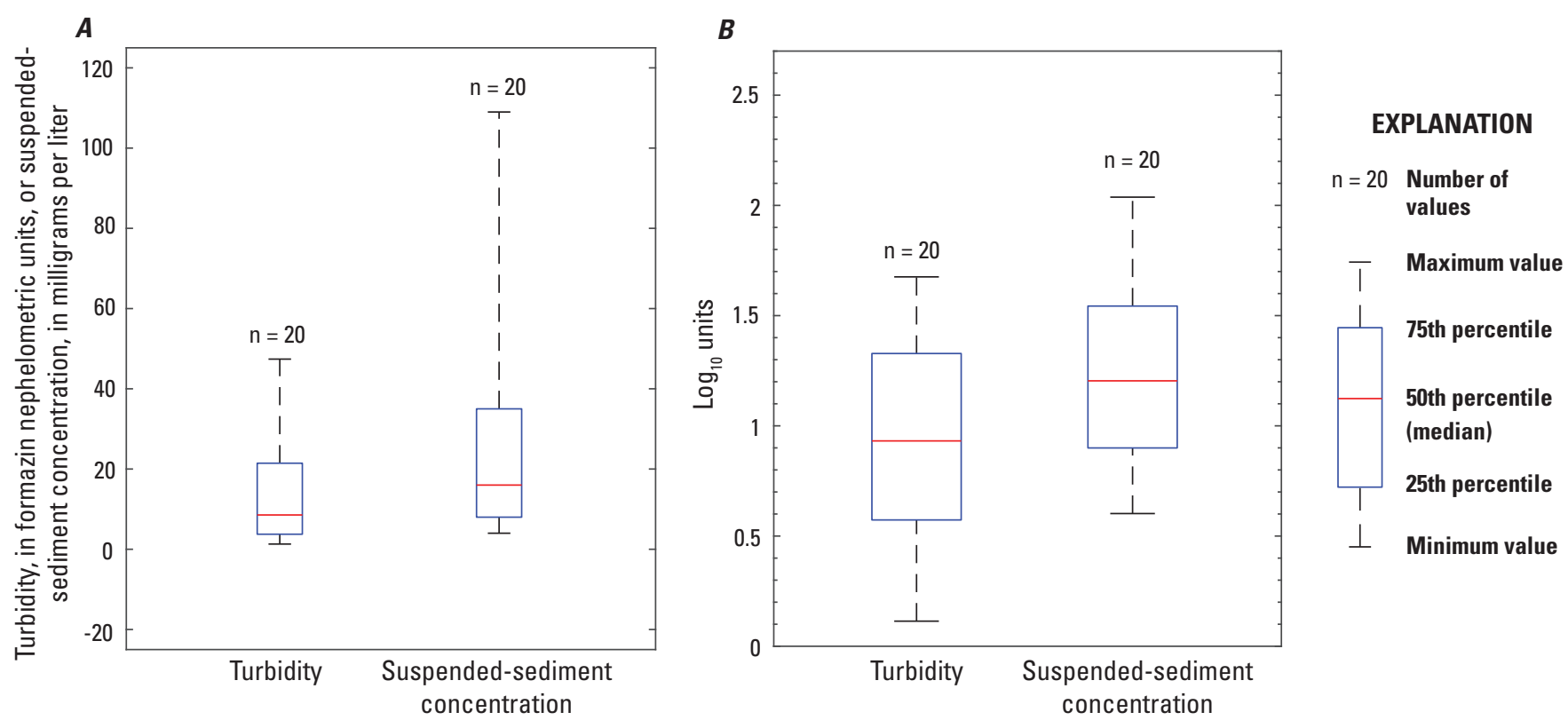

Figure 1.17. Distribution of model variable values for data from station 375607122264701 , San Francisco Bay at Richmond-San Rafael Bridge, Calif., at an elevation of 4.6 meters below mean lower low water ("upper") in $A$, linear units, and $B$, log-transformed units. Data from January 2015 to September 2017 were used. 
$\boldsymbol{A}$

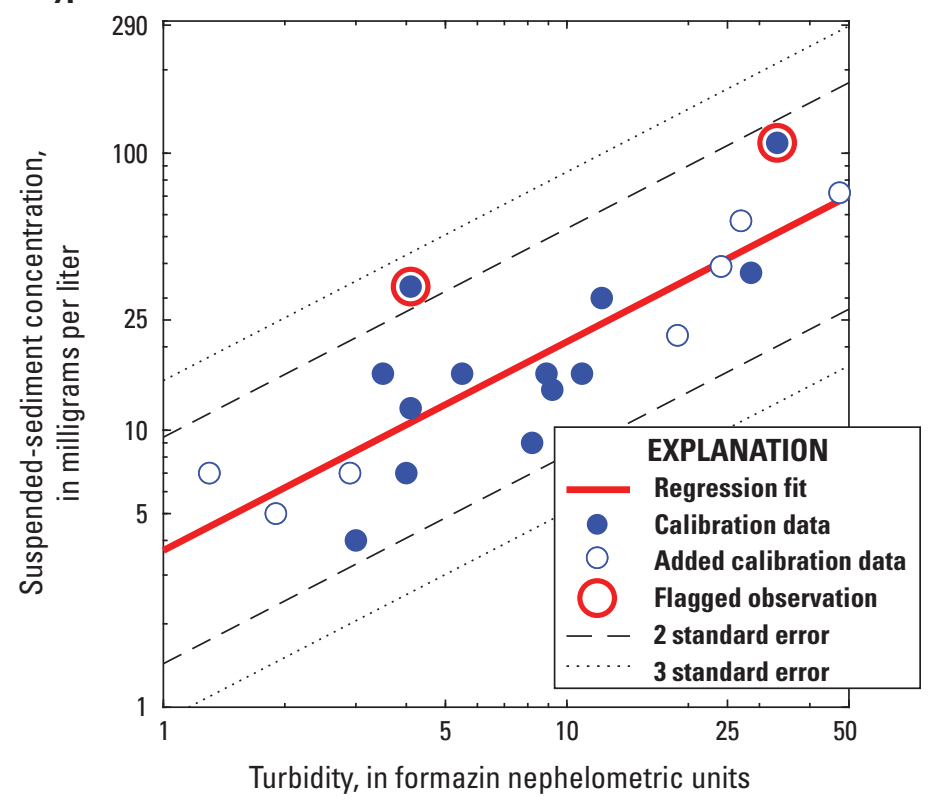

B

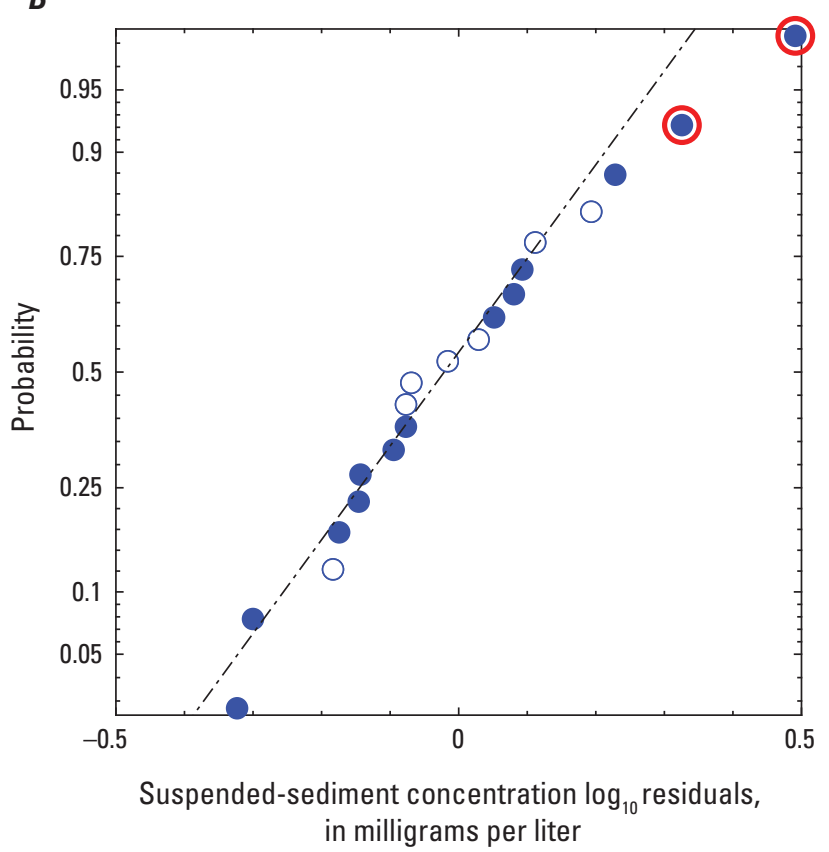

D

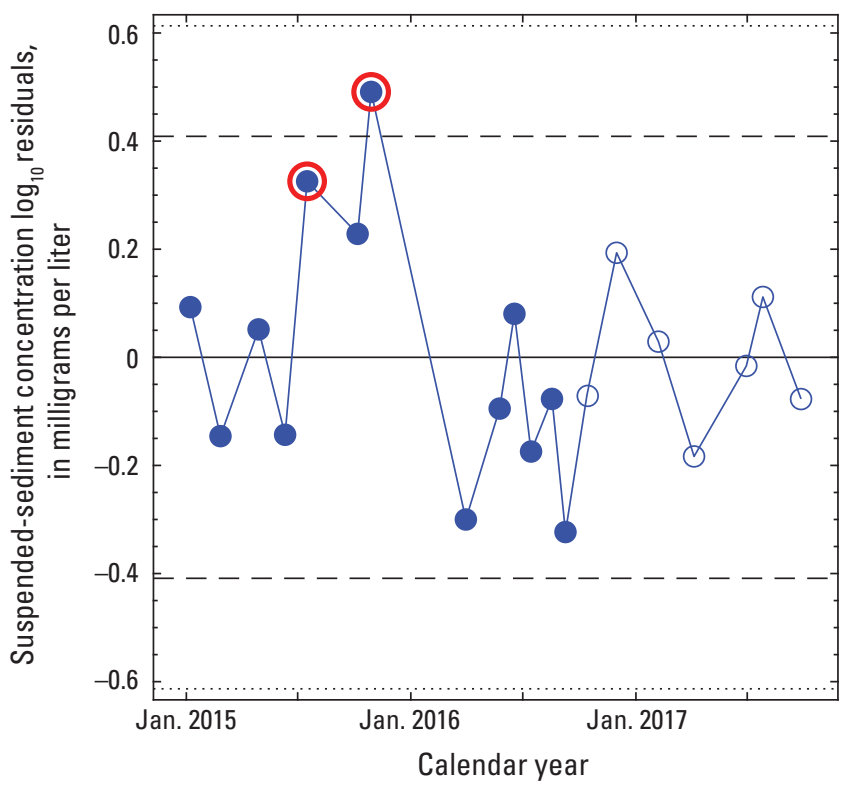

Figure 1.18. Assessment and analyses of model data for station 375607122264701, San Francisco Bay at Richmond-San Rafael Bridge, Calif., at an elevation of 4.6 meters below mean lower low water ("upper"): $A$, model calibration data and regression; $B$, normal quantile plot of model residuals; $C$, model residuals plotted against suspended-sediment concentration (SSC); and $D$, model residual time series. Data from January 2015 to September 2017 were used. 


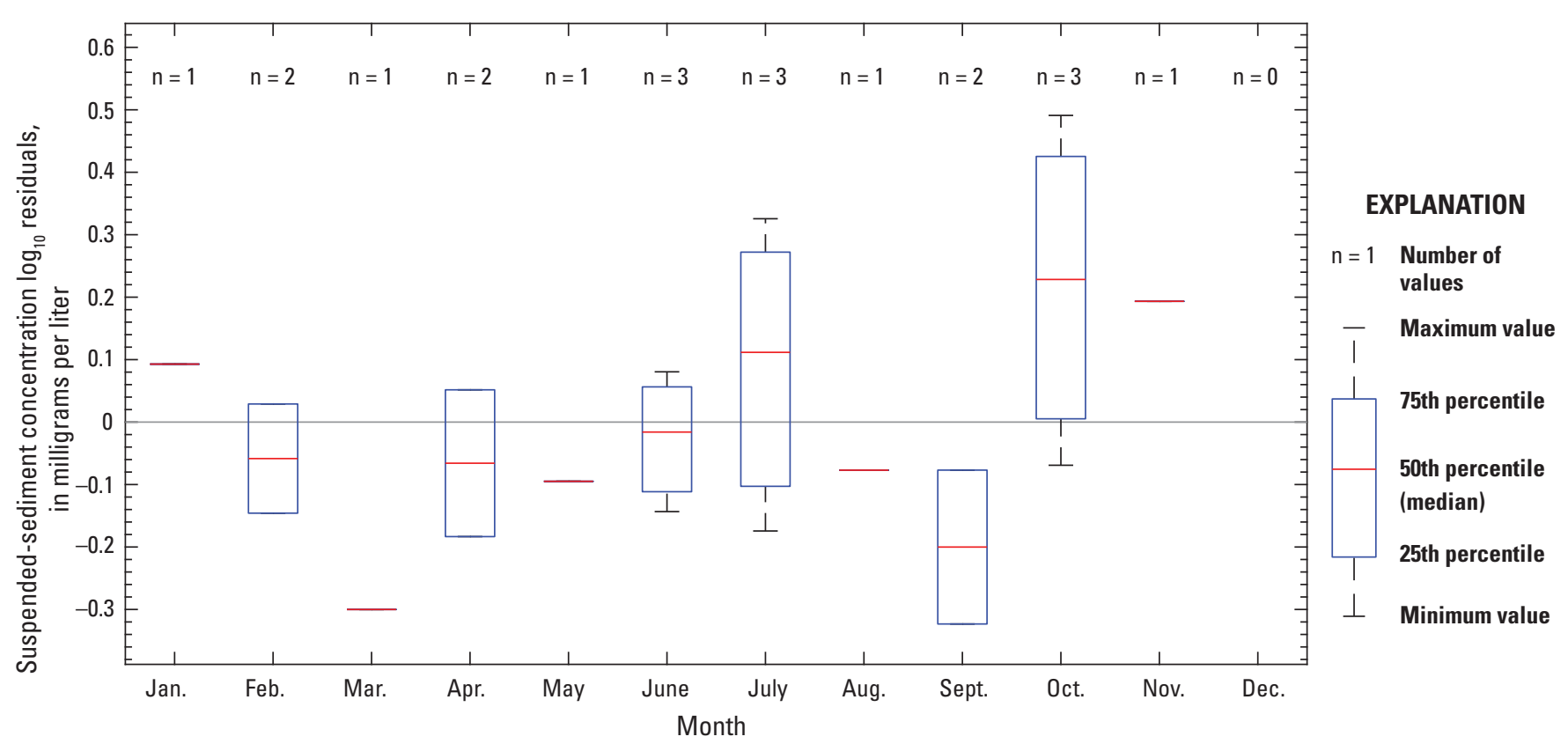

Figure 1.19. Distribution of model residuals by month for station 375607122264701, San Francisco Bay at Richmond-San Rafael Bridge, Calif., at an elevation of 4.6 meters below mean lower low water ("upper"). Data from January 2015 to September 2017 were used.
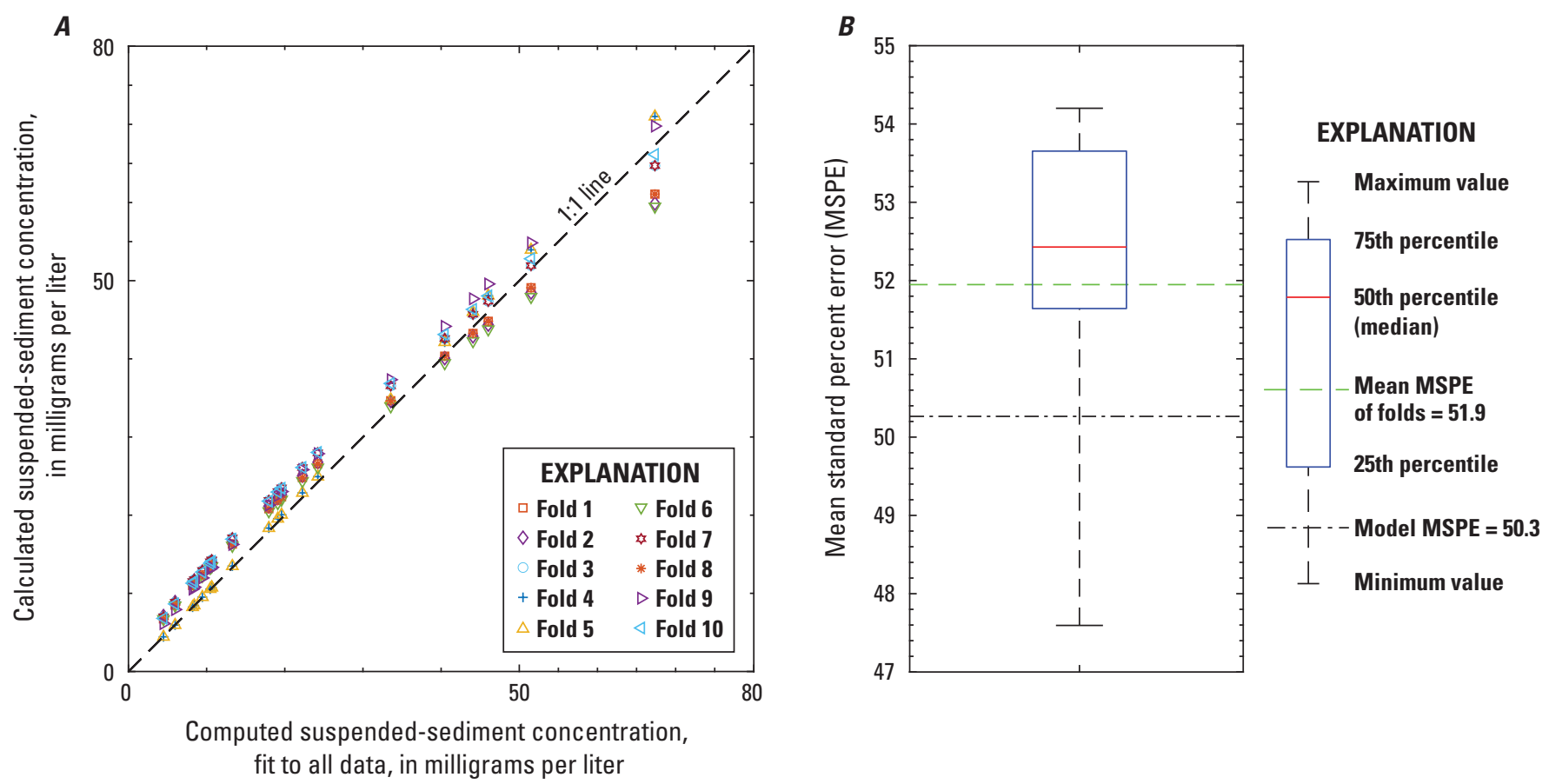

Figure 1.20. Cross-validation of model using varying subsets of for data from station 375607122264701, San Francisco Bay at Richmond-San Rafael Bridge, Calif., at an elevation of 4.6 meters below mean lower low water ("upper"): $A$, calculated suspended-sediment concentration (SSC) from cross-validation by model data subsets compared to SSC computed from model fit to all data; $B$, distribution of cross-validation subset mean standard percent error (MSPE) compared to MSPE of model fit to all data. Data from January 2015 to September 2017 were used. 
Table 1.26. Basic regression statistics for data from January 2015 to September 2017 at station 375607122264701 , San Francisco Bay at Richmond-San Rafael Bridge, Calif., at an elevation of 4.6 meters below mean lower low water ("upper").

\begin{tabular}{lc}
\hline \multicolumn{1}{c}{ Number of observations } & $\mathbf{2 0}$ \\
\hline Standard error (RMSE) & 0.21 \\
Model standard percentage error (MSPE) & 50.3 \\
Coefficient of determination ( $\left.{ }^{2}\right)$ & 0.73 \\
Adjusted $\mathrm{R}^{2}$ (Adj. $\mathrm{R}^{2}$ ) & 0.72 \\
\hline
\end{tabular}

Table 1.28. Flagged observation criteria for data from January 2015 to September 2017 at station 375607122264701 , San Francisco Bay at Richmond-San Rafael Bridge, Calif., at an elevation of 4.6 meters below mean lower low water ("upper").

[Cook's D, Cook's distance; \pm , plus or minus]

\begin{tabular}{cccc}
\hline Studentized residual & Leverage & Cooks' D & DFFITS \\
\hline \pm 3 & 0.30 & 0.16 & 0.63 \\
\hline
\end{tabular}

Table 1.27. Explanatory variables, coefficients, and statistics for selected regression model for station 375607122264701, San Francisco Bay at Richmond-San Rafael Bridge, Calif., at an elevation of 4.6 meters below mean lower low water ("upper").

$[-$, no data $]$

\begin{tabular}{lcccc}
\hline \multicolumn{1}{c}{ Variable } & Coefficient & $\begin{array}{c}\text { Standard } \\
\text { error }\end{array}$ & t-value & p-value \\
\hline Intercept & 0.566 & 0.11 & 5.22 & $5.84 \mathrm{E}-05$ \\
Slope & 0.753 & 0.11 & 6.98 & $1.60 \mathrm{E}-06$ \\
$\begin{array}{l}\text { Bias correction } \\
\text { factor (BCF) }\end{array}$ & 1.12 & - & - & - \\
\hline
\end{tabular}

Table 1.29. Flagged observations for data from January 2015 to September 2017 at station 375607122264701, San Francisco Bay at Richmond-San Rafael Bridge, Calif., at an elevation of 4.6 meters below mean lower low water ("upper").

[mm/dd/yyy, month/day/year; hh:mm, hour:minute; FNU, formazin nephelometric units; SSC, suspended-sediment concentration; mg/l, milligrams per liter; Cook's D, Cook's distance]

\begin{tabular}{lcccccc}
\hline $\begin{array}{c}\text { Time } \\
\text { (mm/dd/yyyy hh:mm) }\end{array}$ & $\begin{array}{c}\text { Turbidity } \\
\text { (FNU) }\end{array}$ & $\begin{array}{c}\text { SSC } \\
\text { (mg/l) }\end{array}$ & $\begin{array}{c}\text { Studentized } \\
\text { residual }\end{array}$ & Leverage & $\begin{array}{c}\text { Cooks' } \\
\text { D }\end{array}$ & DFFITS \\
\hline 07/16/2015 10:00 & 33.2 & 109 & 1.78 & 0.15 & 0.25 & 0.75 \\
10/28/2015 12:00 & 4.10 & 33 & 2.88 & 0.07 & 0.23 & 0.81 \\
\hline
\end{tabular}


Table 1.30. Suspended-sediment concentration model-calibration dataset for data from January 2015 to September 2017 at station 375607122264701, San Francisco Bay at Richmond-San Rafael Bridge, Calif., at an elevation of 4.6 meters below mean lower low water ("upper").

$[\mathrm{mm} / \mathrm{dd} / \mathrm{yyy}$, month/day/year; hh:mm, hour:minute; FNU, formazin nephelometric units; $\mathrm{mg} / \mathrm{l}$, milligrams per liter; SSC, suspended-sediment concentration; - , no data]

\begin{tabular}{|c|c|c|c|c|c|}
\hline $\begin{array}{c}\text { Time } \\
\text { (mm/dd/yyyy hh:mm) }\end{array}$ & $\begin{array}{l}\text { Turbidity } \\
\text { (FNU) }\end{array}$ & $\begin{array}{l}\text { SSC } \\
(\mathrm{mg} / \mathrm{l})\end{array}$ & $\begin{array}{c}\text { Computed SSC } \\
(\mathrm{mg} / \mathrm{l})\end{array}$ & $\begin{array}{c}\text { Residual } \\
\text { (mg/l) }\end{array}$ & $\begin{array}{l}\text { Censored } \\
\text { value }\end{array}$ \\
\hline 01/07/2015 12:45 & 12.2 & 30 & 27.1 & 2.88 & - \\
\hline 02/25/2015 12:00 & 9.20 & 14 & 21.9 & -7.93 & - \\
\hline 04/28/2015 10:30 & 4.10 & 12 & 11.9 & 0.07 & - \\
\hline 06/10/2015 14:00 & 10.9 & 16 & 24.9 & -8.91 & - \\
\hline 07/16/2015 10:00 & 33.2 & 109 & 57.6 & 51.4 & - \\
\hline $10 / 06 / 201512: 30$ & 3.50 & 16 & 10.6 & 5.41 & - \\
\hline 10/28/2015 12:00 & 4.10 & 33 & 11.9 & 21.1 & - \\
\hline 03/30/2016 12:00 & 8.20 & 9 & 20.1 & -11.1 & - \\
\hline 05/24/2016 11:15 & 28.6 & 37 & 51.5 & -14.5 & - \\
\hline 06/17/2016 12:00 & 5.50 & 16 & 14.9 & 1.12 & - \\
\hline 07/14/2016 12:00 & 4.00 & 7 & 11.7 & -4.71 & - \\
\hline 08/17/2016 13:15 & 8.90 & 16 & 21.4 & -5.38 & - \\
\hline 09/08/2016 11:30 & 3.00 & 4 & 9.43 & -5.43 & - \\
\hline 10/13/2016 12:00 & 2.90 & 7 & 9.19 & -2.19 & - \\
\hline $11 / 30 / 201614: 45$ & 1.30 & 7 & 5.02 & 1.98 & - \\
\hline 02/06/2017 14:45 & 47.4 & 72 & 75.3 & -3.35 & - \\
\hline 04/05/2017 12:45 & 18.8 & 22 & 37.6 & -15.6 & - \\
\hline 06/29/2017 13:15 & 24.1 & 39 & 45.3 & -6.28 & - \\
\hline 07/26/2017 11:00 & 27.0 & 57 & 49.3 & 7.68 & - \\
\hline 09/26/2017 11:45 & 1.90 & 5 & 6.69 & -1.69 & - \\
\hline
\end{tabular}

Date model was created: November 26, 2018

Model application date: October 1, 2016, onward

Analyzed by Daniel Livsey, CAWSC, November 26, 2018

Approved by Maureen Downing-Kunz, CAWSC, November 26, 2018 


\section{Model Summary for Suspended-Sediment Concentration at Station 375607122264701 San Francisco Bay at Richmond-San Rafael Bridge, Calif., Elevation of 13.7 Meters Below Mean Lower Low Water ("Lower")}

The regression model is based on 19 paired measurements of suspended-sediment concentration against conconsurrent turbidity samples collected from January 7, 2015, through September 30,2017. Values outside of regression diagnostic criteria ranges (table 1.34) were flagged (table 1.35) and investigated as potential outliers. The sample from April 5, 2017, was excluded from the model dataset because the water-quality sonde was not deployed at the proper depth when then the SSC sample was collected. Largest positive residuals were measured from July to October 2015; field notes during this period indicate large particles or clear water in samples, indicating an increase in the ratio of SSC to turbidity, reflected by the large positive residuals during this time, was possibly induced by an increase in suspended particle size.

The final regression analysis to estimate suspended-sediment concentration at site number 375607122264701 "lower" resulted in the following model:

$$
S S C=5.25 \times T U R B^{0.744}
$$

The data and analyses used to develop the suspended-sediment concentration model for this site are summarized in tables and figures in this section (tables 1.31 to 1.36 ; figs. 1.21 to 1.24 ).

Table 1.31. Previous and current suspended-sediment concentration model for station 375607122264701 , San Francisco

Bay at Richmond-San Rafael Bridge, Calif., at an elevation of 13.7 meters below mean lower low water ("lower"). Model coefficient computed as 10 raised to the intercept multiplied by the bias correction factor.

[SSC: suspended-sediment concentration in milligrams per liter (80154); TURB: turbidity in formazin nephelometric units (63680)]

\begin{tabular}{cll}
\hline \multicolumn{1}{c}{ Start date } & \multicolumn{1}{c}{ End date } & \multicolumn{1}{c}{ Model } \\
\hline Oct. 01,2015 & Sept. 30,2016 & $\mathrm{SSC}=2.45 \times$ TURB +15.4 \\
Oct. 01,2016 & Ongoing & $\mathrm{SSC}=5.25 \times$ TURB 0.744 \\
\hline
\end{tabular}
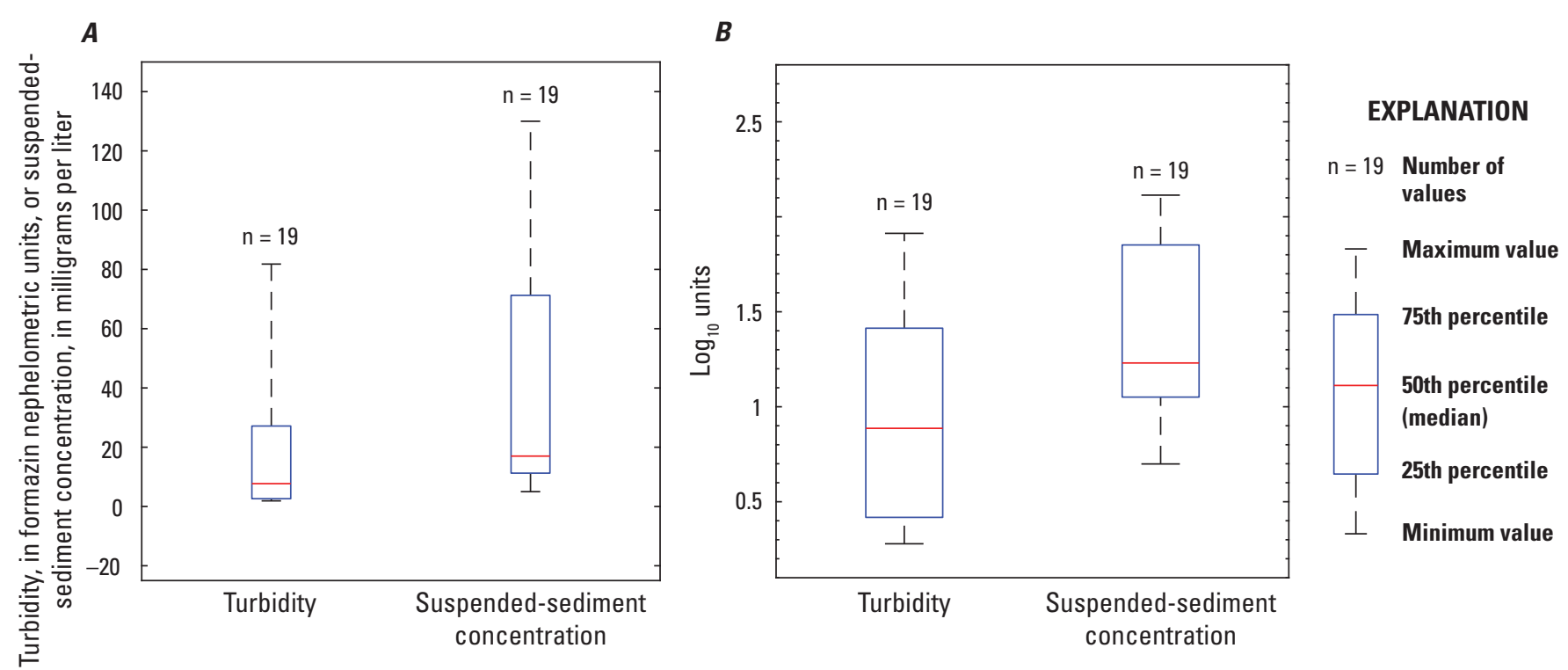

Figure 1.21. Distribution of model variable values for data from station 375607122264701, San Francisco Bay at Richmond-San Rafael Bridge, Calif., at an elevation of 13.7 meters below mean lower low water ("lower") in $A$, linear units, and $B$, log-transformed units. Data from January 2015 to September 2017 were used. 

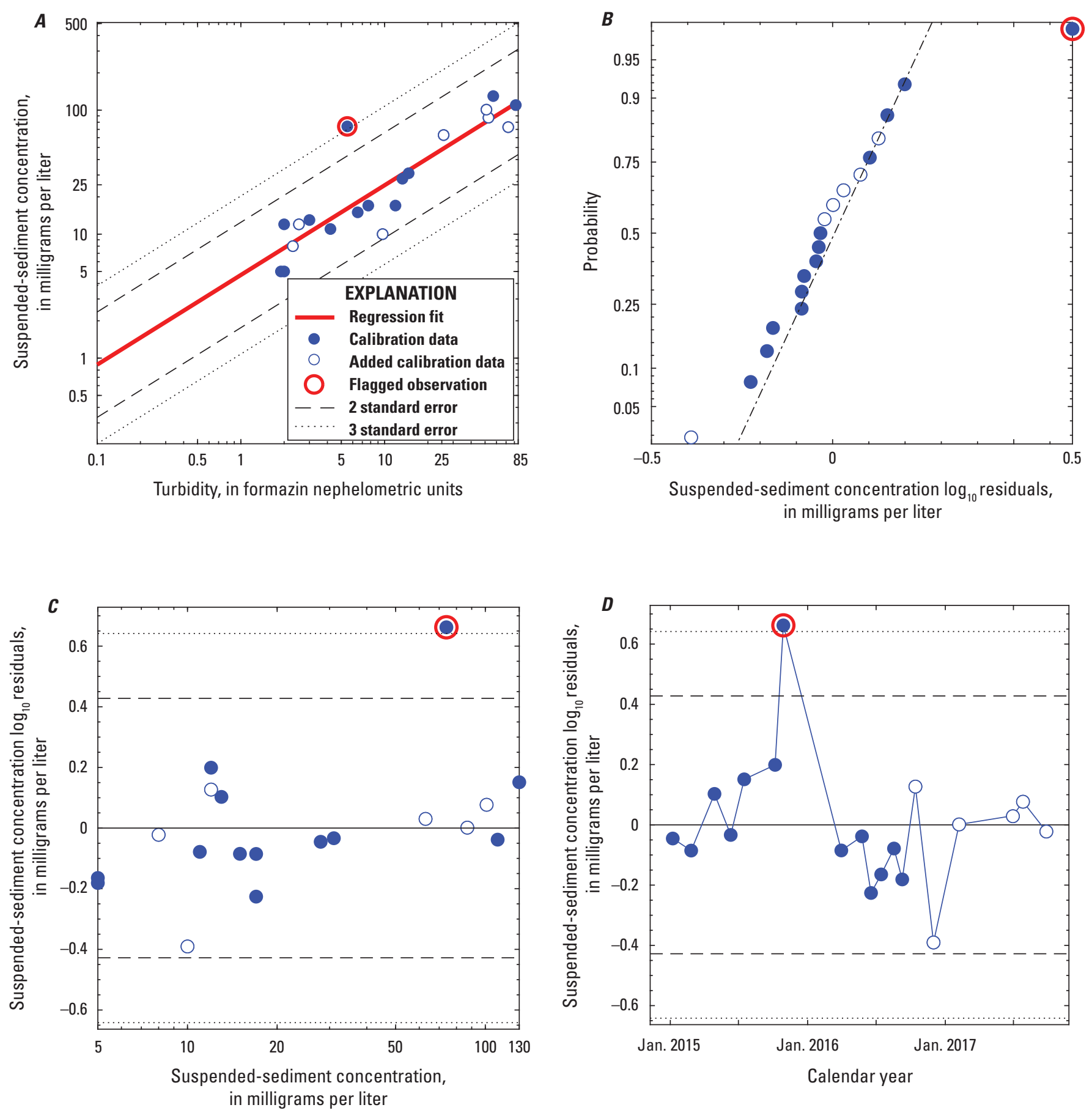

Figure 1.22. Assessment and analyses of model data for station 375607122264701, San Francisco Bay at Richmond-San Rafael Bridge, Calif., at an elevation of 13.7 meters below mean lower low water ("lower"): $A$, model calibration data and regression; $B$, normal quantile plot of model residuals; $C$, model residuals plotted against suspended-sediment concentration (SSC); and $D$, model residual time series. Data from January 2015 to September 2017 were used. 


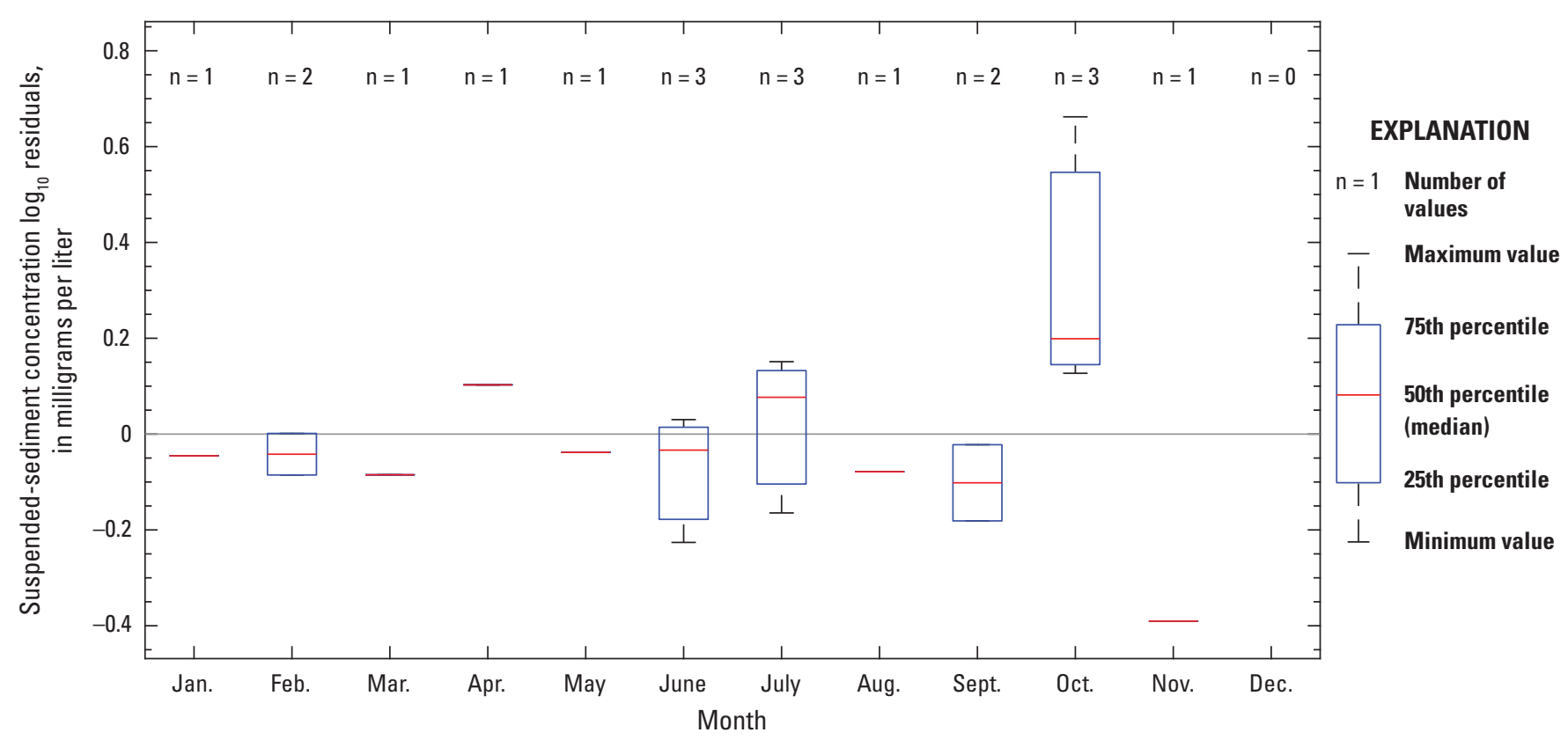

Figure 1.23. Distribution of model residuals by month for station 375607122264701, San Francisco Bay at Richmond-San Rafael Bridge, Calif., at an elevation of 13.7 meters below mean lower low water ("lower"). Data from January 2015 to September 2017 were used.

$\boldsymbol{A}$

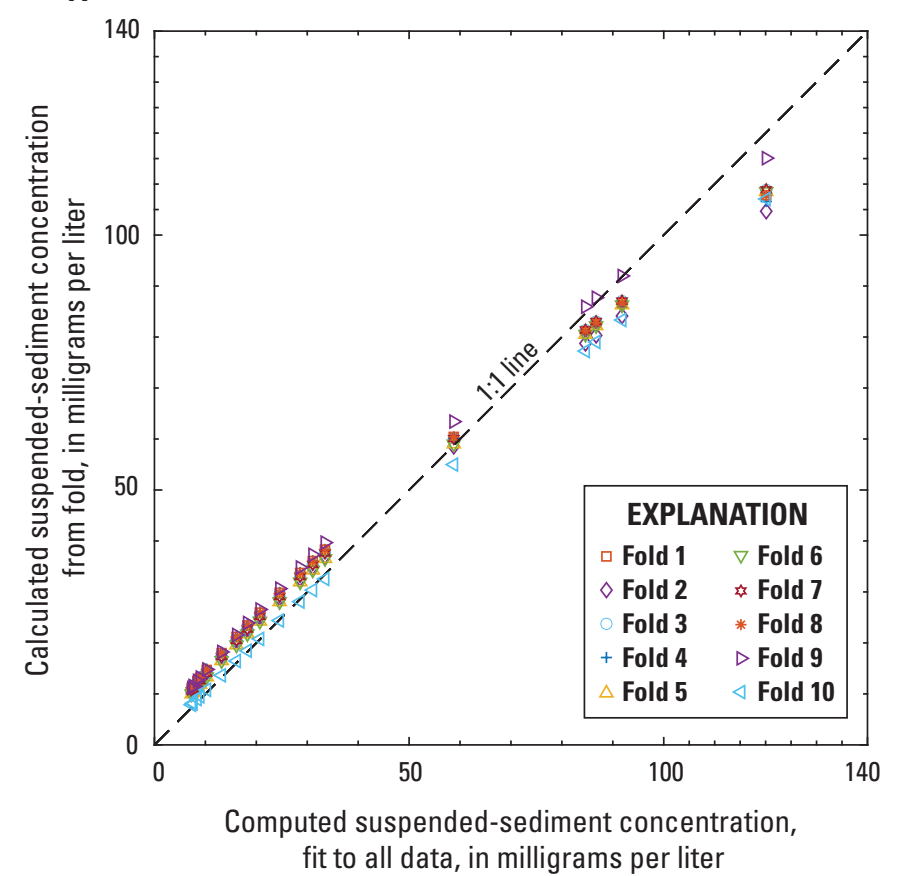

$B$

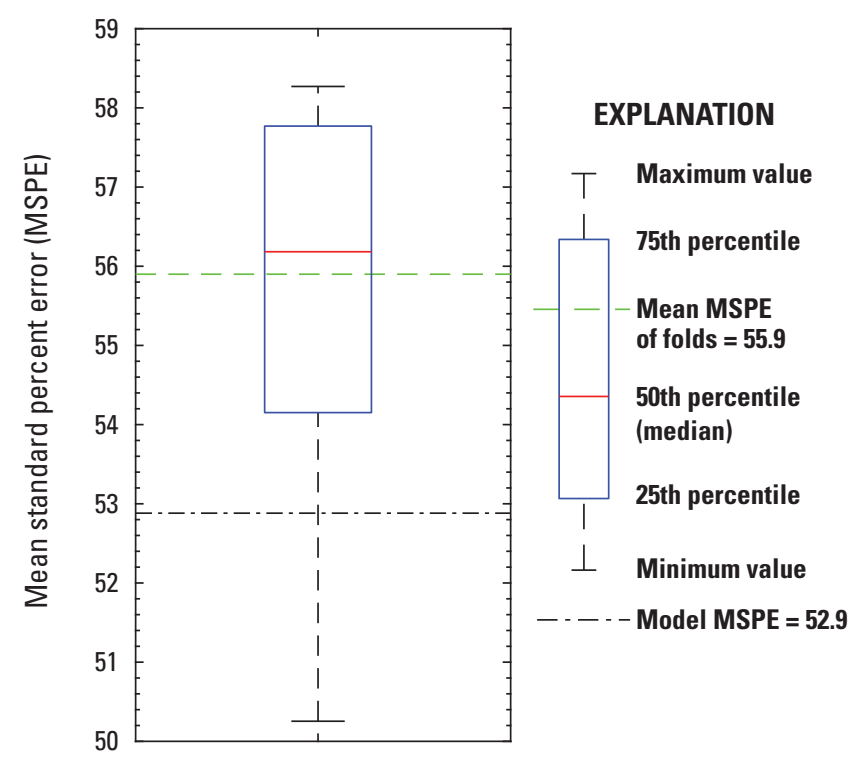

Figure 1.24. Cross-validation of model using varying subsets of for data from station 375607122264701, San Francisco Bay at Richmond-San Rafael Bridge, Calif., at an elevation of 13.7 meters below mean lower low water (“lower"): $A$, calculated suspended-sediment concentration (SSC) from cross-validation by model data subsets compared to SSC computed from model fit to all data; $B$, distribution of cross-validation subset mean standard percent error (MSPE) compared to MSPE of model fit to all data. Data from January 2015 to September 2017 were used. 
Table 1.32. Basic regression statistics for data from January 2015 to September 2017 at station 375607122264701, San Francisco Bay at Richmond-San Rafael Bridge, Calif., at an elevation of 13.7 meters below mean lower low water ("lower").

\begin{tabular}{lc}
\hline \multicolumn{1}{c}{ Number of observations } & $\mathbf{1 9}$ \\
\hline Standard error (RMSE) & 0.22 \\
Model standard percentage error (MSPE) & 52.9 \\
Coefficient of determination (R 2$)$ & 0.79 \\
Adjusted R2 (Adj. R2) & 0.77 \\
\hline
\end{tabular}

Table 1.34. Flagged observation criteria for data from January 2015 to September 2017 at station 375607122264701 , San Francisco Bay at Richmond-San Rafael Bridge, Calif., at an elevation of 13.7 meters below mean lower low water ("lower").

[Cook's D, Cook's distance; \pm , plus or minus]

\begin{tabular}{cccc}
\hline Studentized residual & Leverage & Cooks' D & DFFITS \\
\hline \pm 3 & 0.32 & 0.12 & 0.65 \\
\hline
\end{tabular}

Table 1.33. Explanatory variables, coefficients, and statistics for selected regression model for data from January 2015 to September 2017 at station 375607122264701, San Francisco Bay at Richmond-San Rafael Bridge, Calif., at an elevation of 13.7 meters below mean lower low water ("lower").

$[-$, no data $]$

\begin{tabular}{lcccc}
\hline \multicolumn{1}{c}{ Variable } & Coefficient & $\begin{array}{c}\text { Standard } \\
\text { error }\end{array}$ & t-value & p-value \\
\hline Intercept & 0.656 & 0.10 & 6.37 & $6.94 \mathrm{E}-06$ \\
Slope & 0.744 & 0.09 & 7.92 & $4.21 \mathrm{E}-07$ \\
$\begin{array}{l}\text { Bias correction } \\
\text { factor (BCF) }\end{array}$ & 1.16 & - & - & - \\
\hline
\end{tabular}

Table 1.35. Flagged observations for data from January 2015 to September 2017 at station 375607122264701, San Francisco Bay at Richmond-San Rafael Bridge, Calif., at an elevation of 13.7 meters below mean lower low water (“lower").

[mm/dd/yyy, month/day/year; hh:mm, hour:minute; FNU, formazin nephelometric units; SSC, suspended-sediment concentration; mg/l, milligrams per liter; Cook's D, Cook's distance]

\begin{tabular}{lccccccc}
\hline $\begin{array}{c}\text { Time } \\
\text { (mm/dd/yyyy hh:mm) }\end{array}$ & $\begin{array}{c}\text { Turbidity } \\
\text { (FNU) }\end{array}$ & $\begin{array}{c}\text { SSC } \\
\text { (mg/l) }\end{array}$ & $\begin{array}{c}\text { Studentized } \\
\text { residual }\end{array}$ & Leverage & Cooks' D & DFFITS \\
\hline 10/28/2015 11:45 & 5.50 & 74 & 4.58 & 0.06 & 0.31 & 1.17 \\
$04 / 05 / 2017 ~ 12: 30$ & 19.9 & 73 & 1.05 & 0.07 & 0.04 & 0.29 \\
\hline
\end{tabular}


Table 1.36. Suspended-sediment concentration model-calibration dataset for data from January 2015 to September 2017 at station 375607122264701 , San Francisco Bay at Richmond-San Rafael Bridge, Calif., at an elevation of 13.7 meters below mean lower low water ("lower").

[mm/dd/yyy, month/day/year; hh:mm, hour:minute; FNU, formazin nephelometric units; $\mathrm{mg} / \mathrm{l}$, milligrams per liter; SSC, suspended-sediment concentration; - , no data]

\begin{tabular}{|c|c|c|c|c|c|}
\hline $\begin{array}{c}\text { Time } \\
\text { (mm/dd/yyyy hh:mm) }\end{array}$ & $\begin{array}{l}\text { Turbidity } \\
\text { (FNU) }\end{array}$ & $\begin{array}{c}\text { SSC } \\
(\mathrm{mg} / \mathrm{l})\end{array}$ & $\begin{array}{c}\text { Computed SSC } \\
(\mathrm{mg} / \mathrm{l})\end{array}$ & $\begin{array}{l}\text { Residual } \\
\text { (mg/l) }\end{array}$ & $\begin{array}{c}\text { Censored } \\
\text { value }\end{array}$ \\
\hline 01/07/2015 12:30 & 13.3 & 28 & 36.0 & -8.02 & - \\
\hline $02 / 25 / 201511: 45$ & 7.70 & 17 & 24.0 & -6.99 & - \\
\hline $04 / 28 / 201510: 15$ & 3.00 & 13 & 11.9 & 1.10 & - \\
\hline 06/10/2015 14:15 & 14.7 & 31 & 38.8 & -7.81 & - \\
\hline 07/16/2015 10:15 & 57 & 130 & 106 & 23.6 & - \\
\hline $10 / 06 / 201512: 15$ & 2.00 & 12 & 8.80 & 3.20 & - \\
\hline $10 / 28 / 201511: 45$ & 5.50 & 74 & 18.7 & 55.3 & - \\
\hline $03 / 30 / 201612: 15$ & 6.50 & 15 & 21.1 & -6.15 & - \\
\hline $05 / 24 / 201611: 30$ & 81.8 & 110 & 139 & -29.2 & - \\
\hline $06 / 17 / 201612: 15$ & 11.9 & 17 & 33.2 & -16.2 & - \\
\hline 07/14/2016 12:15 & 1.90 & 5 & 8.47 & -3.47 & - \\
\hline 08/17/2016 13:00 & 4.20 & 11 & 15.3 & -4.28 & - \\
\hline $09 / 08 / 201611: 15$ & 2.00 & 5 & 8.80 & -3.80 & - \\
\hline $10 / 13 / 201611: 45$ & 2.50 & 12 & 10.4 & 1.61 & - \\
\hline $11 / 30 / 2016$ 15:00 & 9.70 & 10 & 28.5 & -18.5 & - \\
\hline 02/06/2017 14:30 & 52.8 & 87 & 100 & -13.5 & - \\
\hline $04 / 05 / 201712: 30$ & 19.9 & 73 & 48.6 & 24.4 & Outlier \\
\hline 06/29/2017 13:30 & 31.3 & 63 & 68.1 & -5.10 & - \\
\hline $07 / 26 / 201710: 45$ & 51.1 & 101 & 98.1 & 2.93 & - \\
\hline 09/26/2017 12:00 & 2.30 & 8 & 9.76 & -1.76 & - \\
\hline
\end{tabular}

Date model was created: November 26, 2018

Model application date: October 1, 2016, onward

Analyzed by Daniel Livsey, CAWSC, November 26, 2018

Approved by Maureen Downing-Kunz, CAWSC, November 26, 2018 


\section{San Francisco Bay at Alcatraz Island, Calif., Station 374938122251801; One Sensor Elevation}

Location: San Francisco Bay at Alcatraz Island, site number 374938122251801 at latitude 37²9'38” longitude $122^{\circ} 25^{\prime} 18^{\prime \prime}$ referenced to North American Datum of 1983, San Francisco County, Calif., Hydrologic Unit 18050002, unsurveyed, at end of finger pier adjacent to ferry terminal. This site is on the northeast side of Alcatraz Island in Central San Francisco Bay, $5.1 \mathrm{~km}$ from the Golden Gate. Equipment is housed in a 0.46-by-0.61-m environmental shelter attached to the north end of the pier. The station is accessed by ferry. Tides are semidiurnal, range about $1.8 \mathrm{~m}$, and follow a 14-day spring-neap cycle. Tidal currents reverse direction twice a day, with maximum speeds ranging from $0.2 \mathrm{~m} / \mathrm{s}$ in shallow water to more than $1 \mathrm{~m} / \mathrm{s}$ in deep channels. Mean lower low water (MLLW) depth is about $4.9 \mathrm{~m}$, but immediately surrounding the pier the depths increase to about $18.3 \mathrm{~m}$ MLLW.

Equipment: A YSI 6920 multi-parameter water-quality sonde equipped with specific conductance and temperature probe (YSI model 6560), turbidity (YSI model 6136), and pressure sensor for water depth above instrument (not tied to a reference elevation and not published) is deployed near mid-depth (1.8 below MLLW). Parameters are measured every 15 minutes; value reported is the average of a 12 -second burst with a sampling rate of $2 \mathrm{~Hz}$. The sensors are suspended in the water column using synthetic deployment line attached to a stainless-steel cable suspended vertically from a galvanized metal davit mounted on the pier and attached to a $54.4 \mathrm{~kg}$ weight resting on the bed. The sonde is equipped with a communication cable that connects to a datalogger (CR10X from Campbell Scientific) connected to cellular modem that allows for telemetry of data.

Water samples for SSC analysis are collected using a point sampler at the same elevation as the turbidity sensor. Cross-section surveys are not conducted at this site because of the large horizontal and vertical variability in cross-section SSC.

The regression model is based on 29 paired measurements of suspended-sediment concentration against concurrent turbidity samples collected from December 23, 2014, through September 30, 2017. Values outside of regression diagnostic criteria ranges (table 1.40) were flagged (table 1.41) and investigated as potential outliers. One sample from February 21, 2017, was excluded from the model dataset because the water-quality sonde was not deployed at the proper depth when then SSC sample was collected.

\section{Model Summary}

The final regression analysis to estimate suspended-sediment concentration for the only sensor depth at site number 374938122251801 resulted in the following model:

$$
S S C=1.90 \times T U R B^{1.10}
$$

The data and analyses used to develop the suspended-sediment concentration model for this site are summarized in tables and figures in this section (tables 1.37 to 1.42 ; figs. 1.25 to 1.28 ). 
Table 1.37. Previous and current suspended-sediment concentration model for station 374938122251801 , San Francisco Bay at Alcatraz Island, Calif., at an elevation of 1.8 meters below mean lower low water. Model coefficient computed as 10 raised to the intercept multiplied by the bias correction factor.

[SSC: suspended-sediment concentration in milligrams per liter (80154); TURB: turbidity in formazin nephelometric units (63680)]

\begin{tabular}{cll}
\hline Start date & \multicolumn{1}{c}{ End date } & \multicolumn{1}{c}{ Model } \\
\hline Oct. 01, 2015 & Jan. 12, 2016 & $\mathrm{SSC}=1.83 \times \mathrm{TURB}+9.60$ \\
Jan. 12, 2016 & Ongoing & $\mathrm{SSC}=1.90 \times \mathrm{TURB} 1.10$ \\
\hline
\end{tabular}
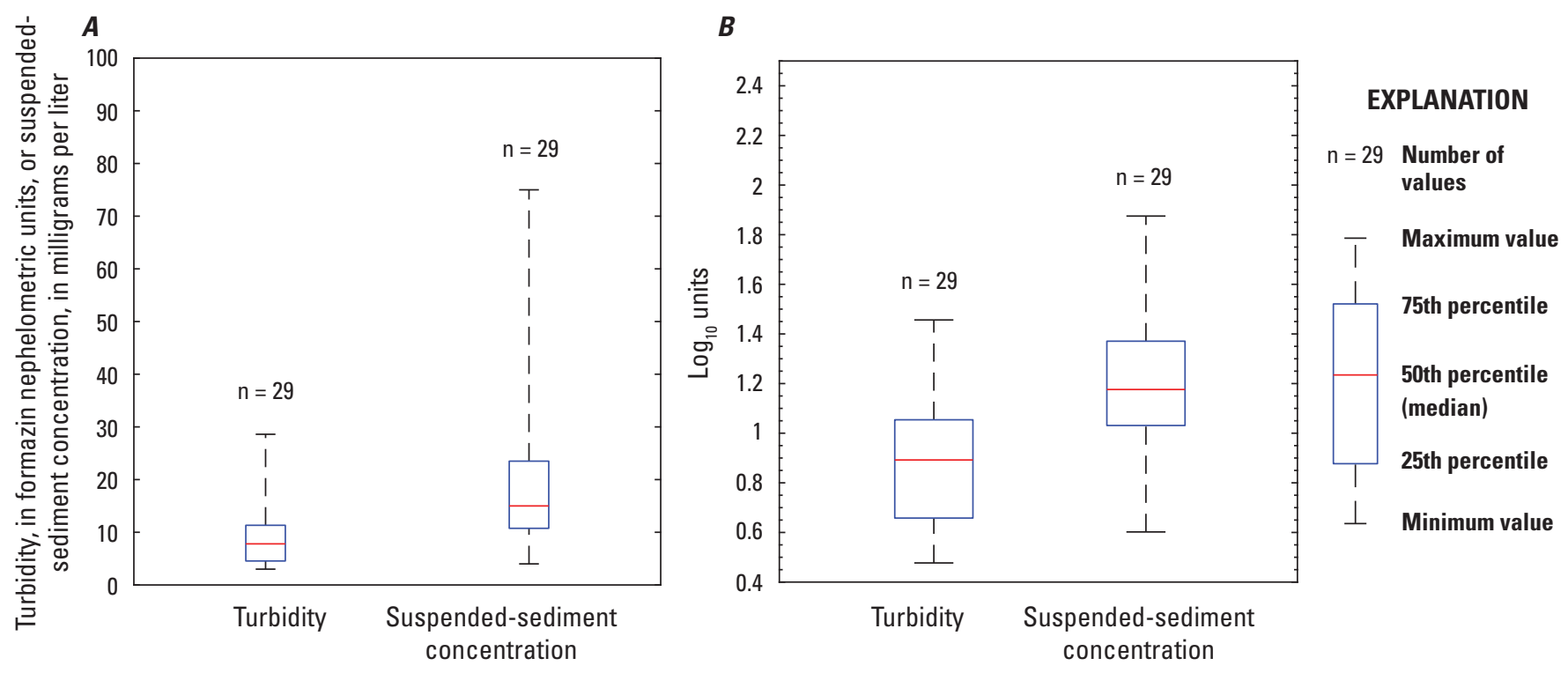

Figure 1.25. Distribution of model variable values for data from station 374938122251801, San Francisco Bay at Alcatraz Island, Calif., at an elevation of 1.8 meters below mean lower low water in $A$, linear units, and $B$, log-transformed units. Data from December 2014 to September 2017 were used. 

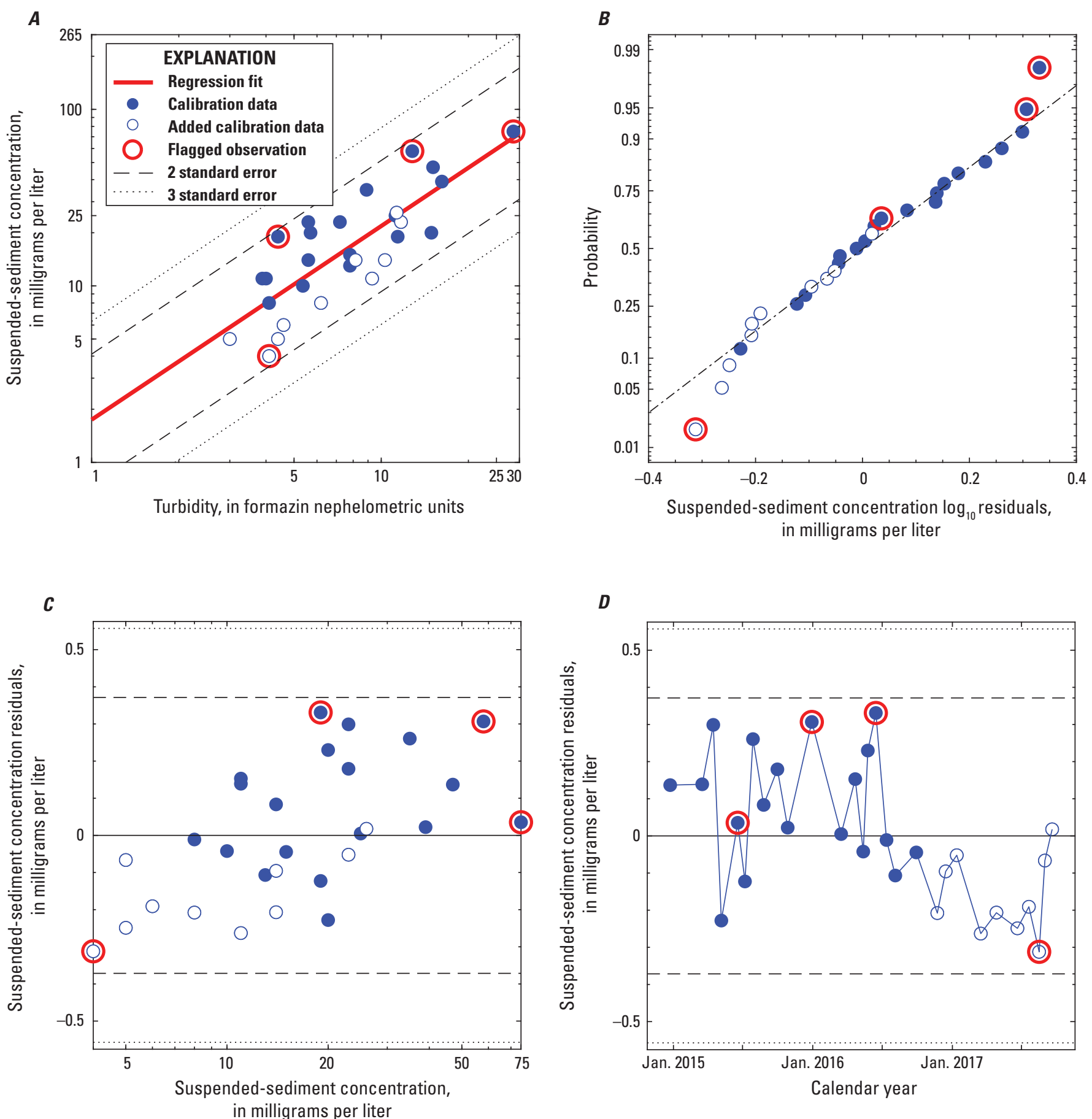

Figure 1.26. Assessment and analyses of model data for station 374938122251801, San Francisco Bay at Alcatraz Island, Calif., at an elevation of 1.8 meters below mean lower low water: $A$, model calibration data and regression; $B$, model residuals plotted against suspended-sediment concentration (SSC); $C$, Model residuals plotted against SSC; and $D$, model residual time series. Data from December 2014 to September 2017 were used. 


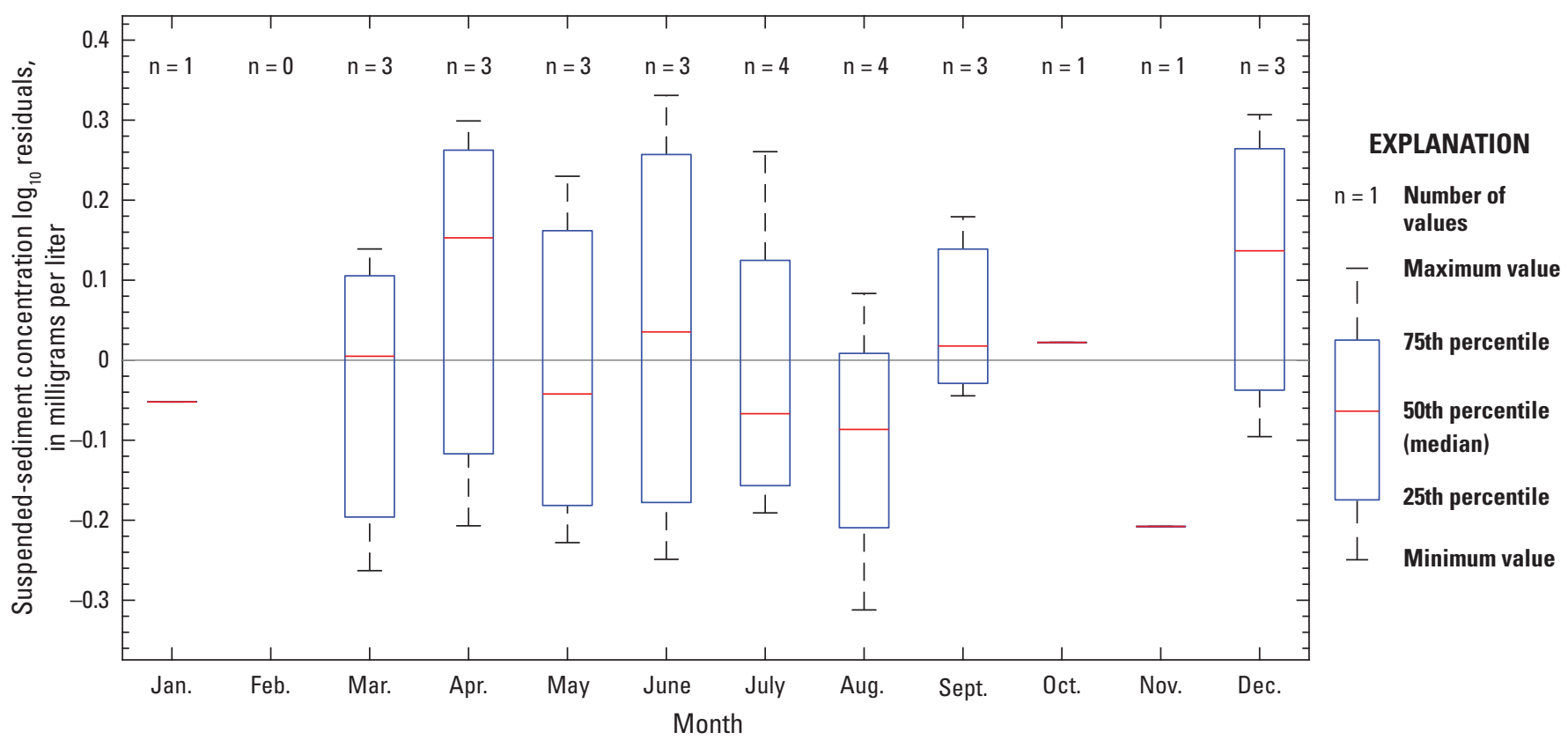

Figure 1.27. Distribution of model residuals by month for station 374938122251801, San Francisco Bay at Alcatraz Island, Calif., at an elevation of 1.8 meters below mean lower low water. Data from December 2014 to September 2017 were used.
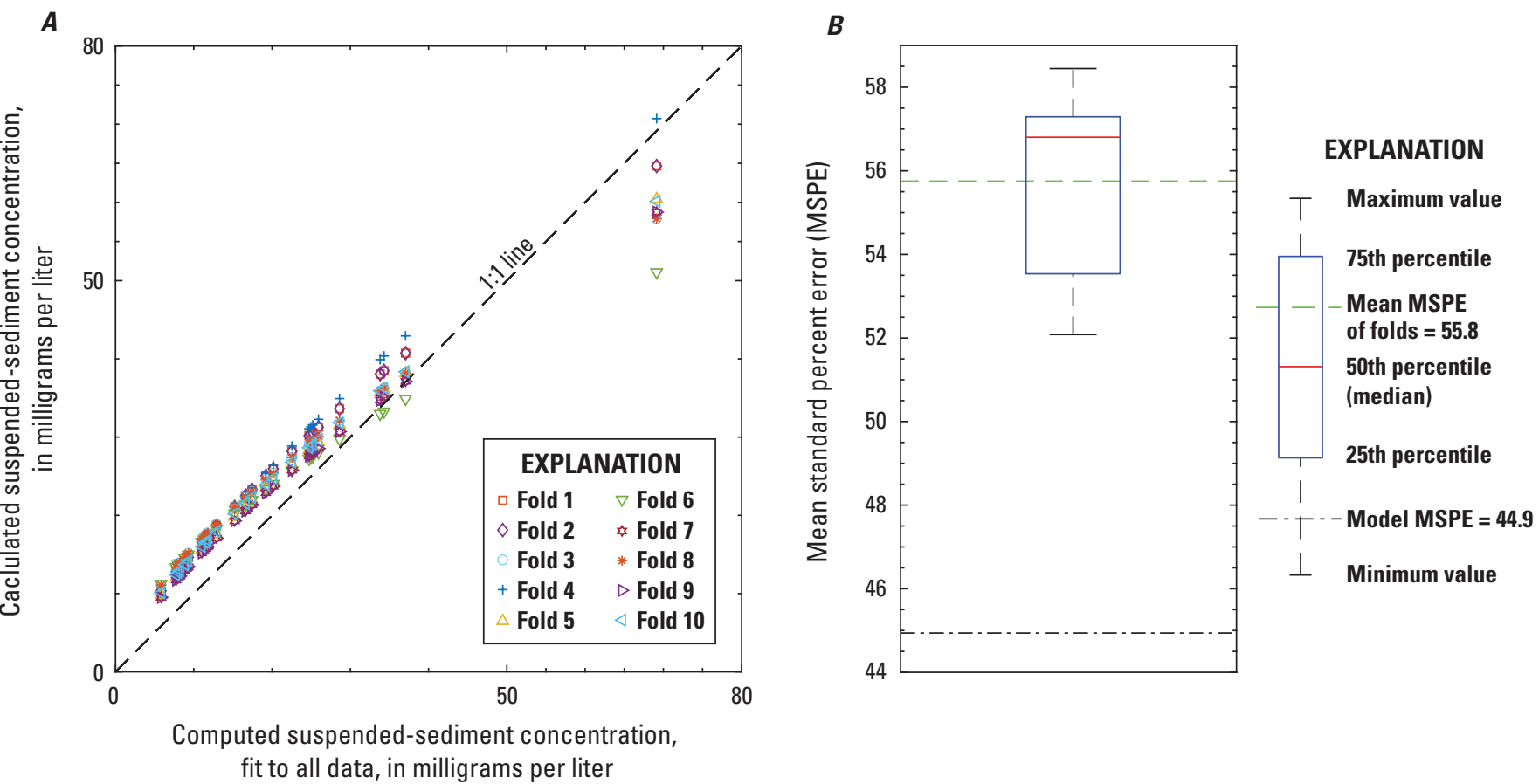

Figure 1.28. Cross-validation of model using varying subsets of for data from station 374938122251801, San Francisco Bay at Alcatraz Island, Calif., at an elevation of 1.8 meters below mean lower low water: $A$, calculated suspended-sediment concentration (SSC) from cross-validation by model data subsets compared to SSC computed from model fit to all data; $B$, distribution of cross-validation subset mean standard percent error (MSPE) compared to MSPE of model fit to all data. Data from December 2014 to September 2017 were used. 
Table 1.38. Basic regression statistics for data from December 2014 to September 2017 at station 374938122251801 , San Francisco Bay at Alcatraz Island, Calif., at an elevation of 1.8 meters below mean lower low water.

\begin{tabular}{lc}
\hline \multicolumn{1}{c}{ Number of observations } & $\mathbf{2 9}$ \\
\hline Standard error (RMSE) & 0.19 \\
Model standard percentage error (MSPE) & 44.9 \\
Coefficient of determination (R 2$)$ & 0.66 \\
Adjusted R2 (Adj. R²) & 0.64 \\
\hline
\end{tabular}

Table 1.40. Flagged observation criteria for data from December 2014 to September 2017 at station 374938122251801, San Francisco Bay at Alcatraz Island, Calif., at an elevation of 1.8 meters below mean lower low water.

[Cook's D, Cook's distance; \pm , plus or minus]

\begin{tabular}{cccc}
\hline Studentized residual & Leverage & Cooks' D & DFFITS \\
\hline \pm 3 & 0.21 & 0.10 & 0.53 \\
\hline
\end{tabular}

Table 1.39. Explanatory variables, coefficients, and statistics for selected regression model for data from December 2014 to September 2017 at station 374938122251801, San Francisco Bay at Alcatraz Island, Calif., at an elevation of 1.8 meters below mean lower low water.

$[-$, no data $]$

\begin{tabular}{lcccc}
\hline \multicolumn{1}{c}{ Variable } & Coefficient & $\begin{array}{c}\text { Standard } \\
\text { error }\end{array}$ & t-value & p-value \\
\hline Intercept & 0.242 & 0.14 & 1.74 & 0.09 \\
Turbidity & 1.10 & 0.15 & 7.18 & $1.01 \mathrm{E}-07$ \\
$\begin{array}{c}\text { Bias correction } \\
\text { factor (BCF) }\end{array}$ & 1.09 & - & - & - \\
\hline
\end{tabular}

Table 1.41. Flagged observations for data from December 2014 to September 2017 at station 374938122251801, San Francisco Bay at Alcatraz Island, Calif., at an elevation of 1.8 meters below mean lower low water.

[mm/dd/yyy, month/day/year; hh:mm, hour:minute; FNU, formazin nephelometric units; SSC, suspended-sediment concentration; mg/l, milligrams per liter; Cook's D, Cook's distance]

\begin{tabular}{lcccccc}
\hline $\begin{array}{c}\text { Time } \\
\text { (mm/dd/yyyy hh:mm) }\end{array}$ & $\begin{array}{c}\text { Turbidity } \\
\text { (FNU) }\end{array}$ & $\begin{array}{c}\text { SSC } \\
\text { (mg/l) }\end{array}$ & $\begin{array}{c}\text { Studentized } \\
\text { residual }\end{array}$ & Leverage & Cooks' D & DFFITS \\
\hline $06 / 18 / 201509: 30$ & 28.6 & 75 & 0.21 & 0.25 & $7.92 \mathrm{E}-03$ & 0.12 \\
12/29/2015 14:00 & 12.8 & 58 & 1.74 & 0.07 & 0.11 & 0.47 \\
$06 / 14 / 201609: 45$ & 4.40 & 19 & 1.90 & 0.07 & 0.13 & 0.52 \\
$02 / 21 / 201711: 00$ & 40.2 & 39 & -1.85 & 0.28 & 0.60 & -1.14 \\
$08 / 16 / 201709: 00$ & 4.10 & 4 & -1.79 & 0.08 & 0.13 & -0.53 \\
\hline
\end{tabular}


Table 1.42. Suspended-sediment concentration model-calibration dataset for data from December 2014 to September 2017 at station 374938122251801, San Francisco Bay at Alcatraz Island, Calif., at an elevation of 1.8 meters below mean lower low water.

[mm/dd/yyy, month/day/year; hh:mm, hour:minute; FNU, formazin nephelometric units; $\mathrm{mg} / \mathrm{l}$, milligrams per liter; — no data; ]

\begin{tabular}{cccccc}
\hline $\begin{array}{c}\text { Time } \\
\text { (mm/dd/yyy hh:mm) }\end{array}$ & $\begin{array}{c}\text { Turbidity } \\
\text { (FNU) }\end{array}$ & $\begin{array}{c}\text { SSC } \\
\text { (mg/l) }\end{array}$ & $\begin{array}{c}\text { Computed SSC } \\
\text { (mg/l) }\end{array}$ & $\begin{array}{c}\text { Residual } \\
\text { (mg/l) }\end{array}$ & $\begin{array}{c}\text { Censored } \\
\text { value }\end{array}$ \\
\hline 12/23/2014 11:00 & 15.1 & 47 & 37.7 & 9.30 & - \\
03/17/2015 09:00 & 4.00 & 11 & 8.74 & 2.26 & - \\
04/15/2015 09:30 & 5.60 & 23 & 12.7 & 10.3 & - \\
05/06/2015 12:00 & 14.9 & 20 & 37.1 & -17.1 & - \\
06/18/2015 09:30 & 28.6 & 75 & 76.1 & -1.11 & - \\
07/07/2015 09:45 & 11.4 & 19 & 27.7 & -8.67 & - \\
07/28/2015 08:45 & 8.90 & 35 & 21.1 & 13.9 & - \\
08/25/2015 08:45 & 5.60 & 14 & 12.7 & 1.34 & - \\
09/30/2015 08:45 & 7.20 & 23 & 16.7 & 6.31 & - \\
10/27/2015 09:30 & 16.2 & 39 & 40.7 & -1.73 & - \\
12/29/2015 14:00 & 12.8 & 58 & 31.4 & 26.6 & - \\
03/15/2016 11:00 & 11.2 & 25 & 27.1 & -2.14 & - \\
04/21/2016 09:15 & 3.88 & 11 & 8.46 & 2.54 & - \\
05/12/2016 09:15 & 5.36 & 10 & 12.1 & -2.06 & - \\
05/24/2016 08:45 & 5.70 & 20 & 12.9 & 7.09 & - \\
06/14/2016 09:45 & 4.40 & 19 & 9.71 & 9.29 & - \\
07/12/2016 09:00 & 4.10 & 8 & 8.98 & -0.98 & - \\
08/04/2016 09:00 & 7.80 & 13 & 18.2 & -5.23 & - \\
09/28/2016 09:15 & 7.80 & 15 & 18.2 & -3.23 & - \\
11/22/2016 11:00 & 6.20 & 8 & 14.2 & -6.16 & - \\
12/14/2016 10:45 & 8.15 & 14 & 19.1 & -5.13 & - \\
01/12/2017 11:15 & 11.7 & 23 & 28.5 & -5.47 & - \\
02/21/2017 11:00 & 40.2 & 39 & 111 & -71.7 & - \\
03/16/2017 08:45 & 9.30 & 11 & 22.1 & -11.1 & - \\
04/26/2017 09:30 & 10.3 & 14 & 24.7 & -10.7 & - \\
06/20/2017 09:45 & 4.40 & 5 & 9.71 & -4.71 & - \\
07/20/2017 10:15 & 4.60 & 6 & 10.2 & -4.20 & - \\
08/16/2017 09:00 & 4.10 & 4 & 8.98 & -4.98 & - \\
08/31/2017 08:30 & 3.00 & 5 & 6.37 & -1.37 & - \\
09/19/2017 09:30 & 11.3 & 26 & 27.4 & -1.40 & - \\
\hline & & & & & - \\
\hline
\end{tabular}

Date model was created: August 12, 2019

Model application date: January 12, 2017, onward

Analyzed by Daniel Livsey, CAWSC, November 26, 2018

Approved by Maureen Downing-Kunz, CAWSC, August 12, 2019 


\section{San Francisco Bay at Pier 17, Calif., Station 374811122235001, One Sensor Elevation}

Location: San Francisco Bay at Pier 17, site number 374811122235001, latitude $37^{\circ} 48^{\prime} 10.98^{\prime \prime}$ longitude $122^{\circ} 23^{\prime} 50.31^{\prime \prime}$ referenced to North American Datum of 1983, San Francisco County, Calif., Hydrologic Unit 18050002, unsurveyed, on Pier 17, $0.4 \mathrm{~km}$ east of Battery Street, $1.4 \mathrm{~km}$ southeast of North Point, $1.8 \mathrm{~km}$ northwest of Rincon Point, $2.3 \mathrm{~km}$ southwest of Yerba Buena Island, at San Francisco. This site is on the northeast corner of San Francisco's Pier 17 in Central San Francisco Bay. Equipment is housed in a 0.4-by-0.4-m environmental shelter attached to a post on the north side of the pier. The station is accessed by vehicle. Tides are semidiurnal, range about $1.8 \mathrm{~m}$, and follow a 14-day spring-neap cycle. Typical tidal currents range from $0.2 \mathrm{~m} / \mathrm{s}$ in shallow water to more than $1 \mathrm{~m} / \mathrm{s}$ in deep channels. Mean lower low water (MLLW) depth is about $4.9 \mathrm{~m}$.

Equipment: A YSI 6920 multi-parameter water-quality sonde equipped with specific conductance and temperature probe (YSI model 6560), turbidity (YSI model 6136), and pressure sensor for water depth above instrument (not tied in to a reference elevation and not published) is deployed at near-bottom ( $3.7 \mathrm{~m}$ below MLLW at $1.2 \mathrm{~m}$ above bottom). Parameters are measured every 15 minutes; value reported is the average of a 12 -second burst with a sampling rate of $2 \mathrm{~Hz}$. The sensors are suspended in the water column using synthetic deployment line attached to a stainless-steel cable suspended vertically from a galvanized metal davit mounted on the pier and attached to a $54.4 \mathrm{~kg}$ weight resting on the bed. The sonde is equipped with a communication cable that connects to a datalogger (CR1000 from Campbell Scientific) connected to cellular modem to allow for telemetry of data. Water samples for SSC analysis are collected using a point sampler at the same elevation as the turbidity sensor. Cross-section surveys are not conducted at this site because of the large horizontal and vertical variability in cross-section SSC.

The regression model is based on 32 paired measurements of suspended-sediment concentration against concurrent turbidity samples collected from December 23, 2013, through August 31, 2017. Values outside of regression diagnostic criteria ranges (table 1.46) were flagged (table 1.47) and investigated as potential outliers.

\section{Model Summary}

The final regression analysis to estimate suspended-sediment concentration for the only sensor depth at site number 374811122235001 resulted in the following model:

$$
S S C=2.53 \times T U R B+11.9
$$

The data and analyses used to develop the suspended-sediment concentration model for this site are summarized in tables and figures in this section (tables 1.43 to 1.48 ; figs. 1.29 to 1.32). 
Table 1.43. Previous and current suspended-sediment concentration model for station 374811122235001, San Francisco Bay at Pier 17, Calif., at an elevation of 3.7 meters below mean lower low water.

[SSC: suspended-sediment concentration in milligrams per liter (80154); TURB: turbidity in formazin nephelometric units (63680)]

\begin{tabular}{cll}
\hline \multicolumn{1}{c}{ Start date } & \multicolumn{1}{c}{ End date } & \multicolumn{1}{c}{ Model } \\
\hline Oct. 01, 2015 & Sept. 30, 2016 & $\mathrm{SSC}=2.54 \times \mathrm{TURB}+13.9$ \\
Oct. 01, 2016 & Ongoing & $\mathrm{SSC}=2.53 \times \mathrm{TURB}+11.9$ \\
\hline
\end{tabular}
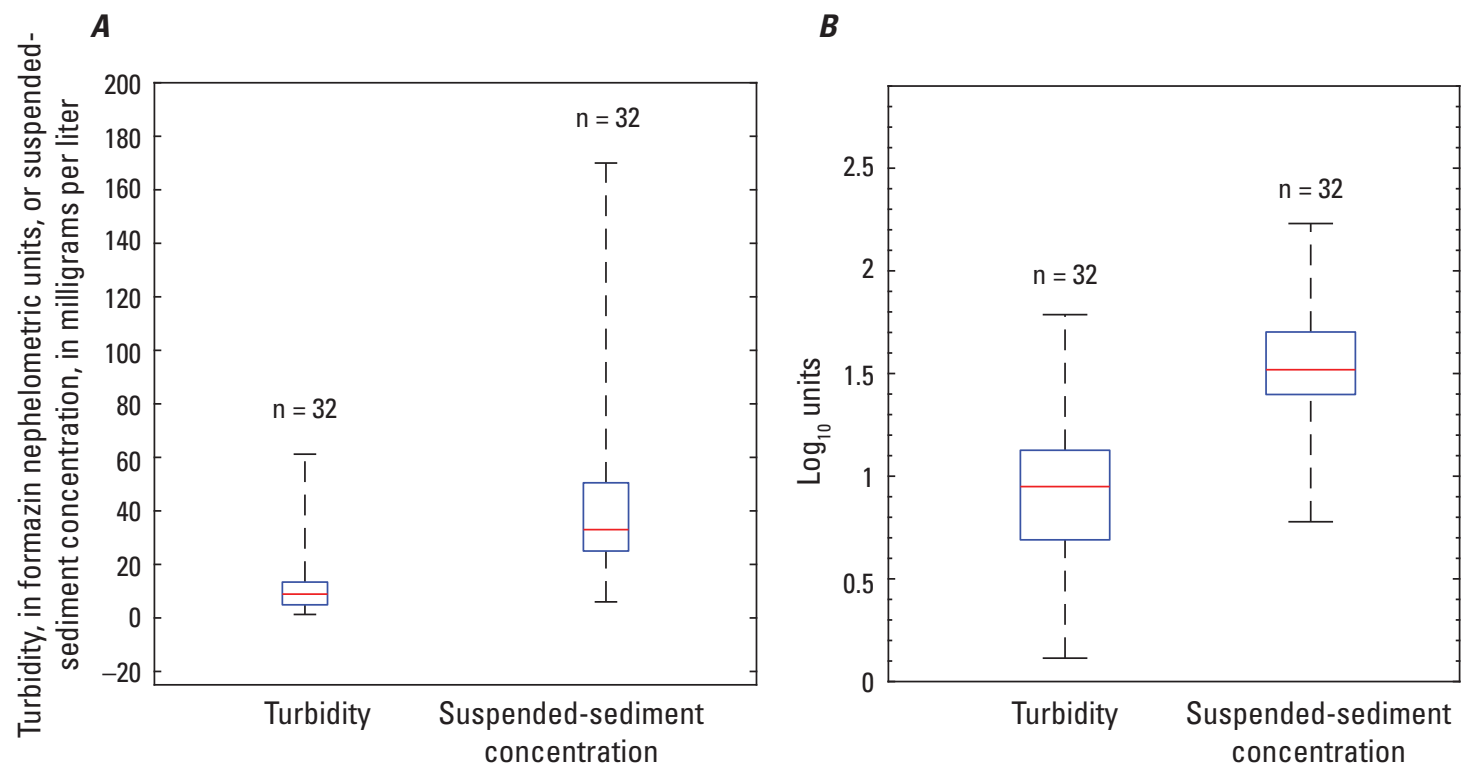

EXPLANATION

$\mathrm{n}=32$ Number of values

I

1 75th percentile 50th percentile (median)

25th percentile

$\perp \quad$ Minimum value

Figure 1.29. Distribution of model variable values for data from station 374811122235001, San Francisco Bay at Pier 17, Calif., at an elevation of 3.7 meters below mean lower low water in $A$, linear units, and $B$, log-transformed units. Data from December 2013 to September 2017 were used. 

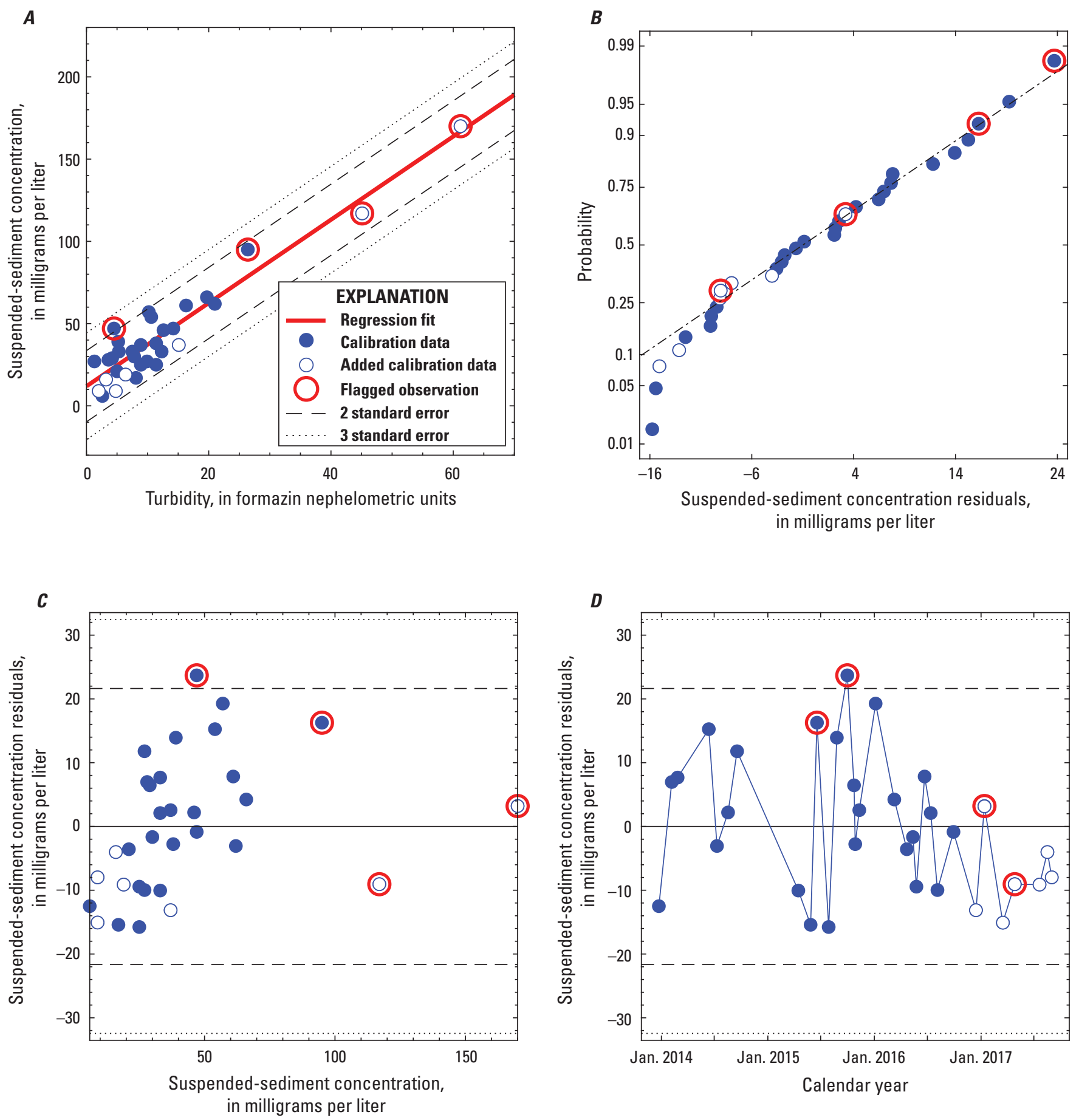

Figure 1.30. Assessment and analyses of model data for station 374811122235001, San Francisco Bay at Pier 17, Calif., at an elevation of 3.7 meters below mean lower low water: $A$, model calibration data and regression; $B$, normal quantile plot of model residuals; $C$, model residuals plotted against suspended-sediment concentration (SSC); and $D$, model residual time series. Data from December 2013 to September 2017 were used. 


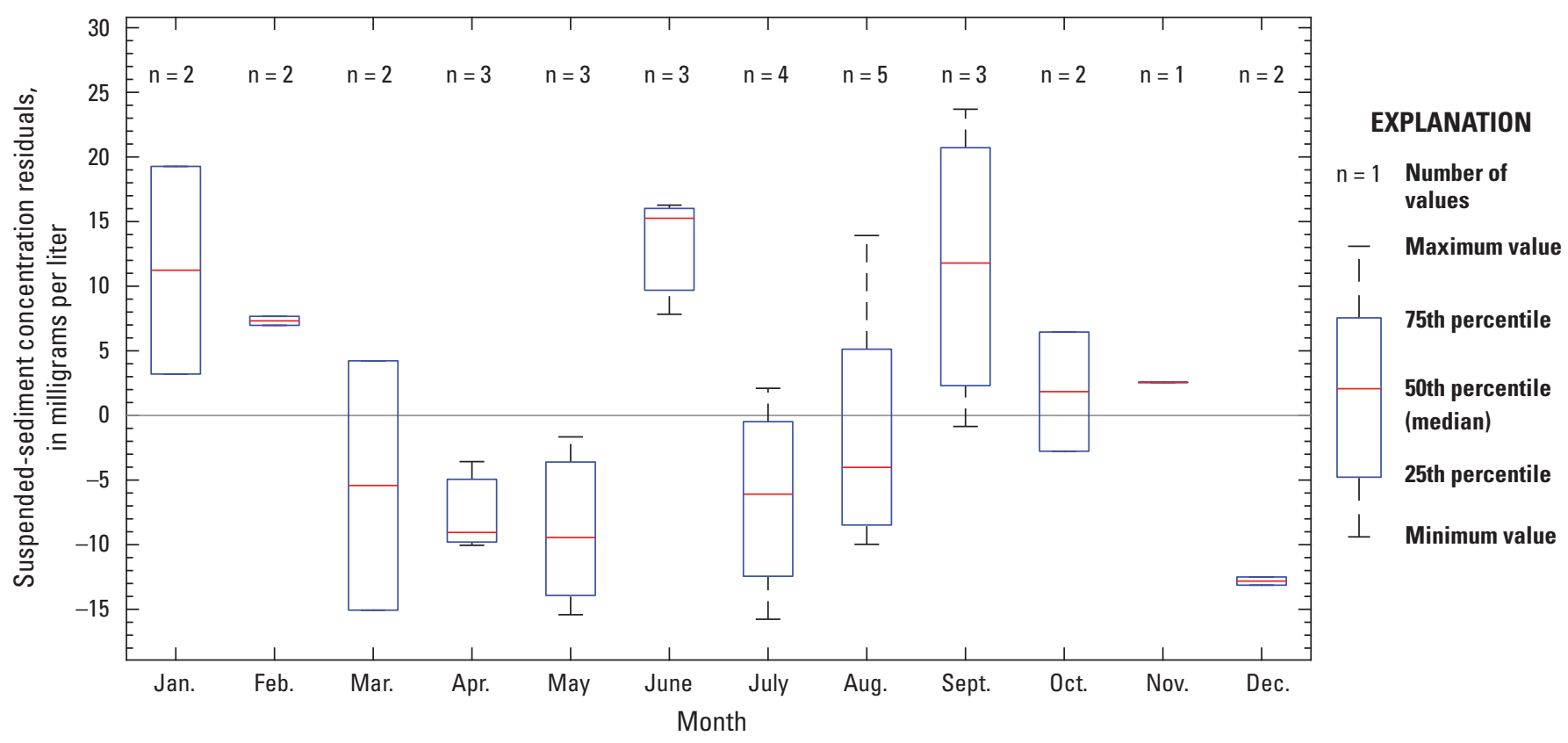

Figure 1.31. Distribution of model residuals by month by station 374811122235001 , San Francisco Bay at Pier 17, Calif., at an elevation of 3.7 meters below mean lower low water. Data from December 2013 to September 2017 were used.
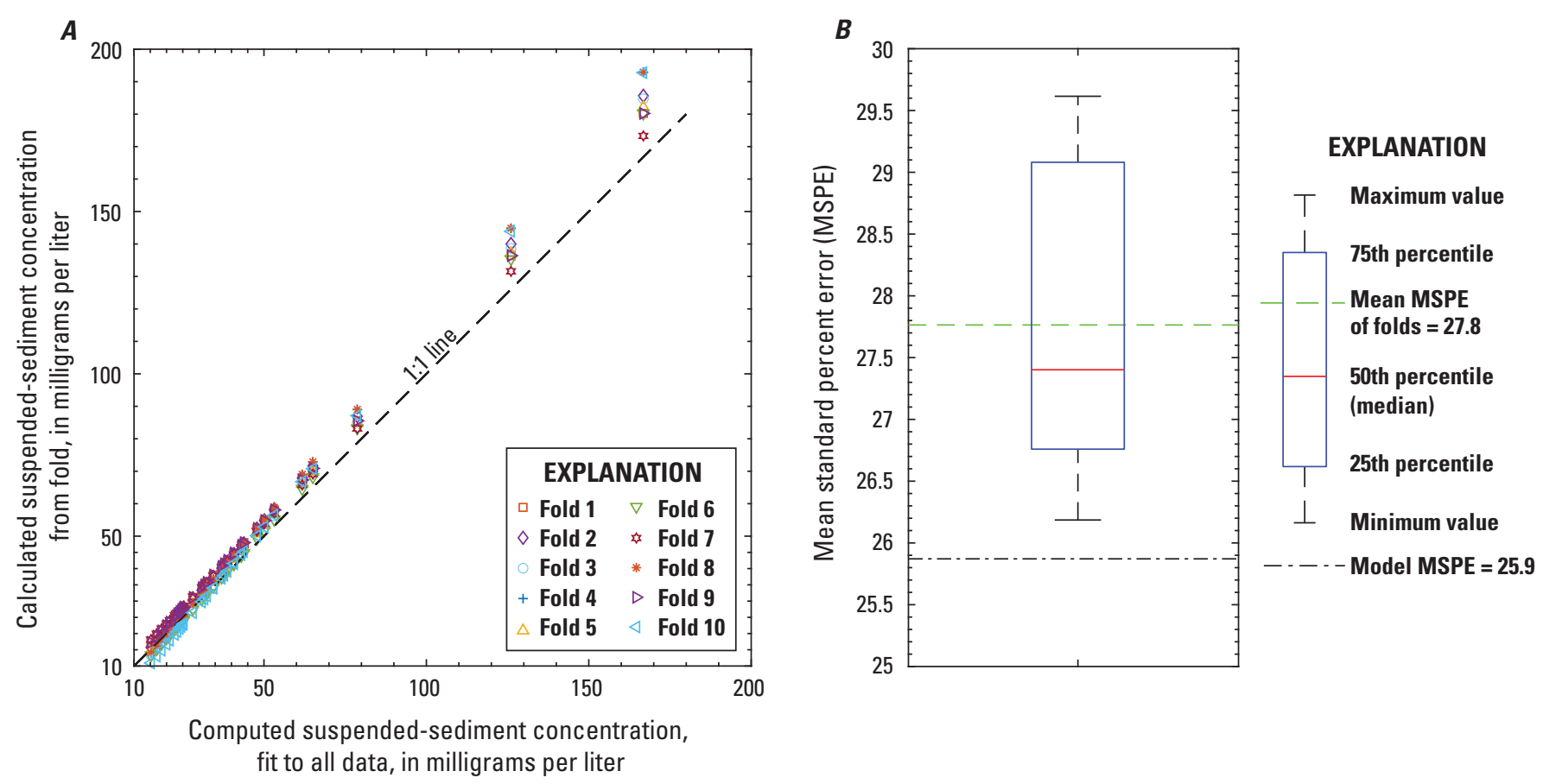

Figure 1.32. Cross-validation of model using varying subsets of for data from station 374811122235001, San Francisco Bay at Pier 17, Calif., at an elevation of 3.7 meters below mean lower low water: $A$, calculated suspended-sediment concentration (SSC) from cross-validation by model data subsets compared to SSC computed from model fit to all data; $B$, distribution of cross-validation subset mean standard percent error (MSPE) compared to MSPE of model fit to all data. Data from December 2013 to September 2017 were used. 
Table 1.44. Basic regression statistics for data from December 2013 to September 2017 at station 374811122235001 , San Francisco Bay at Pier 17, Calif., at an elevation of 3.7 meters below mean lower low water.

\begin{tabular}{lc}
\hline \multicolumn{1}{c}{ Number of observations } & $\mathbf{3 2}$ \\
\hline Standard error (RMSE) & 11.0 \\
Model standard percentage error (MSPE) & 25.9 \\
Coefficient of determination (R 2$)$ & 0.89 \\
Adjusted R2 (Adj. R 2 ) & 0.89 \\
\hline
\end{tabular}

Table 1.45. Explanatory variables, coefficients, and statistics for selected regression model for data from December 2013 to September 2017 at station 374811122235001, San Francisco Bay at Pier 17, Calif., at an elevation of 3.7 meters below mean lower low water.

\begin{tabular}{lcccc}
\hline Variable & Coefficient & Standard error & t-value & p-value \\
\hline Intercept & 11.9 & 2.73 & 4.36 & $1.42 \mathrm{E}-04$ \\
Slope & 2.53 & 0.16 & 15.9 & $3.70 \mathrm{E}-16$ \\
\hline
\end{tabular}

Table 1.46. Flagged observation criteria for data from December 2013 to September 2017 at station 374811122235001 , San Francisco Bay at Pier 17, Calif., at an elevation of 3.7 meters below mean lower low water.

[Cook’s D, Cook’s distance; \pm , plus or minus]

\begin{tabular}{cccc}
\hline Studentized residual & Leverage & Cooks' D & DFFITS \\
\hline \pm 3 & 0.19 & 0.09 & 0.50 \\
\hline
\end{tabular}

Table 1.47. Flagged observations for data from December 2013 to September 2017 at station 374811122235001, San Francisco Bay at Pier 17, Calif., at an elevation of 3.7 meters below mean lower low water.

$[\mathrm{mm} / \mathrm{dd} / \mathrm{yyy}$, month/day/year; hh:mm, hour:minute; FNU, formazin nephelometric units; SSC, suspended-sediment concentration; mg/l, milligrams per liter; Cook's D, Cook's distance]

\begin{tabular}{lcccccc}
\hline $\begin{array}{c}\text { Time } \\
\text { (mm/dd/yyyy hh:mm) }\end{array}$ & $\begin{array}{c}\text { Turbidity } \\
\text { (FNU) }\end{array}$ & $\begin{array}{c}\text { SSC } \\
\text { (mg/l) }\end{array}$ & $\begin{array}{c}\text { Studentized } \\
\text { residual }\end{array}$ & Leverage & Cooks' D & DFFITS \\
\hline 06/18/2015 13:00 & 26.4 & 95 & 1.58 & 0.07 & 0.09 & 0.45 \\
09/30/2015 11:15 & 4.50 & 47 & 2.37 & 0.04 & 0.11 & 0.50 \\
01/12/2017 13:30 & 61.2 & 170 & 0.42 & 0.54 & 0.11 & 0.46 \\
04/26/2017 12:45 & 45.1 & 117 & -0.96 & 0.26 & 0.16 & -0.57 \\
\hline
\end{tabular}


Table 1.48. Model-calibration dataset for data from December 2013 to September 2017 at station 374811122235001, San Francisco Bay at Pier 17, Calif., at an elevation of 3.7 meters below mean lower low water.

[mm/dd/yyy, month/day/year; hh:mm, hour:minute; FNU, formazin nephelometric units; SSC, suspended-sediment concentration; $\mathrm{mg} / \mathrm{l}$, milligrams per liter; - , no data]

\begin{tabular}{|c|c|c|c|c|c|}
\hline $\begin{array}{c}\text { Time } \\
\text { (mm/dd/yyyy hh:mm) }\end{array}$ & $\begin{array}{l}\text { Turbidity } \\
\text { (FNU) }\end{array}$ & $\begin{array}{l}\text { SSC } \\
(\mathrm{mg} / \mathrm{l})\end{array}$ & $\begin{array}{c}\text { Computed SSC } \\
(\mathrm{mg} / \mathrm{l})\end{array}$ & $\begin{array}{l}\text { Residual } \\
\text { (mg/l) }\end{array}$ & $\begin{array}{c}\text { Censored } \\
\text { value }\end{array}$ \\
\hline $12 / 23 / 201308: 30$ & 2.60 & 6 & 18.5 & -12.5 & - \\
\hline $02 / 05 / 2014$ 13:30 & 3.60 & 28 & 21.0 & 6.97 & - \\
\hline $02 / 25 / 201414: 15$ & 5.30 & 33 & 25.3 & 7.67 & - \\
\hline $06 / 12 / 201413: 15$ & 10.6 & 54 & 38.7 & 15.3 & - \\
\hline 07/10/2014 13:15 & 21.0 & 62 & 65.1 & -3.06 & - \\
\hline 08/17/2014 13:45 & 12.6 & 46 & 43.8 & 2.20 & - \\
\hline 09/17/2014 12:45 & 1.30 & 27 & 15.2 & 11.8 & - \\
\hline $04 / 15 / 201512: 15$ & 12.3 & 33 & 43.0 & -10.0 & - \\
\hline $05 / 27 / 201515: 30$ & 8.1 & 17 & 32.4 & -15.4 & - \\
\hline 06/18/2015 13:00 & 26.4 & 95 & 78.7 & 16.3 & - \\
\hline $07 / 28 / 201513: 15$ & 11.4 & 25 & 40.8 & -15.8 & - \\
\hline $08 / 25 / 201513: 15$ & 5.20 & 39 & 25.1 & 13.9 & - \\
\hline 09/30/2015 11:15 & 4.50 & 47 & 23.3 & 23.7 & - \\
\hline 10/23/2015 11:30 & 4.20 & 29 & 22.5 & 6.45 & - \\
\hline $10 / 27 / 201514: 45$ & 11.4 & 38 & 40.8 & -2.77 & - \\
\hline $11 / 10 / 201512: 45$ & 8.90 & 37 & 34.4 & 2.56 & - \\
\hline 01/05/2016 12:30 & 10.2 & 57 & 37.7 & 19.3 & - \\
\hline 03/09/2016 12:45 & 19.7 & 66 & 61.8 & 4.23 & - \\
\hline $04 / 21 / 201612: 15$ & 5.00 & 21 & 24.6 & -3.57 & - \\
\hline 05/12/2016 11:15 & 7.80 & 30 & 31.7 & -1.66 & - \\
\hline 05/24/2016 09:45 & 8.90 & 25 & 34.4 & -9.44 & - \\
\hline 06/21/2016 11:30 & 16.3 & 61 & 53.2 & 7.83 & - \\
\hline 07/12/2016 11:30 & 7.50 & 33 & 30.9 & 2.10 & - \\
\hline 08/04/2016 11:15 & 9.90 & 27 & 37.0 & -9.97 & - \\
\hline 09/28/2016 12:30 & 14.2 & 47 & 47.9 & -0.85 & - \\
\hline $12 / 14 / 2016$ 13:45 & 15.1 & 37 & 50.1 & -13.1 & - \\
\hline 01/12/2017 13:30 & 61.2 & 170 & 167 & 3.20 & - \\
\hline 03/16/2017 11:30 & 4.80 & 9 & 24.1 & -15.1 & - \\
\hline $04 / 26 / 201712: 45$ & 45.1 & 117 & 126 & -9.05 & - \\
\hline 07/20/2017 12:45 & 6.40 & 19 & 28.1 & -9.11 & - \\
\hline 08/16/2017 11:30 & 3.20 & 16 & 20.0 & -4.02 & - \\
\hline 08/31/2017 10:45 & 2.00 & 9 & 17.0 & -7.98 & - \\
\hline
\end{tabular}

Date model was created: May 24, 2018

Model application date: October 1, 2016, onward

Analyzed by Daniel Livsey, CAWSC, May 24, 2018

Approved by Maureen Downing-Kunz, CAWSC, June 4, 2018 


\section{South San Francisco Bay at Dumbarton Bridge, Calif., Station 373015122071000; Two Sensor Elevations}

Location: Latitude $37^{\circ} 30^{\prime} 15^{\prime \prime}$ longitude $122^{\circ} 07^{\prime} 10^{\prime \prime}$ referenced to North American Datum of 1927, San Mateo County, CA, Hydrologic Unit 18050004, unsurveyed, on Pier 23 of the Dumbarton Bridge (State Route 84), west side of ship navigation channel. Equipment is housed in a $0.9-$ by- $0.6-\mathrm{m}$ shelter on the east side of the pier. The station is accessed by boat. Tides are semidiurnal, a range about $3.0 \mathrm{~m}$, and follow a 14-day spring-neap cycle. Tidal currents reverse direction twice a day, and maximum speeds range from $0.2 \mathrm{~m} / \mathrm{s}$ in shallow water to more than $1 \mathrm{~m} / \mathrm{s}$ in deep channels. Mean lower low water (MLLW) depth is about $13.7 \mathrm{~m}$.

Equipment: YSI 6920 multi-parameter water-quality sondes equipped with specific conductance and temperature probe (YSI model 6560), turbidity (YSI model 6136), and pressure sensor for water depth above instrument (not tied in to a reference elevation and not published) are deployed at two depths: mid-depth (6.1 m below MLLW) and near-bottom (12.5 m below MLLW at $1.2 \mathrm{~m}$ above bottom). Parameters are measured every 15 minutes; value reported is the average of a 12-second burst with a sampling rate of $2 \mathrm{~Hz}$. The sensors are suspended in the water column using synthetic deployment line attached to a stainless-steel cable suspended vertically from a galvanized metal davit mounted on the pier and attached to a $68-\mathrm{kg}$ weight resting on the bed. Each sonde is equipped with a communication cable that connects to a datalogger (CR1000 from Campbell Scientific) connected to cellular modem to allow for telemetry of data.

Water samples for SSC analysis are collected using a point sampler at the same elevation as the turbidity sensor. Cross-section surveys are not conducted at this site because of the large horizontal and vertical variability in cross-section SSC.

\section{Model Summary for Suspended-Sediment Concentration at Station 373015122071000 South San Francisco Bay at Dumbarton Bridge, Calif., Elevation of 6.1 Meters Below Mean Lower Low Water ("Upper")}

The regression model is based on 32 paired measurements of suspended-sediment concentration against concurrent turbidity samples collected from February 11, 2015, through September 20, 2017. Values outside of regression diagnostic criteria ranges (table 1.52) were flagged (table 1.53) and investigated as potential outliers.

The final regression analysis to estimate suspended-sediment concentration at site number 373015122071000 "upper" resulted in the following model:

$$
S S C=1.68 \times T U R B+7.92
$$

The data and analyses used to develop the suspended-sediment concentration model for this site are summarized in tables and figures in this section (tables 1.49 to 1.54 ; figs. 1.33 to 1.36). 
Table 1.49. Previous and current suspended-sediment concentration models for station 373015122071000, South San

Francisco Bay at Dumbarton Bridge, Calif., elevation of 6.1 meters below mean lower low water ("upper").

[SSC: suspended-sediment concentration in milligrams per liter (80154); TURB: turbidity in formazin nephelometric units (63680)]

\begin{tabular}{cll}
\hline \multicolumn{1}{c}{ Start date } & \multicolumn{1}{c}{ End date } & \multicolumn{1}{c}{ Model } \\
\hline Oct. 01,2014 & Sep. 30,2016 & $\mathrm{SSC}=4.23 \times$ TURB 0.839 \\
Oct. 01,2016 & Ongoing & $\mathrm{SSC}=1.68 \times \mathrm{TURB}+9.72$ \\
\hline
\end{tabular}
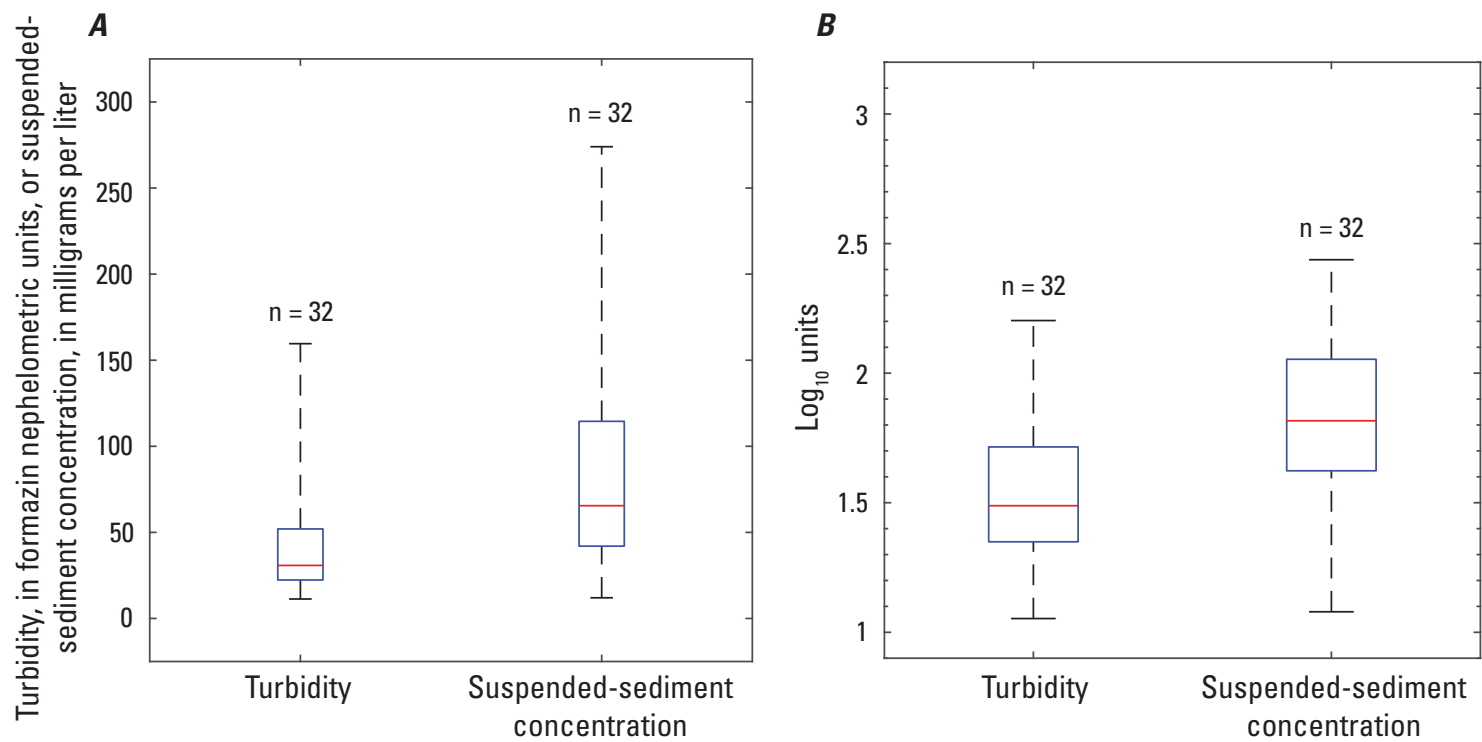

EXPLANATION

$\mathrm{n}=32$ Number of values

- Maximum value

1 75th percentile

50th percentile (median)

25th percentile

$\perp \quad$ Minimum value

Figure 1.33. Distribution of model variable values for data from station 373015122071000 , South San Francisco Bay at Dumbarton Bridge, Calif., elevation of 6.1 meters below mean lower low water ("upper") in $A$, linear units, and $B$, log-transformed units. Data from February 2015 to September 2017 were used. 

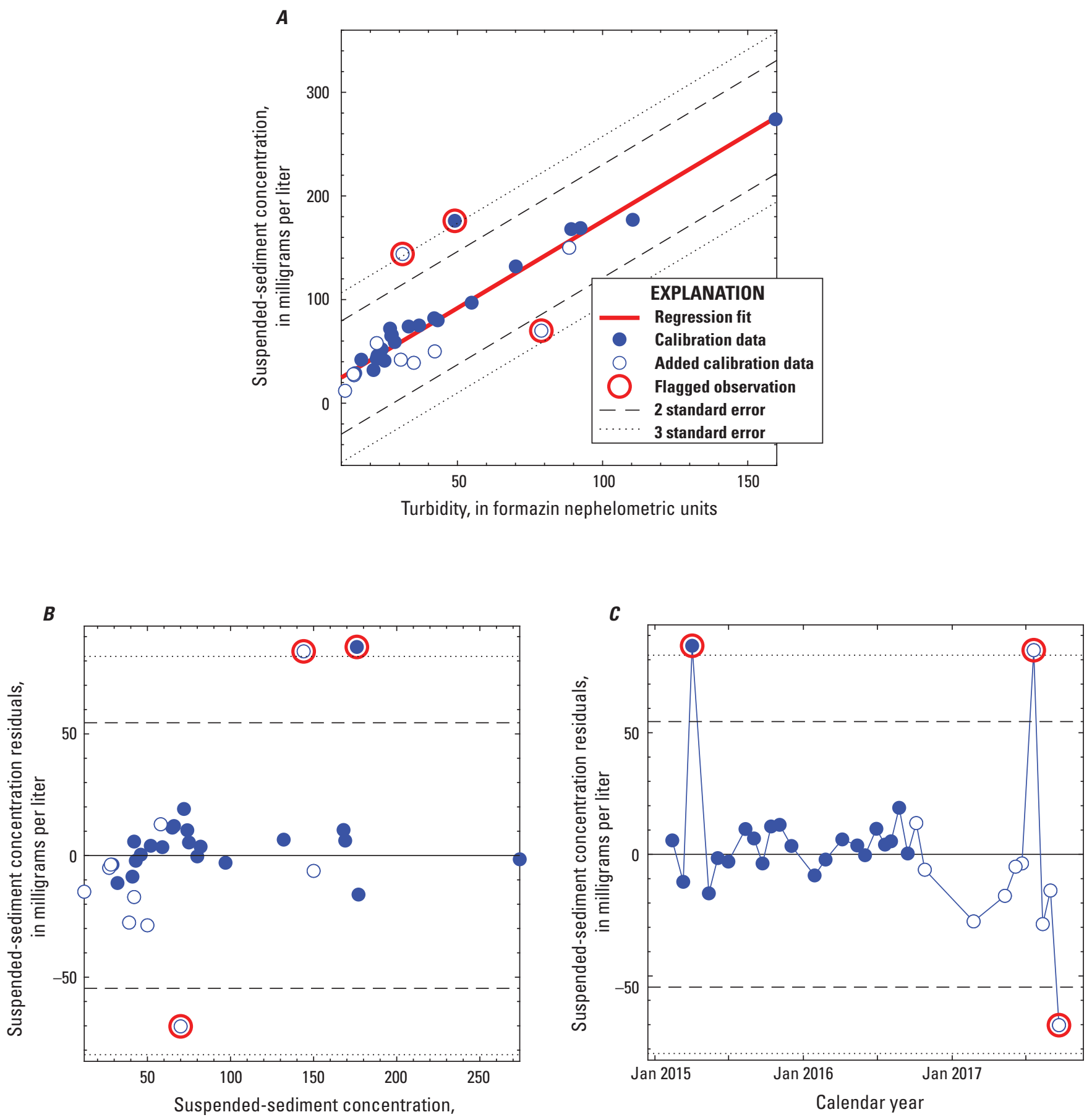

Figure 1.34. Assessment and analyses of model data for station 373015122071000 , South San Francisco Bay at Dumbarton Bridge, Calif., elevation of 6.1 meters below mean lower low water ("upper"): $A$, model calibration data and regression; $B$, model residuals plotted against suspended-sediment concentration (SSC); and $C$, model residual time series. Data from February 2015 to September 2017 were used. 


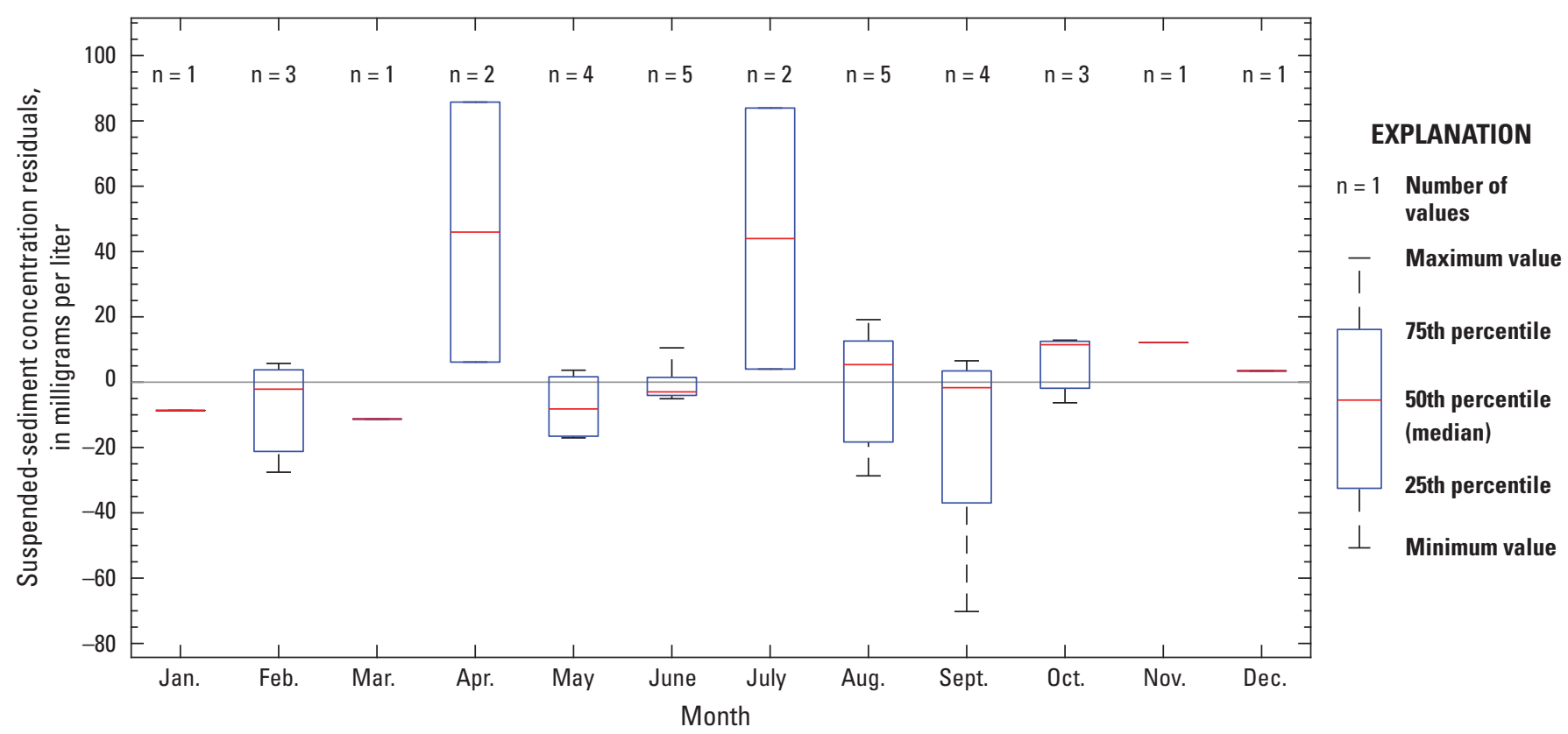

Figure 1.35. Distribution of model residuals by month for station 373015122071000, South San Francisco Bay at Dumbarton Bridge, Calif., elevation of 6.1 meters below mean lower low water ("upper"). Data from February 2015 to September 2017 were used.
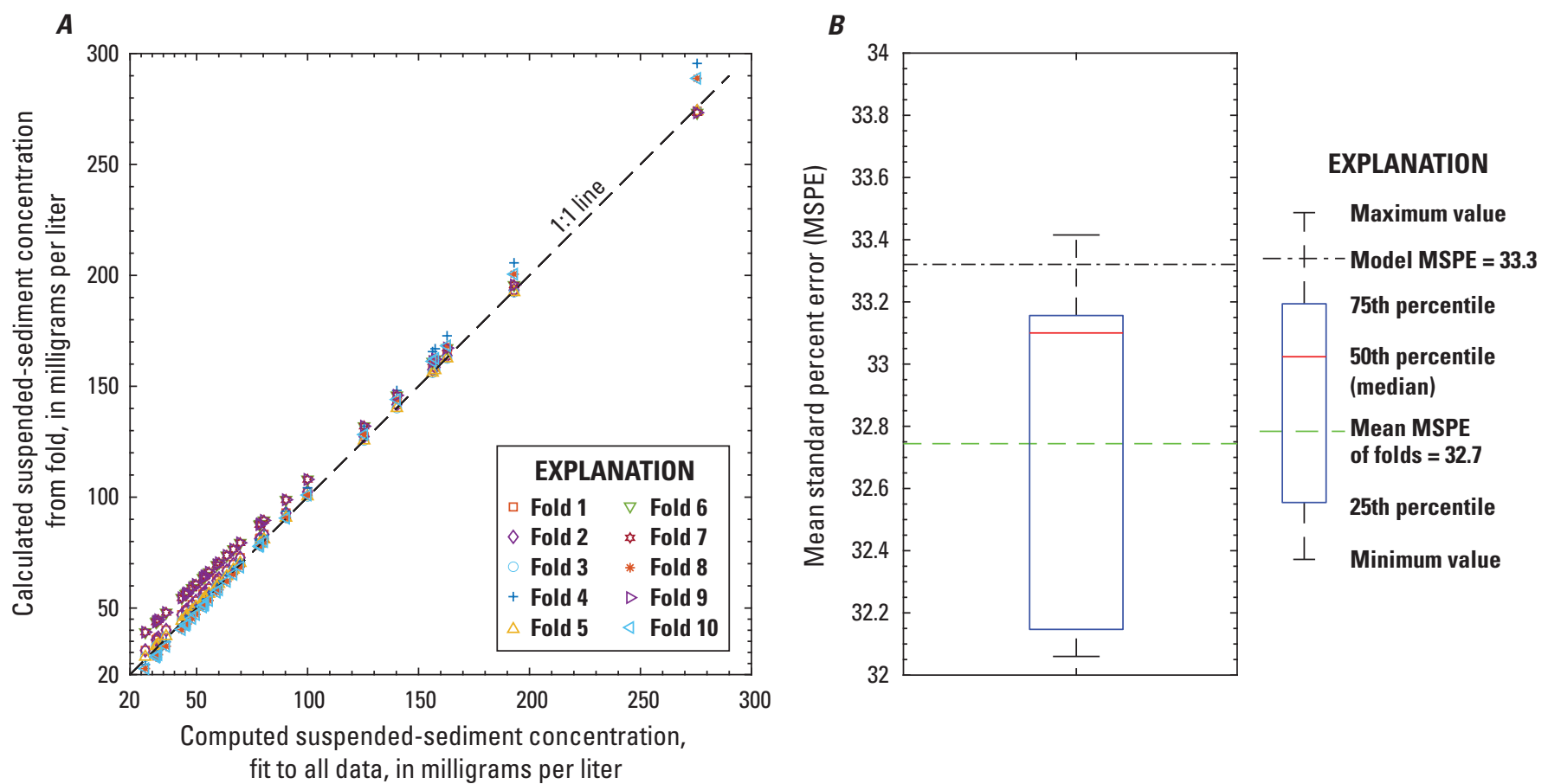

Figure 1.36. Cross-validation of model using varying subsets of for data from station 373015122071000 , South San Francisco Bay at Dumbarton Bridge, Calif., elevation of 6.1 meters below mean lower low water ("upper"): $A$, calculated suspended-sediment concentration (SSC) from cross-validation by model data subsets compared to SSC computed from model fit to all data; $B$, distribution of cross-validation subset mean standard percent error (MSPE) compared to MSPE of model fit to all data. Data from February 2015 to September 2017 were used. 
Table 1.50. Basic regression statistics for data from February 2015 to September 2017 at station 373015122071000 , South San Francisco Bay at Dumbarton Bridge, Calif., elevation of 6.1 meters below mean lower low water ("upper").

\begin{tabular}{lc}
\hline \multicolumn{1}{c}{ Number of observations } & $\mathbf{3 2}$ \\
\hline Standard error (RMSE) & 26.9 \\
Model standard percentage error (MSPE) & 26.9 \\
\hline
\end{tabular}

Table 1.52. Flagged observation criteria for data from February 2015 to September 2017 at station 373015122071000 ,

South San Francisco Bay at Dumbarton Bridge, Calif., elevation of 6.1 meters below mean lower low water ("upper").

[Cook's D, Cook's distance; \pm , plus or minus; - , parametric statistics do not apply to non-parametric Kendall-Theil regression (Helsel and Hirsch, 2002)]

\begin{tabular}{cccc}
\hline $\begin{array}{c}\mathbf{2} \times \text { Standard deviation of model } \\
\text { residuals }\end{array}$ & Leverage & Cooks' D & DFFITS \\
\hline \pm 54.6 & - & - & - \\
\hline
\end{tabular}

Table 1.51. Explanatory variables, coefficients, and statistics for selected regression model for data from February 2015 to September 2017.at station 373015122071000, South San Francisco Bay at Dumbarton Bridge, Calif., elevation of 6.1 meters below mean lower low water ("upper").

[-, parametric statistics do not apply to non-parametric Kendall-Theil regression (Helsel and Hirsch, 2002)]

\begin{tabular}{ccccc}
\hline Variable & Coefficient & Standard error & t-value & p-value \\
\hline Intercept & 7.92 & - & - & - \\
Turbidity & 1.68 & - & - & - \\
\hline
\end{tabular}

Table 1.53. Flagged observations for data from February 2015 to September 2017 at station 373015122071000, South San Francisco Bay at Dumbarton Bridge, Calif., elevation of 6.1 meters below mean lower low water ("upper").

[mm/dd/yyy, month/day/year; hh:mm, hour:minute; FNU, formazin nephelometric units; SSC, suspended-sediment concentration; mg/l, milligrams per liter; Cook's D, Cook's distance]

\begin{tabular}{lccc}
\hline $\begin{array}{c}\text { Time } \\
\text { (mm/dd/yyyy hh:mm) }\end{array}$ & Turbidity (FNU) & $\begin{array}{c}\text { SSC } \\
\text { (mg/l) }\end{array}$ & $\begin{array}{c}\text { Model residual } \\
\text { (mg/l) }\end{array}$ \\
\hline 04/02/2015 11:45 & 49.1 & 176 & 85.8 \\
07/20/2017 11:00 & 31.1 & 144 & 83.9 \\
09/20/2017 10:45 & 78.9 & 70 & -70.2 \\
\hline
\end{tabular}


Table 1.54. Model-calibration dataset for data from February 2015 to September 2017 at station 373015122071000, South San Francisco Bay at Dumbarton Bridge, Calif., elevation of 6.1 meters below mean lower low water ("upper").

[mm/dd/yyy, month/day/year; hh:mm, hour:minute; FNU, formazin nephelometric units; SSC, suspended-sediment concentration; mg/l, milligrams per liter; - , no data]

\begin{tabular}{|c|c|c|c|c|c|}
\hline $\begin{array}{c}\text { Time } \\
\text { (mm/dd/yyyy hh:mm) }\end{array}$ & $\begin{array}{l}\text { Turbidity } \\
\text { (FNU) }\end{array}$ & $\begin{array}{l}\text { SSC } \\
(\mathrm{mg} / \mathrm{l})\end{array}$ & $\begin{array}{c}\text { Computed SSC } \\
(\mathrm{mg} / \mathrm{l})\end{array}$ & $\begin{array}{l}\text { Residual } \\
\text { (mg/l) }\end{array}$ & $\begin{array}{c}\text { Censored } \\
\text { value }\end{array}$ \\
\hline $02 / 12 / 2015$ 14:15 & 16.9 & 42 & 36.3 & 5.75 & - \\
\hline 03/11/2015 12:30 & 21.1 & 32 & 43.3 & -11.3 & - \\
\hline 04/02/2015 11:45 & 49.1 & 176 & 90.2 & 85.8 & - \\
\hline 05/13/2015 12:45 & 110 & 177 & 193 & -16.0 & - \\
\hline 06/04/2015 08:45 & 160 & 274 & 276 & -1.54 & - \\
\hline $06 / 30 / 201513: 30$ & 54.9 & 97 & 100 & -2.97 & - \\
\hline 08/11/2015 14:00 & 33.2 & 74 & 63.6 & 10.4 & - \\
\hline 09/01/2015 12:45 & 70.1 & 132 & 125 & 6.54 & - \\
\hline 09/22/2015 13:15 & 14.8 & 29 & 32.7 & -3.73 & - \\
\hline $10 / 13 / 201512: 15$ & 27.2 & 65 & 53.5 & 11.5 & - \\
\hline $11 / 03 / 201515: 15$ & 27.4 & 66 & 53.9 & 12.1 & - \\
\hline $12 / 02 / 201514: 15$ & 28.4 & 59 & 55.6 & 3.45 & - \\
\hline 01/28/2016 13:45 & 24.9 & 41 & 49.7 & -8.67 & - \\
\hline 02/24/2016 13:00 & 22.2 & 43 & 45.1 & -2.14 & - \\
\hline 04/05/2016 15:00 & 92.4 & 169 & 163 & 6.14 & - \\
\hline $05 / 12 / 201612: 15$ & 42 & 82 & 78.3 & 3.66 & - \\
\hline $05 / 31 / 201613: 15$ & 43.2 & 80 & 80.4 & -0.36 & - \\
\hline $06 / 28 / 201612: 15$ & 89.2 & 168 & 157 & 10.5 & - \\
\hline 07/19/2016 14:45 & 23.9 & 52 & 48.0 & 4.01 & - \\
\hline 08/03/2016 13:15 & 36.8 & 75 & 69.6 & 5.38 & - \\
\hline 08/23/2016 12:30 & 26.8 & 72 & 52.9 & 19.1 & - \\
\hline 09/13/2016 13:15 & 22.5 & 46 & 45.6 & 0.36 & - \\
\hline $10 / 04 / 201612: 45$ & 22.2 & 58 & 45.1 & 12.9 & - \\
\hline $10 / 25 / 201613: 00$ & 88.5 & 150 & 156 & -6.32 & - \\
\hline 02/22/2017 13:00 & 35.0 & 39 & 66.6 & -27.6 & - \\
\hline 05/10/2017 12:45 & 30.5 & 42 & 59.1 & -17.1 & - \\
\hline $06 / 06 / 201712: 30$ & 14.4 & 27 & 32.1 & -5.06 & - \\
\hline 06/21/2017 11:30 & 14.2 & 28 & 31.7 & -3.73 & - \\
\hline 07/20/2017 11:00 & 31.1 & 144 & 60.1 & 83.9 & - \\
\hline 08/11/2017 12:00 & 42.2 & 50 & 78.7 & -28.7 & - \\
\hline 08/30/2017 12:15 & 11.3 & 12 & 26.9 & -14.9 & - \\
\hline 09/20/2017 10:45 & 78.9 & 70 & 140 & -70.2 & 一 \\
\hline
\end{tabular}

Date model was created: November 28, 2018

Model application date: February 22, 2017, onward

Analyzed by Daniel Livsey, CAWSC, November 28, 2018

Approved by Maureen Downing-Kunz, CAWSC, November 29, 2018 


\section{Model Summary for Suspended-Sediment Concentration at Station 373015122071000 South San Francisco Bay at Dumbarton Bridge, Calif., Elevation of 12.5 Meters Below Mean Lower Low Water ("Lower")}

The regression model is based on 32 paired measurements of suspended-sediment concentration against concurrent turbidity samples collected from February 12, 2015, through September 20, 2017. Values outside of regression diagnostic criteria ranges (table 1.58) were flagged (table 1.59) and investigated as potential outliers.

The final regression analysis to estimate suspended-sediment concentration at site number 373015122071000 "lower" resulted in the following model:

$$
S S C=4.02 \times T U R B^{0.821}
$$

The data and analyses used to develop the suspended-sediment concentration model for this site are summarized in tables and figures in this section (tables 1.55 to 1.60 ; figs. 1.37 to 1.40 ).

Table 1.55. Previous and current suspended-sediment concentration model for station 373015122071000, South San Francisco Bay at Dumbarton Bridge, Calif., at an elevation of 12.5 meters below mean lower low water (“lower”). Model coefficient computed as 10 raised to the intercept multiplied by the bias correction factor.

[SSC: suspended-sediment concentration in milligrams per liter (80154); TURB: turbidity in formazin nephelometric units (63680)]

\begin{tabular}{cll}
\hline Start date & \multicolumn{1}{c}{ End date } & \multicolumn{1}{c}{ Model } \\
\hline Oct. 01, 2015 & Sept. 30, 2016 & $\mathrm{SSC}=7.73 \times \mathrm{TURB}^{0.714}$ \\
Oct. 01, 2016 & Ongoing & $\mathrm{SSC}=4.02 \times \mathrm{TURB}^{0.821}$ \\
\hline
\end{tabular}
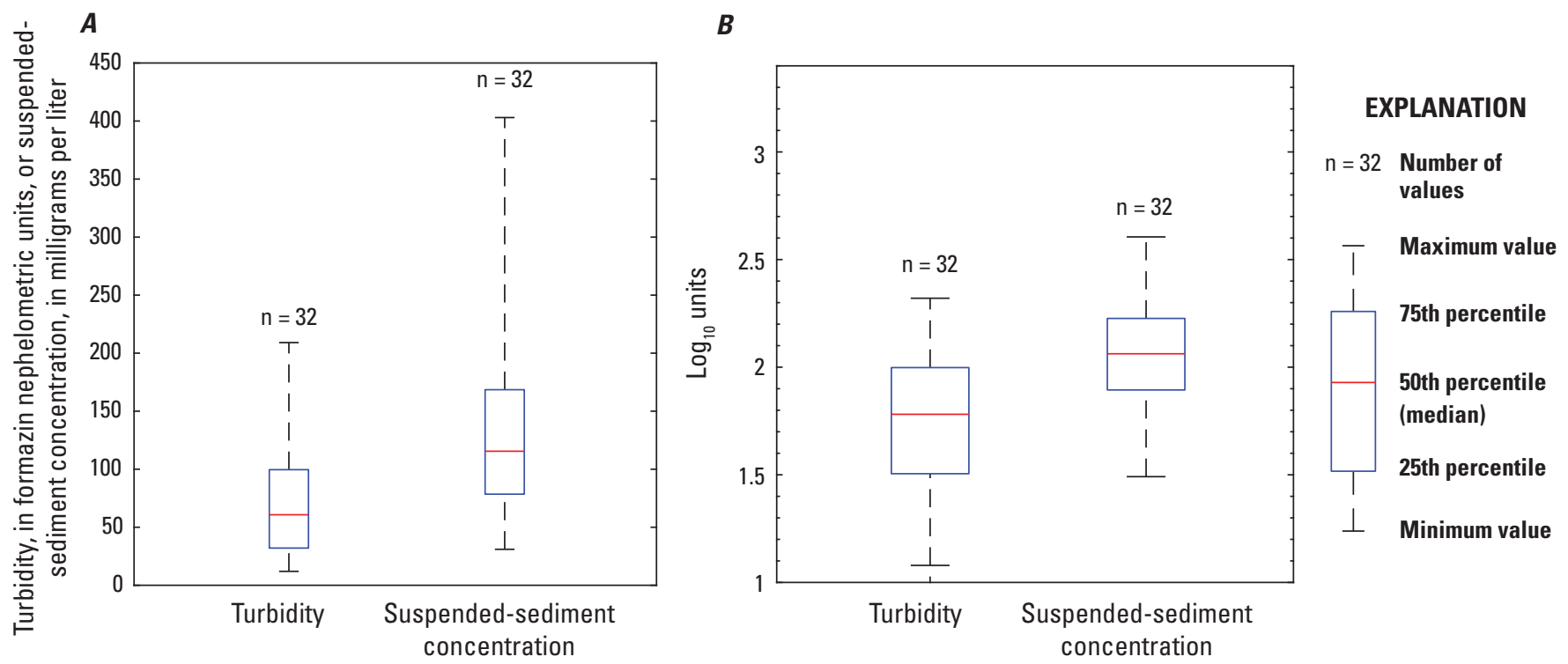

Figure 1.37. Distribution of model variable values for data from station 373015122071000 , South San Francisco Bay at Dumbarton Bridge, Calif., elevation of 12.5 meters below mean lower low water (“lower") in $A$, linear units, and $B$, log-transformed units. Data from February 2015 to September 2017 were used. 
$\boldsymbol{A}$

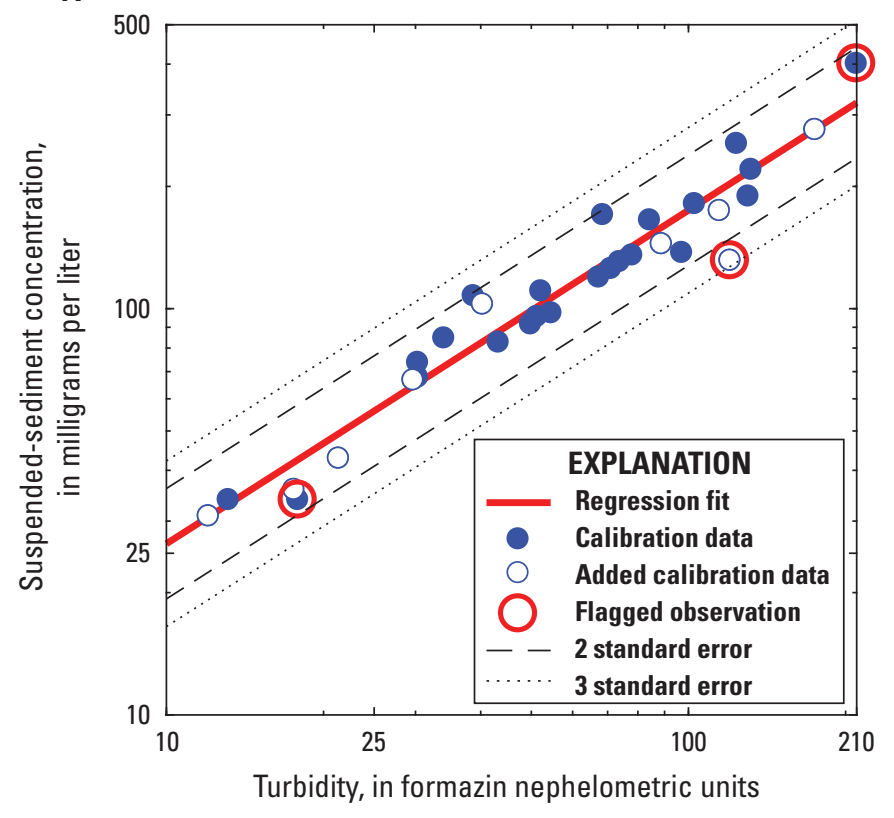

C

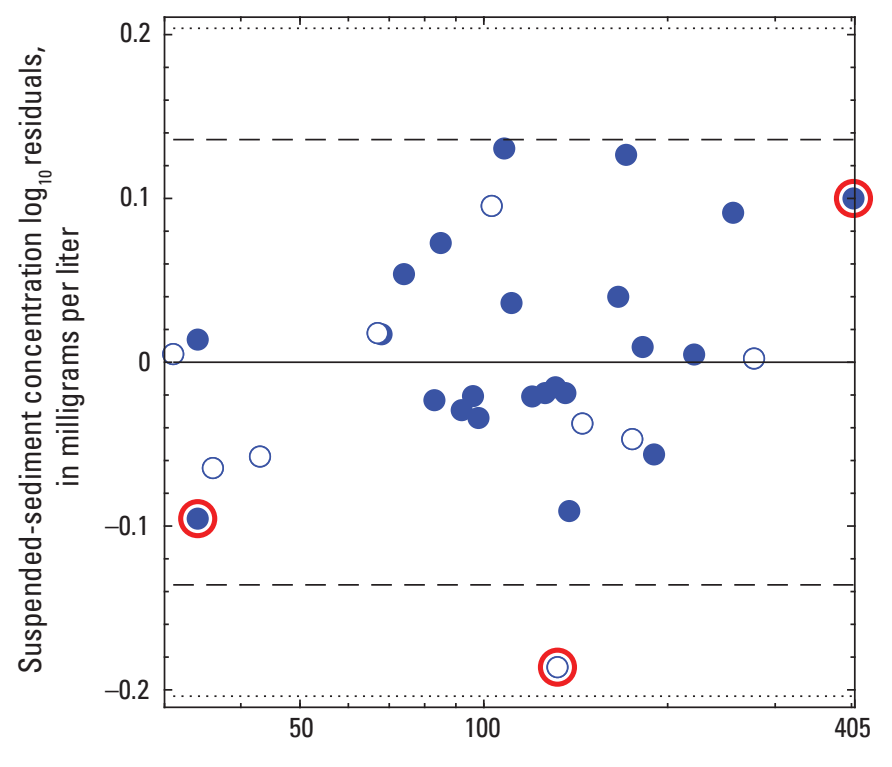

Suspended-sediment concentration, in milligrams per liter

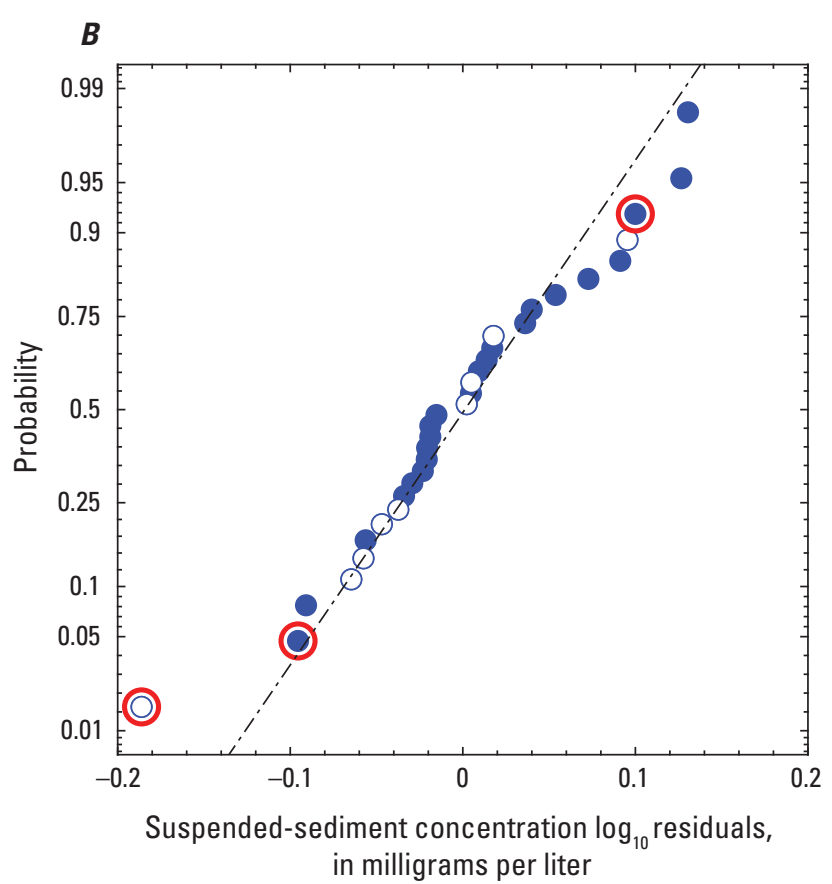

D

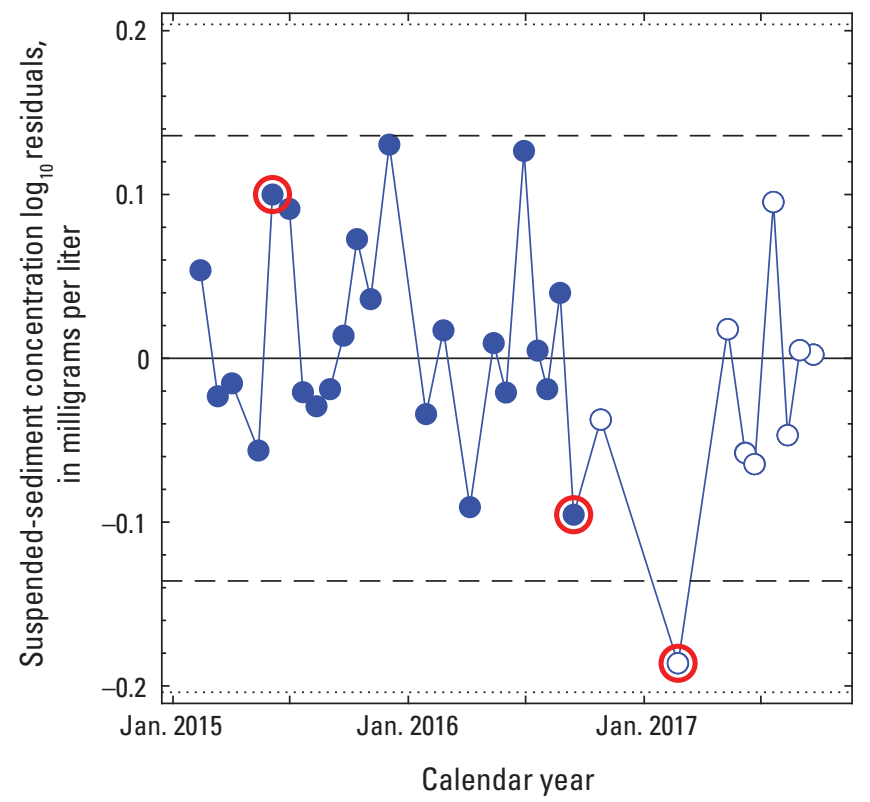

Figure 1.38. Assessment and analyses of model data for station 373015122071000, South San Francisco Bay at Dumbarton Bridge, Calif., at an elevation of 12.5 meters below mean lower low water ("lower"): $A$, model calibration data and regression; $B$, normal quantile plot of model residuals; $C$, model residuals plotted against suspended-sediment concentration (SSC); and $D$, model residual time series. Data from February from 2015 to September 2017 were used. 


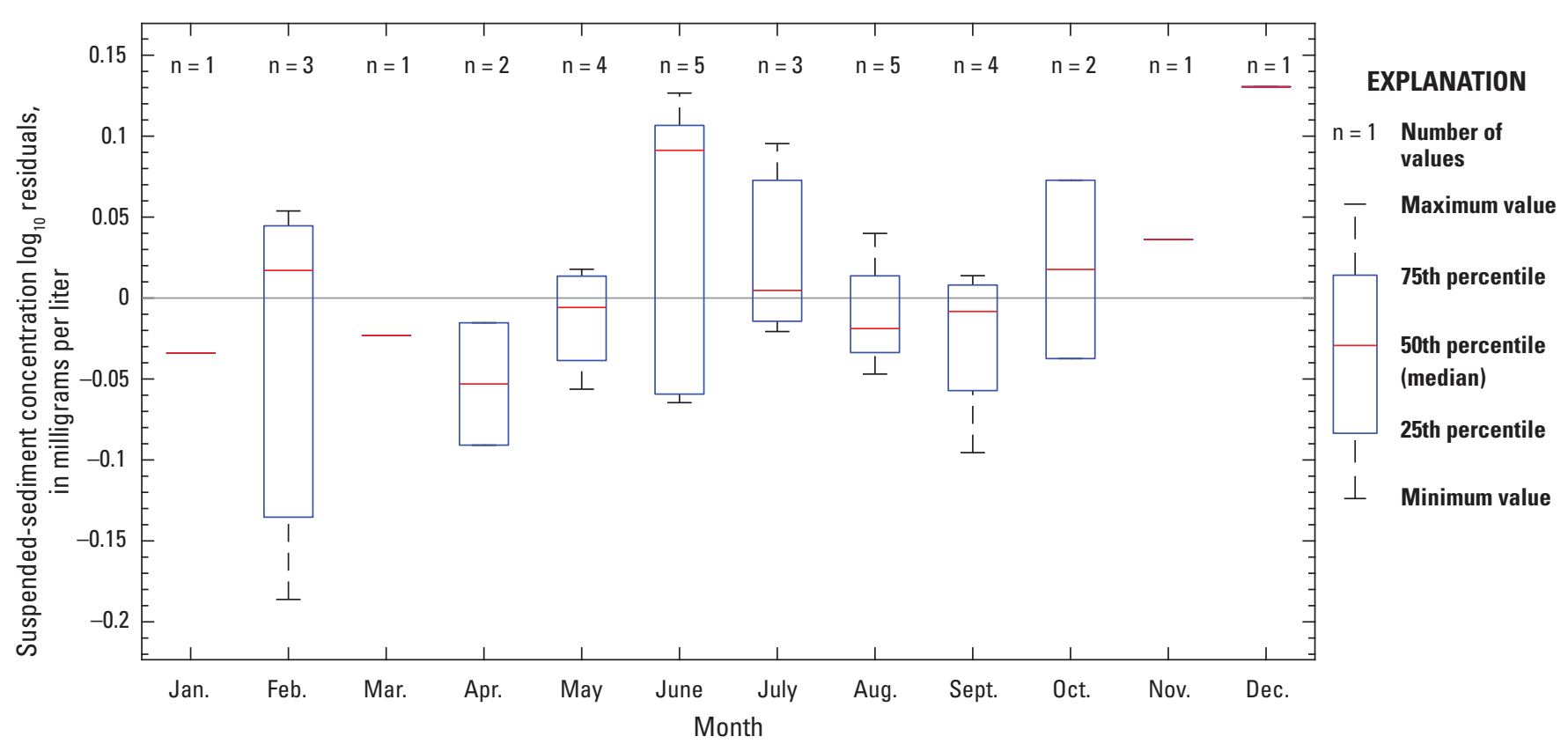

Figure 1.39. Distribution of model residuals by month for station 373015122071000, South San Francisco Bay at Dumbarton Bridge, Calif., at an elevation of 12.5 meters beow mean lower low water ("lower"). Data from February from 2015 to September 2017 were used.
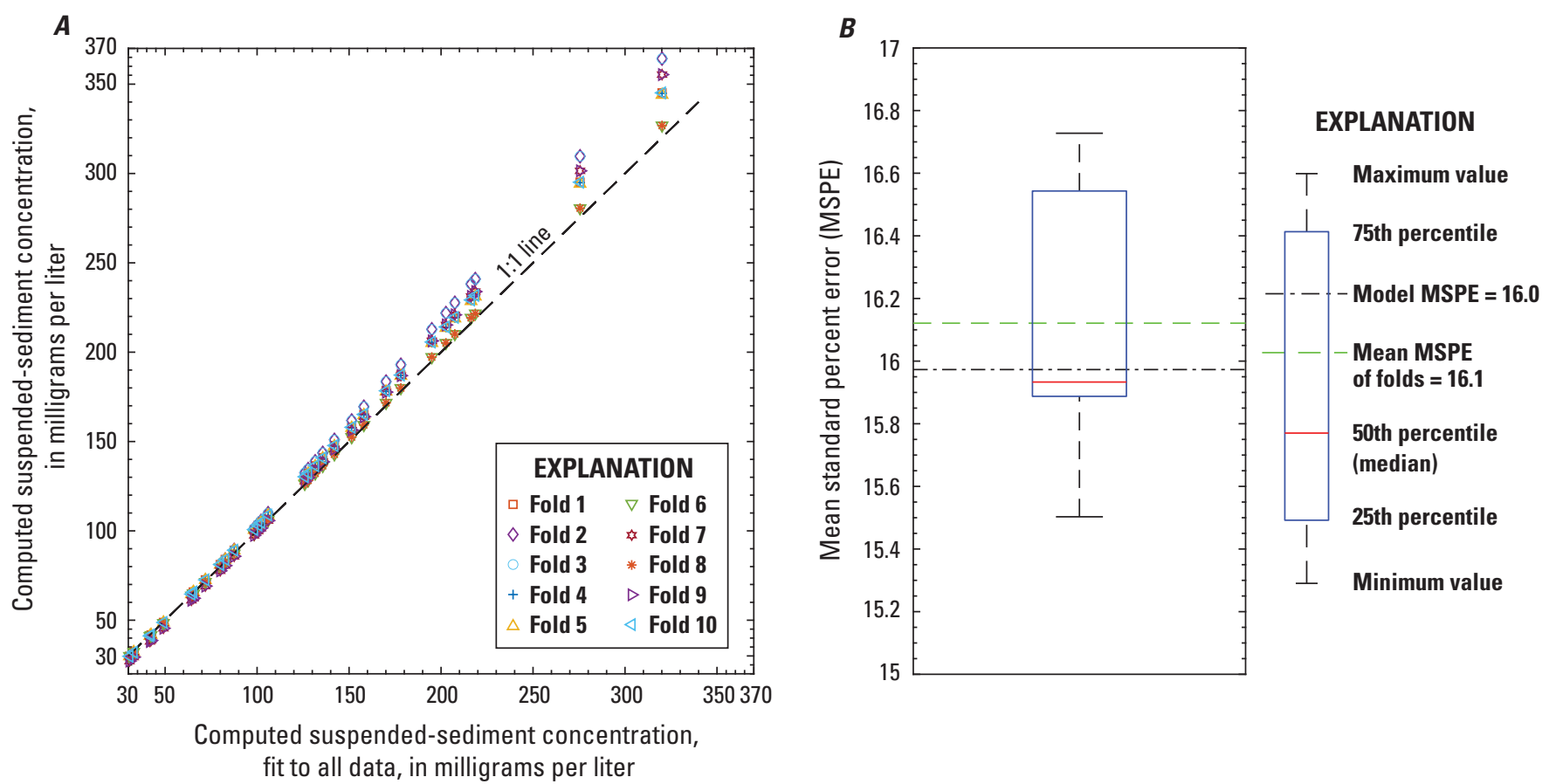

Figure 1.40. Cross-validation of model using varying subsets of for data from station 373015122071000, South San Francisco Bay at Dumbarton Bridge, Calif., at an elevation of 12.5 meters below mean lower low water ("lower"): $A$, computed suspended-sediment concentration (SSC) from cross-validation by model data subsets compared to SSC computed from model fit to all data; $B$, distribution of cross-validation subset mean standard percent error (MSPE) compared to MSPE of model fit to all data. Data from February from 2015 to September 2017 were used. 


\section{A Summary of Water-Quality Monitoring in San Francisco Bay in Water Year 2017}

Table 1.56. Basic regression statistics for data from February 2015 to September 2017 at station 373015122071000 , South San Francisco Bay at Dumbarton Bridge, Calif., at an elevation of 12.5 meters below mean lower low water ("lower").

\begin{tabular}{lc}
\hline \multicolumn{1}{c}{ Number of observations } & $\mathbf{3 2}$ \\
\hline Standard error (RMSE) & 0.07 \\
Model standard percentage error (MSPE) & 16.0 \\
Coefficient of determination $\left(\mathrm{R}^{2}\right)$ & 0.94 \\
Adjusted $\mathrm{R}^{2}$ (Adj. $\mathrm{R}^{2}$ ) & 0.94 \\
\hline
\end{tabular}

Table 1.58. Flagged observation criteria for data from February 2015 to September 2017 at station 373015122071000 , South San Francisco Bay at Dumbarton Bridge, Calif., at an elevation of 12.5 meters below mean lower low water ("Iower").

[Cook's D, Cook's distance; \pm , plus or minus]

\begin{tabular}{cccc}
\hline Studentized residual & Leverage & Cooks' D $^{\prime}$ & DFFITS \\
\hline \pm 3 & 0.19 & 0.10 & 0.50 \\
\hline
\end{tabular}

Table 1.57. Explanatory variables, coefficients, and statistics for selected regression model for data from February 2015 to September 2017 at station 373015122071000, South San Francisco Bay at Dumbarton Bridge, Calif., at an elevation of 12.5 meters below mean lower low water ("lower").

$[-$, no data $]$

\begin{tabular}{lcccc}
\hline \multicolumn{1}{c}{ Variable } & Coefficient & $\begin{array}{c}\text { Standard } \\
\text { error }\end{array}$ & t-value & p-value \\
\hline Intercept & 0.600 & 0.07 & 8.87 & $6.92 \mathrm{E}-10$ \\
Slope & 0.821 & 0.04 & 21.5 & $8.78 \mathrm{E}-20$ \\
Bias correction & 1.01 & - & - & - \\
$\quad$ factor (BCF) & & & & \\
\hline
\end{tabular}

Table 1.59. Flagged observations for data from February 2015 to September 2017 at station 373015122071000, South San Francisco Bay at Dumbarton Bridge, Calif., at an elevation of 12.5 meters below mean lower low water ("lower").

[mm/dd/yyy, month/day/year; hh:mm, hour:minute; FNU, formazin nephelometric units;

SSC, suspended-sediment concentration; mg/l, milligrams per liter; Cook's D, Cook's distance]

\begin{tabular}{lcccccc}
\hline $\begin{array}{c}\text { Time } \\
\text { (mm/dd/yyyy hh:mm) }\end{array}$ & $\begin{array}{c}\text { Turbidity } \\
\text { (FNU) }\end{array}$ & $\begin{array}{c}\text { SSC } \\
\text { (mg/l) }\end{array}$ & $\begin{array}{c}\text { Studentized } \\
\text { residual }\end{array}$ & Leverage & Cooks' D & DFFITS \\
\hline 06/04/2015 08:30 & 209 & 403 & 1.59 & 0.13 & 0.19 & 0.62 \\
09/13/2016 13:00 & 17.8 & 34 & -1.49 & 0.11 & 0.13 & -0.51 \\
$02 / 22 / 201713: 15$ & 120 & 132 & -3.18 & 0.07 & 0.27 & -0.84 \\
\hline
\end{tabular}


Table 1.60. Model-calibration dataset for data from February 2015 to September 2017 at station 373015122071000, South San Francisco Bay at Dumbarton Bridge, Calif., at an elevation of 12.5 meters below mean lower low water ("lower").

$[\mathrm{mm} / \mathrm{dd} / \mathrm{yyy}$, month/day/year; hh:mm, hour:minute; FNU, formazin nephelometric units; SSC, suspended-sediment concentration; mg/l, milligrams per liter; - , no data]

\begin{tabular}{|c|c|c|c|c|c|}
\hline $\begin{array}{c}\text { Time } \\
\text { (mm/dd/yyyy hh:mm) }\end{array}$ & $\begin{array}{l}\text { Turbidity } \\
\text { (FNU) }\end{array}$ & $\begin{array}{l}\text { SSC } \\
(\mathrm{mg} / \mathrm{l})\end{array}$ & $\begin{array}{c}\text { Computed SSC } \\
(\mathrm{mg} / \mathrm{l})\end{array}$ & $\begin{array}{c}\text { Residual } \\
\text { (mg/l) }\end{array}$ & $\begin{array}{c}\text { Censored } \\
\text { value }\end{array}$ \\
\hline $02 / 12 / 2015$ 14:30 & 30.2 & 74 & 66.0 & 8.02 & - \\
\hline 03/11/2015 12:00 & 43.1 & 83 & 88.4 & -5.35 & - \\
\hline 04/02/2015 11:30 & 73.5 & 131 & 137 & -5.94 & - \\
\hline 05/13/2015 13:00 & 130 & 190 & 219 & -28.7 & - \\
\hline 06/04/2015 08:30 & 209 & 403 & 323 & 80.0 & - \\
\hline $06 / 30 / 201513: 15$ & 123 & 256 & 209 & 47.0 & - \\
\hline 07/21/2015 13:00 & 51.1 & 96 & 102 & -5.61 & - \\
\hline 08/11/2015 13:45 & 49.7 & 92 & 99.3 & -7.32 & - \\
\hline 09/01/2015 13:00 & 70.8 & 126 & 133 & -6.80 & - \\
\hline 09/22/2015 13:00 & 13.1 & 34 & 33.2 & 0.76 & - \\
\hline 10/13/2015 12:00 & 33.9 & 85 & 72.5 & 12.5 & - \\
\hline $11 / 03 / 2015$ 15:00 & 50.2 & 111 & 103 & 7.92 & - \\
\hline $12 / 02 / 201514: 00$ & 38.6 & 108 & 80.7 & 27.3 & - \\
\hline 01/28/2016 14:00 & 54.4 & 98 & 107 & -8.97 & - \\
\hline 02/24/2016 13:15 & 30.2 & 68 & 66.0 & 2.02 & - \\
\hline 04/05/2016 14:45 & 96.8 & 138 & 172 & -33.7 & - \\
\hline 05/12/2016 12:30 & 102 & 182 & 179 & 2.78 & - \\
\hline 05/31/2016 13:00 & 67.1 & 120 & 127 & -7.08 & - \\
\hline $06 / 28 / 201612: 30$ & 68.3 & 171 & 129 & 42.1 & - \\
\hline 07/19/2016 14:30 & 131 & 221 & 220 & 0.91 & - \\
\hline 08/03/2016 13:00 & 77.7 & 136 & 143 & -7.34 & - \\
\hline 08/23/2016 12:15 & 84.0 & 166 & 153 & 13.2 & - \\
\hline 09/13/2016 13:00 & 17.8 & 34 & 42.7 & -8.75 & - \\
\hline $10 / 25 / 201613: 15$ & 88.5 & 145 & 160 & -14.5 & - \\
\hline 02/22/2017 13:15 & 120 & 132 & 205 & -72.8 & - \\
\hline 05/10/2017 13:00 & 29.6 & 67 & 64.9 & 2.10 & - \\
\hline 06/06/2017 12:45 & 21.3 & 43 & 49.5 & -6.54 & - \\
\hline 06/21/2017 11:45 & 17.5 & 36 & 42.2 & -6.16 & - \\
\hline 07/20/2017 10:45 & 40.2 & 103 & 83.4 & 19.6 & - \\
\hline 08/11/2017 11:45 & 114 & 175 & 196 & -21.4 & - \\
\hline 08/30/2017 12:00 & 12.0 & 31 & 30.9 & 0.07 & - \\
\hline 09/20/2017 11:00 & 174 & 277 & 278 & -0.85 & - \\
\hline
\end{tabular}

Date model was created: November 26, 2018

Model application date: October 1, 2016, onward

Analyzed by Daniel Livsey, CAWSC, November 26, 2018

Approved by Maureen Downing-Kunz, CAWSC, November 29, 2018 


\section{References Cited}

Helsel, D.R., and Hirsch, R.M., 2002, Statistical methods in water resources: U.S. Geological Survey Techniques and Methods, book 4, chap. A3, https://doi.org/10.3133/twri04A3.

Rasmussen, P.P., Gray, J.R., Glysson, G.D., and Ziegler, A.C., 2009, Guidelines and procedures for computing time-series suspended-sediment concentrations and loads from in-stream turbidity-sensor and streamflow data: U.S. Geological Survey Techniques and Methods, book 3, chap. C4, 53 p., https://doi.org/10.3133/tm3C4.
U.S. Geological Survey, 2016, Policy and guidance for approval of surrogate regression models for computation of time series suspended-sediment concentration and loads: Office of Surface Water Technical Memoranda 2016.07 and 2016.10, 40 p., https://water.usgs.gov/admin/memo/SW/ sw.2016.07+wq.2016.10.pdf.

U.S. Geological Survey, 2019, National Water Information System: U.S. Geological Survey Web interface, https://doi.org/10.5066/F7P55KJN. 
For more information concerning the research in this report, contact the Director, California Water Science Center

U.S. Geological Survey

6000 J Street, Placer Hall

Sacramento, California 95819

https://ca.water.usgs.gov

Publishing support provided by the U.S. Geological Survey Science Publishing Network, Sacramento Publishing Service Center 

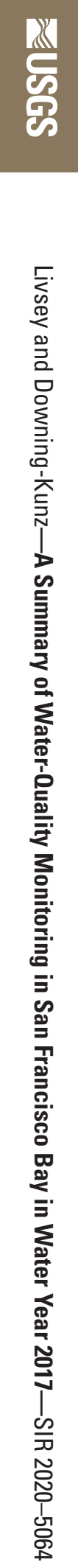